(T)

Why

(1)

is

Wint

sitho

1) 10 mon

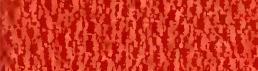

Wh 7 on

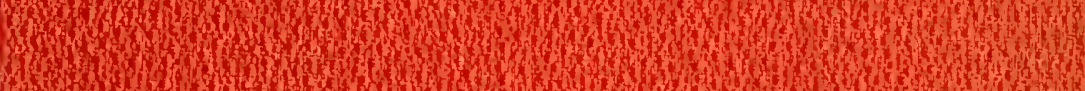

1.

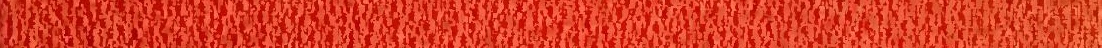

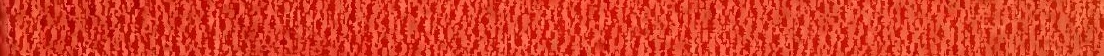

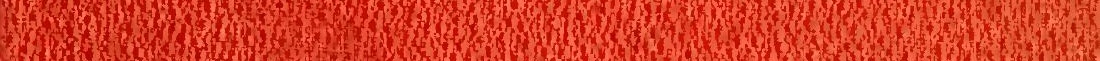
19.

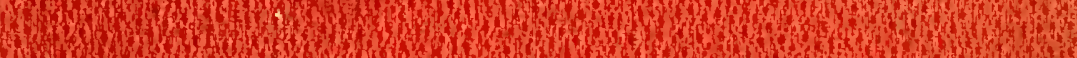
15.

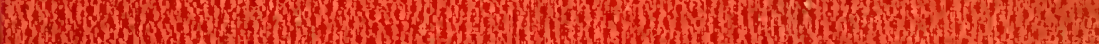

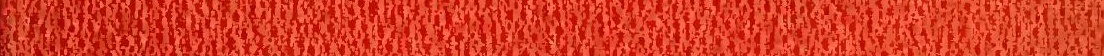

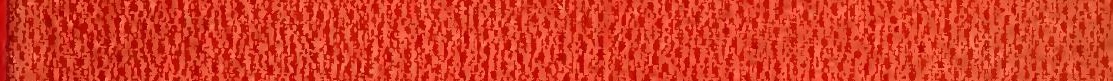
15 3. 14.

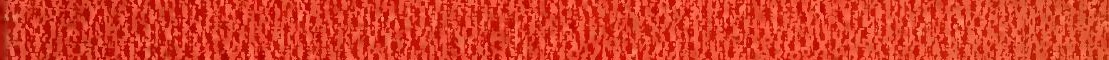

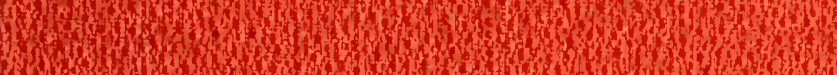

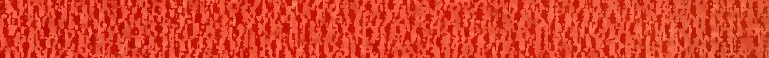

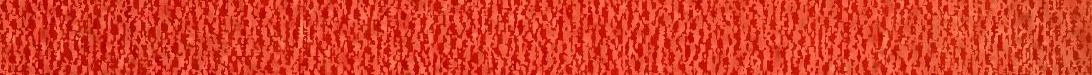

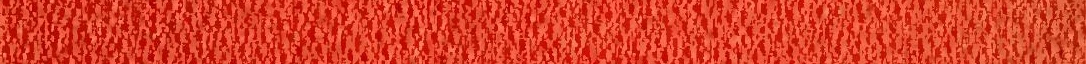

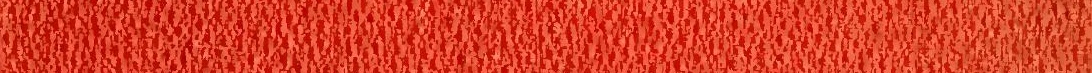
107

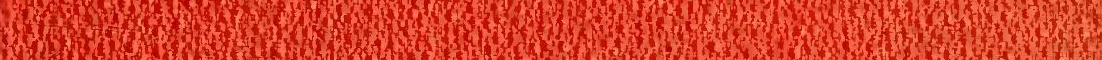

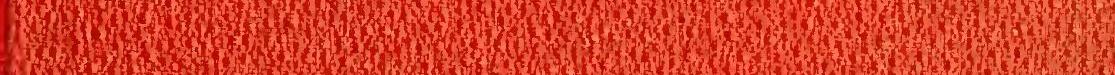
How

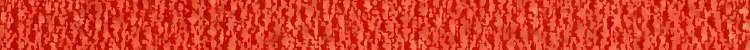

5

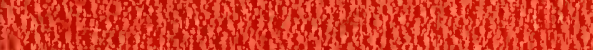

8

505

13.

T58 


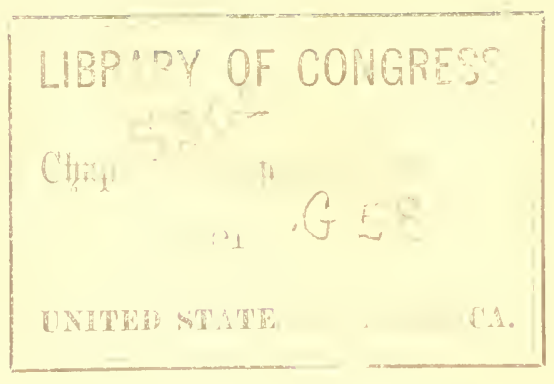








\section{PRACTICA L}

\section{FARMER'S GUIDE}

WRITTEN BY

\section{E. P. GODLEY.}

OF BURKE COUNTY. GA.

REVISED BY

HON. WALTER A. CLARK,

OF RICHMOND COUNTY.

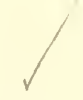

AUGUSTA. GA.

JAS. L. GOW, BOOK AND JOB PRINTER.

1871. 
Fintered according to Act of Congress, in the year 1871, by E. P. GODLEY,

in the (Iffice of the Librarian of Congress, at Washington. 


\section{P R E F A E.}

The Author's design, in the preparation of the following pages for the press, has been to furnish in a convenient form a plain and practical Manual for the cultivation of all the leading staples of the Soutb, with a variety of information upon other and kindred subjects, dednced from his own lengthy experience and an attentive observation of the practice of suceessful planters in nearly all of the Southern States.

The loss of so large a number of practical farners by the easualtics of the late war, and the increasing immigration of numbers from other sections who are entirely unacquainted with our system and nodes of culture, seems to him to have created a special necessity for such a work, at this time.

There are other publications of a somewhat similar character of eminent merit, but none, he thinks, sufticiently comprehensive to meet the demands of the times. Influenced by these considerations, and at the solicitations of friends, he has prepared this work, and now presents it to the public, in the hope that it may be of some benefit, at least, to the young and inexperienced-perhaps to some of maturer years; that it may contribute, in some slight degree, to rebuild "the waste places" of his native South, and, by adding to her material prosperity, render some humble assistance in enabling her to recover her normal position in the laud-believing also, as he does, that "the Angel of Peace is the Sister of Agriculture, and the Flag of Empire will follow the track of the plow." 



\section{CONTENTS.}

PAGE.

Cultivation of Corn and sielection of Seed ............... 9

A successtul way to make Corn on any kind of Land.............

Cnltivation of Sbort Staple Cotton................... 14

Diagram of the Dibble, and Explanation of its use............20

Cultivation of Sea Island Cotton-Long Staple .............21

Cultivation of Low Land Golden Rice...................22

Cultivation of Upland Rice...........................

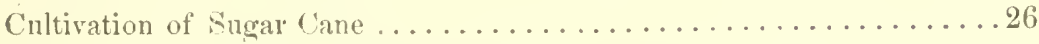

Wheat and its Culture. By Jurge Smith, of Jefferson County, Ga.....28

Cultivation of Oats.............................. 29

Cultivation of Rye........................

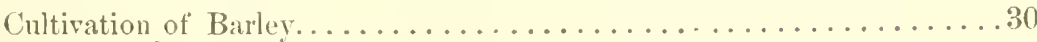

Cultivation of Bnckwheat ......................... 30

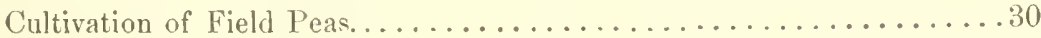

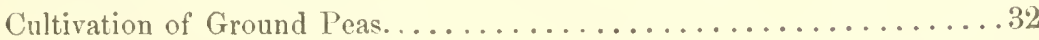

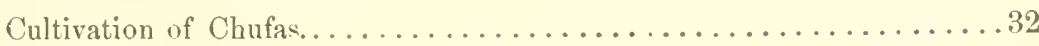

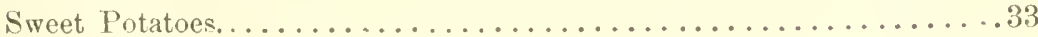

The Best Method of Saring Sweet Potatoes. By George T. Cogel, of

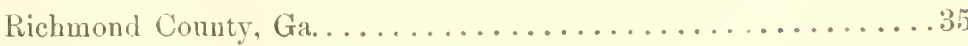

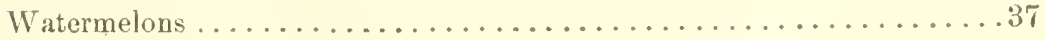


Muskmelons and Cantelopes ....................... 10

Cirowing Watermelons. By Judge Sinith, of Jefferson County, Ga....41

A Good Fertilizer for Melons . . . . . . . . . . . . . . . . . 41

Kitchen Garlens............................ 42

Herbs ...............................

Syrup of Sarsaparilla and (2neen's Delight Componnd............46

Cultivation of Buncombe Large White Winter Cabbage...........46

Cuba smoking Tobacco.........................49

Chewing Tobace . . . . . . . . . . . . . . . . . . . . 51

Gnltivation of Grapes. By W. T. Killingsworth, of Richmond Co., Aa. .52

Peach Culture. " " "

Apple Culture. " " " " " "

Strawberries.

Peach Culture. By Joseph Saxon, of Richmond Connty, Ga........555

Rai-ing Hay in the sonth . . . . . . . . . . . . . . . . . 56

Hoe Culture and its Advantages. .................. 56

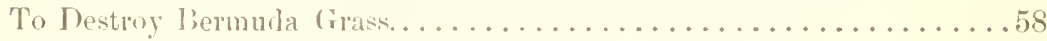

A Plan to Economise Time and Labor...................59

Diagram of Circle, and Explanation of the Mfode of Cultivation.....66

IIints on Farm Builelings.......................... . . .

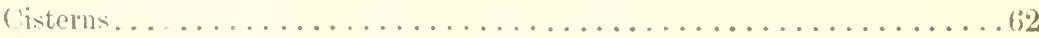

On the Raising of Fowk..........................

Raising Horses in the fonth . . . . . . . . . . . . . . 64

Hog Raising in the south . . . . . . . . . . . . . . . . 65;

Cattle Raising at the Sontl.....................66

Sheep ................................. 6 \%

Productions of feor ia.......................... 67

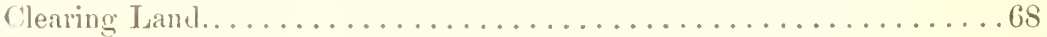

Lotation ef Crops............................. 69

The Different Speeies of Lands in the Southern States, and their Peculiarities . ................................ 
Bee Husbandry............................... 73

Large, Deep, Open Ponds.......................... 75

On Fences...................................... 77

Porcelain Clay Hill in Richmond Cousty, Ga................ 80

On the Production of Turpentine....................... 80

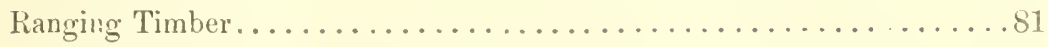

Guano and Fertilizers generally...................... 8.

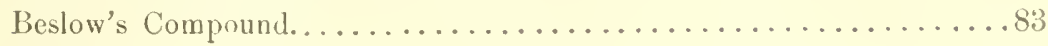

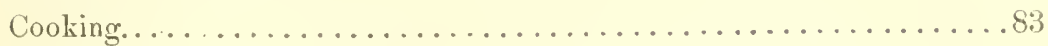

General Intormation.......................... 85

Planting Cotton by Machine....................... 87

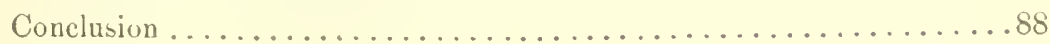





\section{THE CULTIVATION OF CORN,}

AND SELECTION OF SEED TO MAKE IT PROLIFIC.

Break up your land deep with steel turning plows, and subsoil with plows that will cut as wide as the turn plow, to have it thoroughly broken. Arrange the subsoil plow so that the dirt will fall back into its proper place, where nature intended it to be. If the land has a elay foundation, break up twelve to fifteen inches deep, fill the earth with vegetable matter, haul in straw and leaves, and turn them nnder in November. Manme high and plant deep for corn and cover shallow. Mill ponds reclaimed for cultivation, bay lands, light, sandy hammocks on the sea coast, the islands adjacent, cow-hide lands, and very broken lands-these six kinds should never be subsoiled. There is no rule without exceptions. Break up such lands deep with one-horse turning plow. The deeper land is broken, the deeper it should be fertilized, to emrich the yellow dirt and deepen the soil. Break up the land in December and November, to mix the soil and make it retain moisture. Broom sedge fields should be broken up eally, to destroy cut worms and bugs; and harrowed, to tear the turfs to pieces and submit them to the winter frosts. Prepare the land early and plant early. Never break nor plant land when very wet. It will injure land, and more particnlarly when stiff and disposed to run together after a hard rain. Breaking up land is hard work; the horses should be allowed to walk slowly, else the planter may break them down in the spring, to the serious inconvenience of the after crop. A good farmer should always be able to rest his hor'ses a few days after breaking up the land. 'T'o let them have the run of a rye patch, then, will more than repay the tritling expense; for then, should it be found necessary to push them in the after erop, they will be able to stand it. But a horse that has become poor in the spring, if he does not entirely fail in summer, will often be unable to do a balf day's work when there is the greatest need. It is imposible either to fatten them in the heat of summer, or to keep an extra number, for hor'ses are too expensive in a land where neither elover nor blne grass are raised. Very few Southern planters sow much small grain, or raise even enough to do them. For several years before the last war, and since, they have depended almost entirely on the Western and Northern markets for corn and meat. In $1866^{\circ}$ and 1867 , many of the largest planter's in Burke cunnty, Ga, planted very little corn, selecting their poorest land for this crop, as they could bny Western corn cheaper than they conld raise it. This is poor economy. Every planter ought to raise his own corn and meat. And two poor horses will consume as mnch corn and fodiler as three fat ones. On the other hand, two fat horses will do the work of three poor ones. Therefore, each planter, if he wonld grow rich, must not pay out the money he makes on cotton in buying corn. He ought to raise enough of the one to support the other. The idea of a big cotton crop and little corn is erroneous. But to return to our subject. When the corn land is ready, lay off your rows six feet wide with a turned shovel or a small turning plow. Plant deep in the ground, but 
cover shallow. If you have good stalle manure, guano, or eotton seed plant three feet apart; if gom have neither, furre feet hy six in the drill. This will Jeave a good distance and room for pras. l'ant two grains in a hill, for it is better to thin ont than to replant, and replanted corn schlom makes more than halt a croj. Com slumbl he planterl as cauly as possilule in Middle Georgia and other similar batitudes. The last of folmoury is lloe lest time. There are several advantages in an early erop: it makes more and better corn, and leaves extra time for cultivation of cotton-mu mean consideration, when eotom is thirty eents a poumd. 'The extreme heat of summer is unfarorable to the matming of this crop, and it slombl be well advanced before this comes on. Be sure to solect arood gombl secel eorn : then, for every buslael of eorn, mix me qualt of enal tal with one gallon of boiling water, stimg the mixture thoromghly. 'Then, when it has loceme blood warm, put in the eorn. Stir the eorn mut every uran lowks as if it had been valuished, aldeling soot enomets to make it drop easily. The eoal tar is very bitter, and so is the sont and this mixtmere not only protects the seed from wet and colel, lut from inserts and birds; aets is a tertilizer, making the young plant stong and healthy, and preventing its deeay. Coal tar ean be purchased at the gas workin for alumt twouty cents a gallon. I

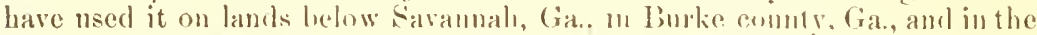

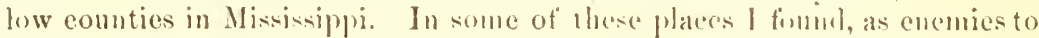
the crop, rats, mice, crows, jacklaws, and ofler birks. But not one of them would trouble com soraked in this solution. Many piec planters use it to save bird minling. It is lecter than shonghg the hirls, for they are valuable in the destriction of insects and worms. It is better llan poisoning, for that is sometimes dangeroms.

The furrows shond be lail uff holl ways-that is, cheeked, so as to have

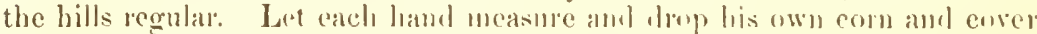
with his foot. The homan fuot eorers helter hlan hore, harrow or seooter plow, for each of these tools is apt to move the gran and plant it tou deep. Next to the foot the forked seonter is lest. On rivel swanp lands sow corn very thick in the drill as you would cotton, and a few days hefire it eomes up run a harrow over the eor'n, to take off the ermst and some of the dirt, for fear the com may he cowerenl too deop, amblalso to level the gromml. As

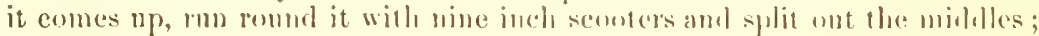
then love and laves two stalke in a liall two teet apart. Jelay thiming as

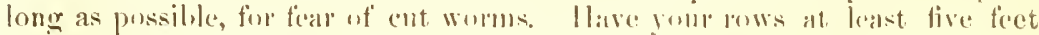
apart, to insure sutliejent sum and ail. Even river lamble require distance one

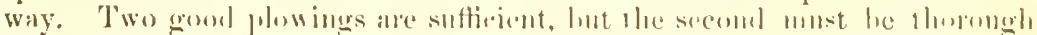

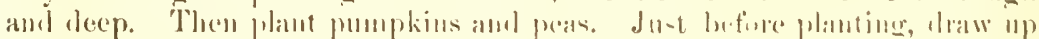

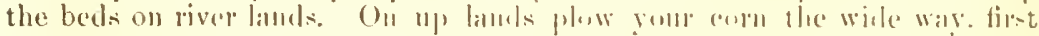

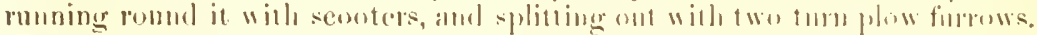
When you plow the second time, plant peris and split ont all the midlle

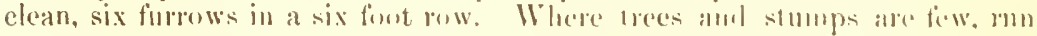

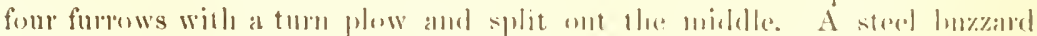

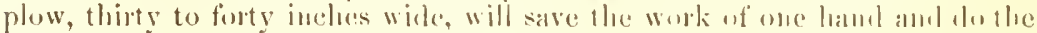
work better. For the third pluwing, rmo twiee in a row will twenty-two

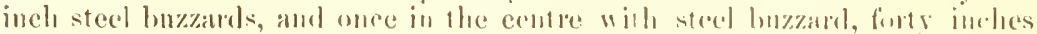

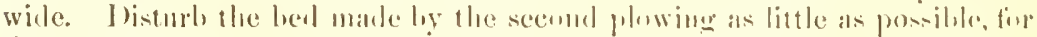

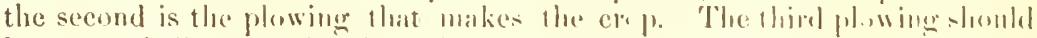

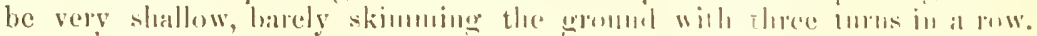
Next hill, giving a good hill, and dawing the suil to the eorn from a dis- 
tance of at Irast a foot and a half around. Chupping close to the eorn does

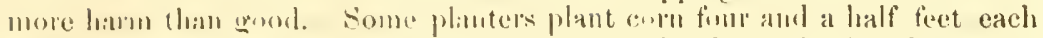
way and plow each way. Ollers plant five feet by thee, plowing the narrow way the first and second times, and the third time the wide. Some planters use seoulders alone; some beak up with seonters and fonish with buzzards. Where lands are stiff and liable to mu together, this is the better mosle of cultivation; but where the suil is guod and plenty of manme, it will require

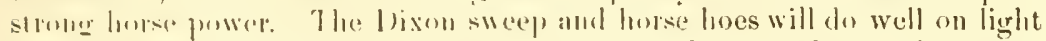

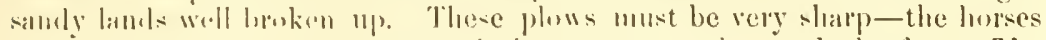

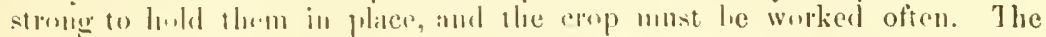
fichl shonld le thoronghly hoken and leveled for all kinds of plows: therely the elop is nore aidy cultivited, the soil more evenly mixed. the molsture better retaisul, the rows laid ofl more evenly. Th" plant new gromml, sumter up buth ways; lay off the rows tive of six feet apalt one way, two or thee fiet the other. Make a bole in the hill with a grubbing hoce, and plant thre or form grains in a hill-sufteient fior a good stand. Plant deep-just after a lain, if prosible; cover shallow. The second time plow on luth sides of your corn and plant peis. My own plan for Middle Cieorgia is, to plant six feet by thee, if the lamel is mammed; if not, six by three and a half. To plant deep and cover slablow. The first plowing $\mathrm{I}$ run round the corn with nine inch seouters, leep, and two furrows. The second phwing I turn four furmes to the row with turn plows, and split ont the centre whih forty inch strel buzard, very sharj and flat. This saves the labor of ane hamd, splits ont the millle that wonld require three furrows of a turn plow, and leaves the land in better state for third plowing. For third plowing, run twice in a row with a twenty-two inch stecl buzzard, and once with a two-horse buzzarel.

Corn should always be planter in good time; for if it gets stunted from not being worked in scason, it ean never be sufticiently recovered to make a good crop. In this respect corn and cotton ditter, for if cotton gets grassy you can work it ont snceessfully. A few days atter third plowing, hoe the corn orer and hill it, drawing in the dirt some listance from the stock, making a good tlat liill. Drillow eorn ran be made with less work. My plan is eitlier to plow twice with nine furrows, or three times with twolve; with good lurses and plows, and not too large a crop, with ten furrows. If the land is well broken and harmwed, run round the corn with scooters and plow ont all the midlle at second plowing. I once made a good crop with seren furrows, on the plantation of A. J. Lawson, in Burke. I broke up the laud rery deep, and mannenl rery highly with cotton seed. The first plowing I ran rombl the corn twice to a row. That year I had a heary cottun crip, and before I could get to the second pluwing, owing to the deep tillage, the manure and frequent rains, the corn was waist high and very grassy. I plowed it ont clear, four furrows with turn plow and one with two forse buzzard. It was ruming some risk, but it rained several days after and the corn did unt fire, so that I suceeded. Some three weeks after I hilled it and mate a fine erop.

I will now give my reasoms why it is lest to dibll corn. I have said it can be male with less work, and ceomomy of labor is never a mean consideration. 'Then it is not so hand either to horse or ploughum to walk on level gromul. If you plant in the hill and plow botli ways, the horse and plow. inan must wailk on high beds. It takes almost donble the plowing to cultivate eorn in hills. Some do so to save hocing, but if the land be well 
broken and hanowed it will need no hoeing. Take all hands some day, when it is too wet to plow, and use long padiles, and the crop can he thinned in a short time. Drilled corn should always be plowed with a two-horse steel buzzard in the centre of the row. Never make a ditch in the middle of a corn row. Leave a small hed, and never split ont clean with a turn plow. 'To procure good seed corn, select first yonr brag field-one that has not suffered for want of cultivation or rain. "Then choose five acres, the very best. After the first killing frost, when the corn is ripe enough to be pulled, select those stalks which have the largest ears, and two to a stalk. No matter whether it be top or bottom ear, always take the largest. Procure your seed in this manner every year until the corn begins to overshoot like the Baden corn. In that ease, select your seed only every other year. Never plant white and yellow corn in the same field; they will mix, and the purer the seed the better. Plant gourl seed corn on the salts, and in two years it will change to tlint. Plant flint corn a hundred miles above Savannah and it will turn to gourd seed, or be a mixture, only fit for stock. There are several kinds of yellow corn, and some planters say it will grow best on poor land. I cannot say from experience. I have generally planted gourd seed in the up-country and pure flint on the salts. Some planters bar off the corn stalks, throwing the bed into the centre to save two or three furrows. When they go to plant corn they plow up the stalks. I disapprove this plan, from the fact that the land is not more than half plowed. When you plow your corn the first time you are obliged to split out all the middles clean; and if the ground is very hard, scooters will bave to be used, making donble the labor. Again, some rows will be six feet wide, some five and some four; or they will be wide at one end and narrow at the other. It will take more furrows to the rowe Experience has taught me that corn is gained and labor saved by leveling the land and equalizing the soil, and this is hest done by breaking up across the rows and harrowing. The harrow should be made of tough, seasoned wool, four feet syuare, with forty iron teeth, about an inch square and twelve inches long, sharpened well at the points. This utensil will require two horses, and will harrow about ten acres per lay. 'The harrow has been heretofore but little used in the Southern States, from the fact that most planters planted so largely to the horse and hand that they found no time to harrow. But now that labor saving implements are in requisition, it will be found very useful, partienlarly in the cultivation of small grain. The cultivation of small grain has never been successful at the South, because the land was not properly prepared and the crop is generally sowed too late. 'This matter should lo looked into, for small grain is valuable not only for the hands and horses, but is a most excellent pasturage for stock.

I will now give another method of planting corn on second and third quality lands, wherever there are few stumps and trees. Dig up the stumps and cut the trees as near the surfare as possible. If near a eity it will pay to preserve both and sell for fuel. Rreak and harrow the land as level as possible. Lay off the rows six feet both ways, and plant from four to five grains in a hill. Put a half peck of stable manure or a quart of cotton seed to a hill. Plant deep and cover shallow. Planting six feet ly six leaves plenty of room for two horses to walk, and also for a crop of peas, and to split the row with thirty or forty inch steel buzzard, or with Jixon sweeps. Have the plows well sharpened, with short single trees. With a gang of scooters to split out the middles and side the eorn, it pays to run over the crop four 
times. Very few Southern planters have ever used good plows; they should run level and true and straight. Put manure in deep, and you cannot use too much. Most farmers use so little that the strength gives ont about the time the corn silks and tassels, making a large stalk and little corn. Some planters may object to six feet each way and prefer six feet by three and one stalk to the hill. But this wonld give only the same number of stalks in a field, and wonld not leave so much room for peas and free circulation of air, the coln is not so apt to be "scatter-grain" and rot, and it is not so hot to work ol pnll the fodder. Cover manure deep that it may retain moisture. If the planter euts a hay crop, wide rows will be another advantage, and he will have fewer bills to manure. In dry and hot weather corn should be billed only in the morning and evening-never in the heat of the day. If corn is badly eultivated, neglected, and not worked at proper times, there will be double quantity of rotten corn when you gather it. Where two stalks of corn are planted to the hill it is not neeessary to tie the fodder in bundles; it will eure nicely between the stalks, and this is an economy of time. Rotten fodder injures horses. In two-stalk corn, should one good stalk remain, better not replant the other. They should both be of one age. Lands broken up in December are less apt to be troubled with cut worms. They are generally most troublesome on lands which have been lying out, and in a wet, cold spring. Corn in drills does well on very rich land, but must have room one way to give air. Two-horse plows are always preferable. The necessary farming implements will gradually be made in the Southern States as her prosperity increases. I have used two-horse buzzard for several years, working two mules. I have split middles with two-horse Dixon plows which would have required three furrows with turn plows. You cannot plant corn too deep, because corn grows up but cotton grows down. If yon throw a bed to com every time you plow, you are more than likely to leave a small ditch in the centre of the row. Then, on thirsty lands, unless you get rain plentifully, the water will seek its level and soak to the centre of each row, leaving the bed dry. The manure will not do balf the good, and the corn will fire. If the erop should, from disadvantageous cireumstanees, get weedy or grassy, then turn plows are necessary. If the planter can go over his crop every fifteen days, they will not be needed.

It is economy tor a planter to keep his mules and horses fat. In all the Sonthern States mules are better than horses on account of the intense heat, and because they can be kept, after the crop is laid by, on crow foot and joint grass pastures, while horses require corn. Horses are more subject to disease and require more care and attention than mules. Planting is most desirable business when pursued under advantageous cireumstances; but good implements, good stock, good seed, are as necessary as judgment and diseretion in guiding and plowing. Small farms usually pay better than large. With heavy taxes, unreliable freedmen, and many other discouraging surroundings, a man must of necessity attend personally to every arrangement. In times of slavery the master had but to order to be obeyed. Now he must watch to see that his instructions are carried out. A man must rise early and stay late, control, enconrage, reprimand-in short, the Farm is no longer the play-ground of the retired business man or elegant Southron, but an every-day labor-a work that will weary both busy hand and brain. 


\section{A SUCUESSFUL WAY TO MAKE CORN}

\section{ON ANY KIND OF LAND, P.ARTCULARI STHF LANI).}

Throw up deep and high beds, and let the water formow be deep. Just

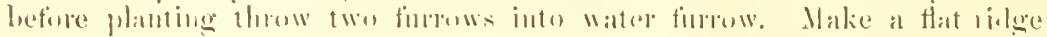

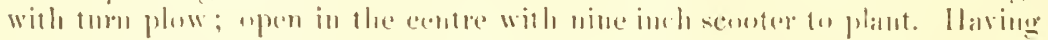

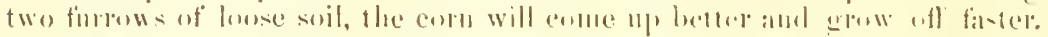

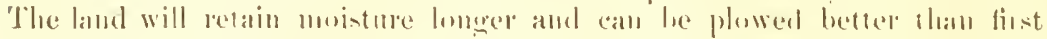

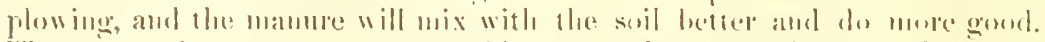

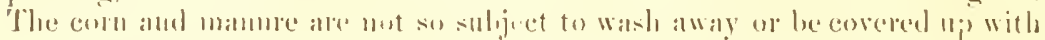

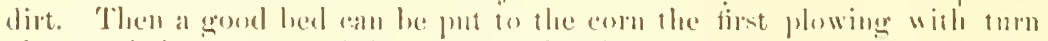

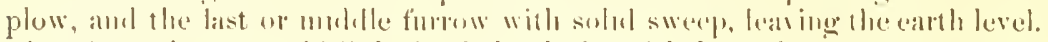
't he after culture on old light land should be with bixon's sweep.

\section{CULTIVATION OF SHORT STAPLE COTTON.}

Lay off the rows thre and a half or four feet wide, with nine inch seonters, tolerably deep, arly in spring, and ron around two gond furrows, forming a

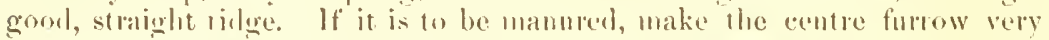
deep. If the manme is not well rotted, ron a second finrow in the first, with two-horse, long-pointed, cleven or twelve inch showel plow. Strew the manure in a wet time, as it will not do well to pot it in diy. Cosere with

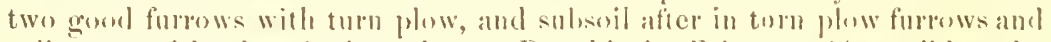
split ont witl shorel plow derep. Do this in February, if possilule-the somer the better, in meler to give the manne sufficient time to mix with the soril, and the latter time to settle.

Mammerl cotton shomlal he dibhled. Make small lubes twenty or twentyforr inches apart, puttiug five or six seed in a hill, and enrer very lighty. Do not make them deep enomgh to distmb the mame. Ihe more enmpact the eutton beds are the soomer the seed will germinate, the more firmly rooted it will be before striking the manme, am the less apt, therefore, to die. Very few planters put mamme in derpenongh. When put in too shatlow the erop receives more injury than benefit. It is chopperl ont at the first or secmel lueing, especially if the conton is allowed to become rery grassy and the plant tums yelow and sheds its fruit. The planter will make at fine crop of grass and weeds, and very litte cotton. The roots greswing mear the surface are haked hy lhe smo, hecome diseased, and many of the stallis die. The talp rout, which mainly supp itts the plant, grows from ten to twelve inclses deep, and muless the mamme is put in very lecp will grow below it.

Colton should be thimmel very early, so that it may grow off rapilily. If it remains ton long it will tall down, the stalks being longe and tember, and

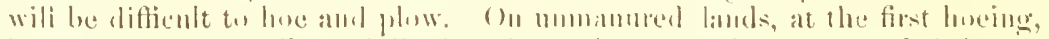

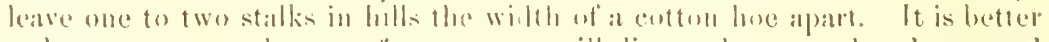
to hate too many than two ferl, as some will die but, he eovered ny hy seend plowing, or be killed by liee, ent rimms, fe. It is impossible to make a full crop unless a good stand is procured. 
On first quality lands, that is. on river bottoms. prairies and islands, good distanee shomld he given. On the hest lands in the Western eutton growing States, planters give firm five to six feet li-lance in the rows by two feet in the drill, loaving one or two stalks in al hill. I knew of one plantation on IIoney lstand, on the ('hulat river, in Mississippi. where the enton was panted six feet by three. The place was owned liy Ridhad T. Arehy, and was the finest cuton lamel I erer saw. In Sieptemlier. 1847, cottun planted as above stated was so thick as to render it impassalide for a lionse letween lle rows. Mr. A. and many other planter's in Mississippi dibliled their enton. putting form or fire seed in a hill. There are many advantages connected wibl this methed of planting. Less seed are requined, a consideration, however, haviug less influenee will the planters in that State, as rery few of them uso the seerl as manure. The principal advantage ganed is the allomit of hacing saverl.

Bofore dithling llie berls are generally scraped off with a heary oak

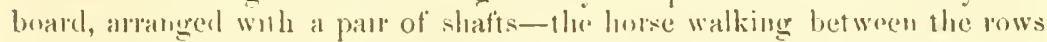
and scraping two hesk at a lime. This leaves them smouth, firm, and in fine orler fur the dibble and for enltivation.

In locing cotton the tirst time, all grass should be carefully elopped and pulled out, as it will be very apt tu be tronblesome if left. especially if June should be a wet mouth. Careless hoe hamb are very apt to cover up the grass around the stalks, and by the seend hoeing it will have taken such firm root that in getting rid of it the stand of enton will very probalily be injured. At the first hoeing the stalks should be well haced with dirt, e-pecially in light, porous lands, as it may be blown down by severe winds, or be covered ip liy caredres plow lands.

At the second hireing kill all grass; leave one or two of the most promising stalks in each hill; and when there is a bad stamd, leave two or three on each side of the missing hills.

At the third hocing, if the plow hands have done their duty, it will bo neessary morely to go over the erop and chop up the bumehes of grass, knocking the dirt from the o ots with the back of the hoe. At each working particular attention should be paid wo charing the glass aud weeds

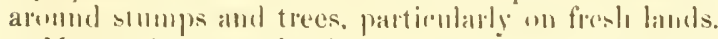

Mammel eotton shmulal receive two workims as early as possible, as it will

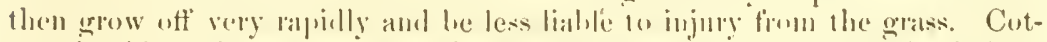

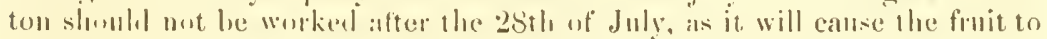

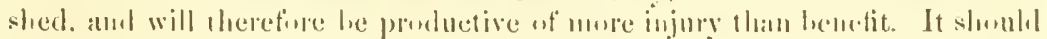

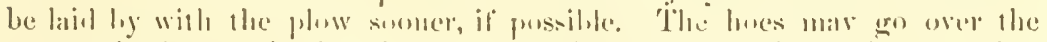

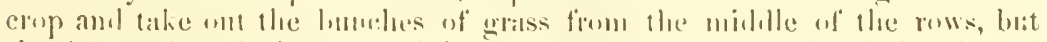

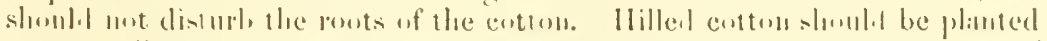

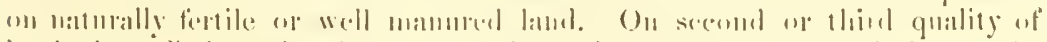

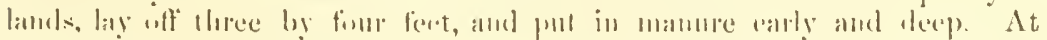

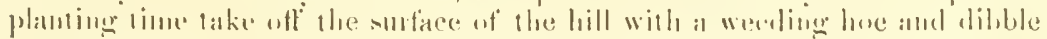

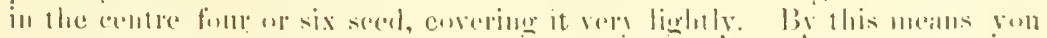

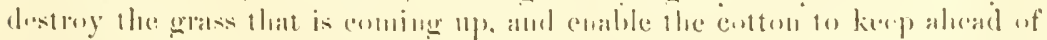

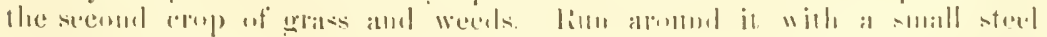

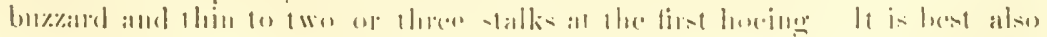

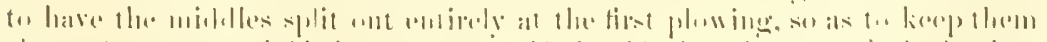

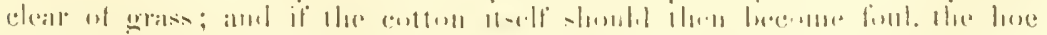

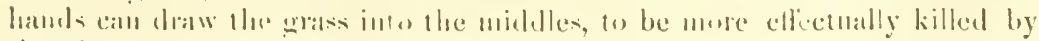
the pluws at the next werling. 
In manuring billed cotton, chop deep holes in every check with grubbing hoe and put in the manure early in the spring. This method of planting cotton possesses many advantages, and will, in my judgment, prodnce a larger yield than the ordinary plan of drilling. Less manure is required, less labor in spreading it, and less seed in planting the crop-an important item in the older States, where the seed are needed as a fertilizer for corn. Hilled cotton also requires less labor in hoeing the erop.

When new grounds are planted in cotton, the seed sbould be put in very early, as they will require a longer time to geminate than on old lands. The land should be broken up early in January both ways, with small scooters, and then bedded. At planting time run a deep furrow in the centre of the bed and strew the seed very thick in order to procure a good stand. Cover with oak board, and afterwards let the hoe tuands go over the field and cover all seed left ont by the buard. If the planter hasn't time to carry out the directions above in regard to new gromels, he can lay off with nine inch scooter, run a second time in the same furrow, strew in the seed, and cover with two seooter furrows. This will give the seed a deep, firm bed, and the mildles can afterwards be split ont with scooters. If new grounds are bedled late in the spring they will be left too porous to retain sufficient moisture for the yome plants, and a bad stanl will be the result.

It is best to plant the land in corn and peas the first year after clearing, as it will pay better than cotton. Cotton lauds should never be rebedred, as this process leaves the ridges too lonse, and the seerl, from a lack of moisture and warmth, whll be less apt to gemninate and grow off rapidly. If the land has been planted in cotton the preceding year, run a deep furrow, with nine inch scooter, in the middles, following with two fnrrows with turn plow. Leave the balks until five or six days before planting; then split them ont with large, twu-borse steel huzzards, unless on rooty and grassy lands, in which case two furrows with a turn plow will be required. If the buzzards can be used they will do very pretty work; leave the beds sufficiently high and will save considerable lator in the preparation for planting. If the turn plow is used, inn only deep enough to plow up the grass and weeds. When realy to plant, rum a three inch sconter in the centre of the bed, and sow the seed carefully and regularly. Nothing is gained by careless or lumried planting.

Never plant when the ground is very wet, as the seed are apt to be corered too deep, and on stiff lands a crust will be formed, which will retard the seed in coming np. After breaking thromgh the ernst the plants will look yellow and sickly, and a great many of them will die.

Cotton shonld not be sown too thick on oll land, as it will he diffieult to hoe and plow, especially the latter part of the crop, which will grow with long, tender shanks befure being thuned. A convenient board for covering cotion may be made by taking a piece of oak twenty-two inches long, sawing an inch deep in the centre of the lower edge, and sloping it oft to a distance of three inches on each side of the incision. This will draw in the dirt on either side, and eover a three inch scouter finrow very nicely. The stocks nsed in covering slonld be very light, so that the seed may not be covered too deep. It will be best to have a special stock male for this purpose.

When cotton is ready for plowing, especially on rongh, grassy lands, it is best to run at twelve inch shovel iu the centre of the middles, plowing as near as possible to stumps and trees; then bar the cotton with a turn plow, 
running only deep enough to corer the grass, and leaving a narrow ridice for the hoes to chop through. This will leave the land in nice order. will prevent the grass from taking loot in the middles, and will enable the planter to dispense with splitting the middles at the second plowing. At that plowing, which should be done as soon as the hoes have gone over the crop, it will be necessary merely to run around the cotton with twenty-two inch buzzards or Dixon sweep. At third working split ont with three or fom furrows with same plows, and at fourth working run only three times in the middles, taking care not to get too near the cotton. At each plowing atter the first, steel buzzards should be nsed, and should be run only deep enomgli to destroy the grass and weeds. It is not advisable to plant low, sandy, hammock lands in cotton, as they will be very difficult to cultivate in wat seasons on account of the grass, and will pay hetter in corn or small grain.

Cotton on rich lauds should be topped about the middle of August, as it will canse the weed to spread and fruit hutter, and w 11 make the bolls near the top of the stalk mature more rapidly and produce whiter staple. This process will be necessary, more particularly when a dronght oecurs and a second growth of the plant succeeds it.

There has been quite a variety of species of the staple planted in this State, (Georgia;) among them the Boyd's Prolific, Texian Bur, Mastodon, Pettigulf, Old Green Seed, Mexican, Dickson, and Zipporah or Silk Cotton. Many of the planters of the Southwestern cotton-growing States have made quite a lucrative business of shipping the seed of the foreguing and other varieties to the more Eastern States, sending them as far up as Edgecomb county, North Carolina. This trade was carried on mostly from Ilexico, Texas, Louisiana and Mississippi, the seed in those States not being needed as manure. The staple in the Eastern States has by this means been very much improved, the seed of the varieties shipped being much smaller and yielding more lint, besides being much more easily picker. The last feature, however, is considered a disadvantage by some, as, mless pieked very soon after opening, it will fall out, become stained, and thus injure the sale of the cotton. If it remains long on the ground, it is best to leave it to be plowed in as manure.

Seed may be improved by a change from red, stiff land to a more sandy soil, or the contrary. This I have proven in my own experience. Planters generally use too little carc in the selection of seed. All cotton from which seed is to be taken for planting should be sunned, and should be sufficiently ventilated, after being put away in the gin house, as to prevent its under. going a sweating process. An excellent seaffold for smming cotton may be made of peeled poles raised four or five feet from the ground by forks. This will give ventilation from beneath, and if the cotton is stirred occasionally the sand and dust will sift throngh the spaces between the poles, and leave the cotton in much better condition for the gin. After the seed for planting are selected, they should not be kept in too large a bulk, but in smaller heaps, so that they may be sufficiently aired to preventinjury from sweating. They should also he occasionally stirred for the same purpose.

Seed should be selected from the second picking about the 10th of October. If the precantions above mentioned were more generally attended to by planters, there would be less complaint of bad stands among them. More attention is paid to this subject in the southwestern States than is given it here. Planters in those States frequently go over their crops, marking the most prolific and healthy stalks, and then have the cotton from those 
wtalk- picked separately, sunned betore being ginned, and the seed kept separate. This plan might be generally adopted and the seed therety much improved. Particular care should be taken that seed are not selected finm cotton that has been injured ly rust, the raterpillar or boll-worm, or where many of the stalks have fied liefore frost. If the caterpillar or loll-worms has injured the cotton. the land should be planted in some other crop the succeriting rear.

When cotton is smunel before giming, less lint will be left in the seed, aud it can be crimed more rapid! and with more ease. If it is damp the saws are apt to berome napped or the gin choked, eausing considerable lows of time. besides cleaning the seel very imperfectly.

The old Green Sced Cotton mentioned above was planted as long aro as I san remember--ahout 1828 -in small patches. These were soon enlarged into fields: and the sect of other rarieties imported from the West, anong which wre the Mexican, Ma-tolon and Pettigulf. Other species still, as the Boyd's Prolific, Zipporah and I'ickson's Prolific, have been developed more recently. The last named variety is considered ly many intelligent and successul planters as the best known. I cannot speak from my own experience in regard to it, as it is the only kind of those alore mentioned that I have never planted.

The Boyd's Prolific bears incly, and open nearly all of its fruit before

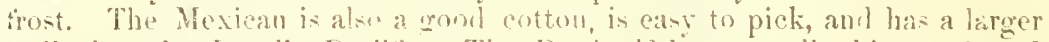
-talk than the Borel's Prolitir. The Pettignlt lias a small white seed, and Jwe not lifler muli from the Sexion. The Zipporah bears a finer staple, but is not " prolific as the wher varietics. The Mastodon grows very tall, bears but few bolls, but rely large ones, and grows until frost. Its culture has been superseded by better kinds. Tho Texian Bur is werely an improved species of Pettigulf.

Oak and hickory latds, with red clay tummlation, are hest for cotton, holding moisture and huanure better than lighter soils, and for that reason aluo more susceptible of inprovement. Some pine lands make a fin weed, but do not boll as well as the oak lawis. Fray lands cause cotton to grow off earlier and more rapidly than red lands, hut do not bear frnit as long. Lands that heame boggy in the spring would nerer be planted in cotton. as they will he rery diftienlt to enltivate. Tands lying on ereeks or brancher will do best in exiton, as it will suffel no iujury from coons and squirrels. The cul. livation of cotton will mow pay larer interest on the funds invested than any uther cop in the sumborn States, wen though the productiveness of lato: under the prewent sytem has been diminished at least fifty per cent. Planters astally derret tou large a proportion of their crops to cotton. It will pay better to plant less mil mamure more lighly-to devoto more land to eorn and small grain, raise inore provision and more manure at home. I have been planting cottum for forty years in six States, and I know from experiener that it is a difficult crup to manace, esperially where it is planterl largely in grassy lands. There is very little pleasure in cultivating a grassy erop of cotton.

Iands lying near large open ponds or lakes generally prodnce cutton well. The ponds should never be drained, as they camot be eultivated to any ad. vantage, and they are murr apt to cronte malaria and canse sickness. When filled, the grass and water werds around thelis afford fine pasturage for stock. The expense of keeping open the drains is very heavy, and crops on these landk are very apt to suffer if the seasmo shonld be at all dry. I har several 
open ponds on my plantation in Burke county, and expended eonsilerable capital in kecping them lrained, but found that it was a very mprotitable investment. Ily fanily also suffered more fiom the effeet of miama than before the drains were cut.

Large amounts have been expended by planters in the sunth for the pur. pose of rendering these lands arable, but usuall, , I think, with very inadequate results. I would, therefore, alvise that these ponda be left undisturbed by the spade or plow.

There are some boggy lands in this State sometimes temed by planters cow-hide lands, becanse they have 110 clay foundation. Thene and the pipe elay soils generally pay a very small per centage of profit for the expense of cultivation, and I would advise those wishing to purchase land to aroid investing in either of the kinds above named. To these may also be alded lands infested with either nnt or joint grass. It is very difticult to cultivate a crop in such soils, and almost impossible to get riil of either species of grass. The latter atfords fine pasturage for stock, but should not be allowed to spread over fields intenled for cnltivation.

Groken lands, if planted in entton, slonld be eultivatod horizontally to prevent washing. It is best, however, to sow them in small grains, as the labor of cultivation is much more severe on man and beakt than when the lands are level.

I bave planted cotton in every species of soil in the Sunthern states; have made farming my occupation and study since 1828 ; and give the foregoing as the result of my ubservation and experience in the culture of the staple during that period.

The above chapter was written in the year 1868 . In the years 1869 and 1870 I planted the Dixon improved seed. It proved to be a very prolific, close bolling cotton, very early, good staple, and easy to pick. In planting, it should be left thick in the drill; two stalks the widtl of a common cotton hoe apart, and not orer three and a half feet in the row, unles the land be rich. It is well suited to any latitnde in the Cotton states, and has the advantage over any other in the northern portions of these States, where the seasous are short, since it eomes very early and matmes nooner than any other species I ever planted. To inprove the growth, vield and staple of cotton, select about the 10tly of October from a fertile field that has been well cultivated. No cutton should he picked from that ficld until the select eotton bas been gathered. Solect the largest, healthiest, most prolific stalks, and from the most prolific limbin, that have from six to twelve bolls on them, and from the centre of each stalk pick two or three bolls next the stalk. These are large and well matured bolls, and having opened early, will be likely to produce early cotton. Select bolls that have five locks of cotton. After the cotton has been ginned, pick ont the black and green seed, and retain the white seed only. Plant small patches of from fire to ten acres of the best land, well fertilized; from these select your seed. Cottou cau thus be greatly iuproved, and it will pay all planters thus to select their seed every year. The Mississippi planter thus select their seed. A large planter who was very successtul pursued this plan. Every year he planted a brag patch, the cotton from which he called donble extra. After a few choice Lolls were selected for next year's patch, the patch was picked clean to plant the large fields. The seed was minch improved, aud better than seed taken from fields where no selections had been made. Most large planters planted 
with a libble, to save hoeing, by distributing the seet more accurately, and all the seerl thas saved was hipperl to the Eastern States; few planters ever thonght of applying the cotton seed ar manure. This little tool-the dithle-consists of only three pieces one inch square each. The rnde diagratu which aceompanies will explain its form and offiees:

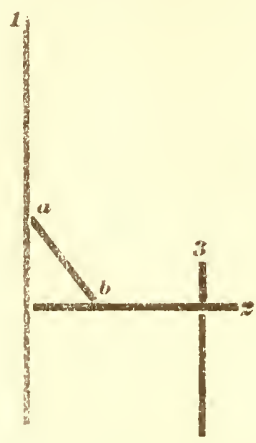

Vo. 1, or the perpendicular strip, forms the handle, and is beld by the wheratur. 'The lower extrenity of this and of $\mathrm{No} .3$ is round pointed so its to make the holes a sufficient depth, which is about one inch. No. 2 has a sot or mortice made through it a considerable part of its leugth, so as No. $\therefore$ can slide back and forth in it and be adjusted to the distance desired by the planter. A brace laid from $a$ to $b$ would give increased strength to the tocl. A laborer posiessed of some vare and judgment is required to place the prints of the libble accurately upon the centre of the cotton bed. In eacli sucuesive application, the point of $N$ o. 1 mast be inserter into the hole previnusly made by No, 2. T'lus extrene accuracy of distance may be intained in planting the seel. Four or tive seed are snfticient, if sound. Where cotton is dibhled, it is best to cover the seed with a hand-board. This is a rely light and convenient tool for the purpose, and is mate of a small piece of irvol, inch board, four inches wide and six long, attached to a handle like a weeding hoe's. It requires somewhat more time and labor to plant a crop in this manner, but in the result it will prove remunerative.

Cotton seed, for planting, should never be soaked, unless the land is in a moin condition. If the land be very dry, the seed will spront; and for want of smroumding moisture, the sprout will perish, and a bad stand will be the consequence. On light, sandy lands, for short staple cotton, secure a small bed to plant on, and cultivate entirely with the Dixon sweep. This is the bust uode of enlture, especially if the land is fertilized.

\section{I)W' LAW'S COTTON PLANTER}

Is the hest now in common use. It sows the cotton seed or guano very regularly, in amount as you may desire, thick or thin; easy to manage, and not apt to get out of order. 


\section{CULTIVATION OF SEA ISLAND COT'TON,}

\section{LONG STAPLE-BLACK SEED.}

This cotton was planted extensively, previons to the war, on the sea coasts of Georgia, Sonth Carolina and Florida, growing well on the plantations on the main land bordering the shore, but hetter on the islands adjacent. In the years 1844 and 1845, I planted some fine seed, called the Big Cream, imported by Mr. Seabrook, of Sonth Carolina, on Skiddiway Island, producing very fine staple, but a short yield. The same years I planted another kind called X Y, not so tine, but more prolific and harder. Two bales to the hand is the average crop. The lands are light, spongy and porons, requiring very little plowing, and fertilized with marsh mud and sea weed.

I propose, from my own experience, giving a few plain practical hints on the culture of the same.

Ridge up the land early in the autumn. Lay off the rows as nearly straight as possible, making them four feet wide. This is done with a weeding hoe. Collect all the weeds and litter and spread in the centre of the low. Sometime abont the 1st of January, cover the weeds with marsh mud, this being a preferable fertilizer to sea weed, as it takes the latter too long to decay. Then with the hoe form a bed sufficiently high to plant your cotton, and let it stand till planting time. Just before planting side haul the beds and draw off the weeds like drawing off sweet potatoes for planting. Weed the top of the beds and put in your seed abont the 1st of April. Drill small holes about twenty inches apart, and plant from four to five seed in a place. When large enough for the first hoeing, side hanl on both sides and thin to three or four stalks, never thinning to a stand till second boeing. At that time, two stalks in a place will be snfficient.

The land is generally saudy, and cannot be made too rieh or compact. Great care is also necessary, owing to the manner of fertilizing, to keep down the weeds and grass. The rich land not only produces more cotton, but a finer staple, and gins to better advantage.

For many years the planters ginned their cotton with roller gins by hand, but the improved horse power gin has rendered the bnrden lighter and a more profitable yield. On the chain of islands stretching from South Carolina sonthward to the Gulf there is still every indncement to planters. Flint corn, sweet potatoes and long staple cotton are the principal crops. No fencing is required by law; saving the time, labor and money requisite for the same, and leaving ample opportunity to mellow and fertilize the ground. Fish and oysters are taken in abundance, requiring little or no meat; consequently very few hogs are ever raised on the islands. The little plowing needful, and all the hauling, can be done with oxen, kept at very little expense. 'The work can be so planned, by judicious management, as to lose no time.

During slavery the hands were tasked, and generally finished in time to tsh, and probably did less work than any laborers in the world. They cultivated from seven to nine acres to the hand, and did it with the hoe. Deep ditching and thorough draining is necessary, in order to shut off the salt water, which, in tides and storms, overflows the islands, and causes the cotton to shed its fruit if it remains on the land any length of time. But all this 
ean be so arranged with water and lam an to avoid heavy outlay and expense.

The clinite is mild and salubrions even in winter, and in summer there is little danger of ferer w those who are not exposed to the sun. The sea breeze is very delightfinl. Brean is easily raised; and with the oysters, clans, fish and turtles, and finest inullet in the world, there is no prospect of starration. (Oanges and lemons ate suecessfully cultivated, and the salt water hathing is one of the ureatest luxuries. Buating is the common method of traveling, owing to the scarcity of horses. The crops are nade with far less work than thuse in the up-eomutry. (S)m is nu object save to bread the community, and the cottun alway so commums the highest prices, giving an iverage of ready money rarely equalled. In 1843 I carried hands from

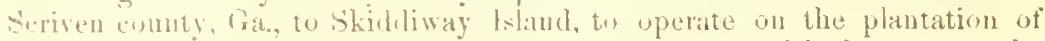
Major Starle. I remainet for two rears. The Hajor wished ne to try the up-eountry methol of cultivation, anil I carricd number one plow hands, but it would not do. I dicl not make lualf a crop. The plow left the land su louse that, with the first sturm, halt the eutton blew up by the roots. My hands laid bern aechstomed to work all day, and regardet the matives as brithing and worthles. Hy men wonld do as mnch work as any two of them; and having no relish for fish or uysters, conlel not be prevailed npon to join any of their excursions.

Atter having manaced business in nearly all the cotton growing States, I believe I can sately ay that. with judicions managenent, there are few places in the world where mere moncy cau be made, with as many comforts, as few disculvantager, as little latbor, and as comfortable a general arrangement, as on the seabuard of South (arolinat, Georgia and Flurida.

Select for lone staple entton as directed for the short staple, reversing the selection by taking out the ween antl white seed, and leaving the black to be planted. The long staple cottun of J. V. Jones, Six Oaks, seleeted in this way, is more prolific, has larger bolls and stalks, and is less liable to rust of any blank seed cutenn I hrave exer planted. It is well aulapted to the piue lands in the vicinity of Augusta as well as the lands of the up-country of Creorgiz. "ine long staple on any kind of land will yield more per acre cnitiviten with the line; and the manure, of whaterer lind used, shond have a liberal allowance of salt mixed with it. It shonld be put in deep, and the cotton eultirared with a Dixun swees, monce in the row, and hoed by latuling wp the eartls in buth siches of the row lightly.

\section{LOW LAND GOLDEN RICE.}

In the cultivation of low lan! fite swamp crolden Rice, the land must be iramed thoromghly. Rice lands should be laid off in plots of ten to thirty aeres in extent. On calch side of these rice fields, next the river and next the high land, two larese lifches, which are called cantils, whould be eut, and in large fields one through the centre, connecterl by ditches less in size "alled ditehes, and these loy still smaller ditehes. Separe drains from the plotis, so that the water may be taken of in due time, and all the crop may he planted, flowed and enltivated at the proper seasuns. The ditches that run inte the canals must be wider and deeper than the drains from the squares, su that the water may run freely into them from the square drains. 
At the mouth of the river-sicle eanal there mut be a good trunk sunk deep in the bank, and made not to leak, and a gond flood gate to take off and to hold water.

Break up the land in Derember with one-horse plows five inches deep, to expose it to the winter frost. Just before planting harrow it level. and roll it, if neeessary, to break the elods. Lay off the rows eighteen inches apart in the drill with a planting plow having a narrow wing on each side to throw ont the soil to the right and left. Lay it off from four to five inches deep. Plant on the first quarter of the moon, in March, if the weather is favorable; if not, on the first quartor of the moon in April. Three bushels of seed will plant one acre. In nrler to get a good stand, cover the rice from two to three inches deep with a hroad weeding hoe. As son as the rice is planted flow it, so as just to cover the rice field witl water. Let the water star on till the rice is spronting and up; then take ofi the water cradually. When all the water is taken off and the field lried, it is to be noticel that bird minders must guard the birds from the rice fields. As soon as the rien grows three inehes high flow it again, and let the water stay on till the rice gets from five to seven inches high: then take off the water gradually again. When the field rlys hoe the rice and take ont the mrass, amitake the clods off the rice. As soon as the field is hoed flow it again just so as to cover the rice, and let the water stay un a week or ten lars. After hosing over the second time fow it again. Let the water stay ou till the rice is nearly ripe; then take off the water, and as soon as the ficlll drys hoe it if necessary; if not, How it, and put on the long flow and let the water stay on it till the rice is ripe. Then take off the water gradually again. At every flow the water must be let nff slowly, and the trash taken off the rice before the water is let off, or it will settle on the rice after the last flow. In a few dily the rice will be ripe; then eut it with reap hooks from twelve to fifteen inches above the surface.

Lay the sheaves smoothly on the stubhles, sn the air ean circulate heneath them. Let the riee lay until it is perfectly cured and olry; thers tie it up into small bundles. It never should be tied up wet. The arerage task to cut is one aere per day. Tie the rice up and put it inte small enck- all orer the field. It can remain in those cocks two and three munths withont damage, if necessary. After all the rice is ent in the firll it can then be taken to the rice tarn, carried in those canals in small that boats up to the barn yard. It may be then stackel up into large ricks, on larce scaffolds made for the purpose. Those rieks are from ten to twolve feet wide at the base, thirty feet long, ten feet high. If the land is very low the baln yard must be seeured by entting a ditch aromnd the barm yall. thowing the dirt out on the opposite side. In case of very high water those ricks must he examined often to see if they dry. If they should heat they mot he taken down aud dried and then stacked up again into small ricks. For seed rice procure the largest, best matured grain. The scerl shomld be perfectly lipe and staeked to itself, and must he beat nut with frailing poles and put away dry. As soon as the riee erop is gathered the ditches and canals must be eleaned out down to the firm, hard bottom, and the loose dirt on the sides taken off and the levees made higher, if necessarr, and all the leaks stopped. They should be cleaned ont twice during the vear; they shonll he notired, and if there are any leaks they should be immerliately stopperl. If there should be any dry spots which cannot be flowed with water, ther should be covered very deep in planting to keep them from the lirds, and cultivated 
entirely with the hoe. Rice planters generally make a solution of coal tar and soot to mix with the rice when planted. 'T'he mixture may be thus made: Take one quart of coal tar to one gallon of hot water; mix it while hot in a trough or tub, and stir it up till it gets to be unilk warm; to that quantity put in two bushels of rough rice, and stir it up till it looks like it had been varnished; then put in soot enough to keep the grains from sticking to each other. It can be sowed more regular. If there should be a cold spell of weather about the time the rice comes up, in March or April, or at any time, the rice must be flowed with water just $x$ as to cover it, and keep it on till the weather turns warm; then take off the water,

Lands best arlapted to growing rice are those swamp and rust lands lying immeliately arljacent to tile-water rivers, between 29 and 33 degrees north latitude. They are generally alluvial, and consists of blue clay and yellow molted clay, or black bay lands. Both contain a large per cent. of isingglass, very important to rice erops. There is another elass of lands adapted to rice as inland swamps. Those are large basins or lakes, surrounded by high lands, having water muning into them, by which they are inundated. These basins being drained are easily reclaimed, and a portion is usually set as a reservoir for holding a sufficiency of water for irrigating purposes. These lands, thongh not so profitatle as the river swamps or ticle water lands, generally, under good management, produce beavier grain, and is recommended by most planters as best for seed. They generally have heavier soils and harder to cultivate.

Tide river plantations are usually loeated a little above the junction of salt and fresh water, and extend up the hanks of the rivers so far as the rise and fall of the tides are sufficient for flooding and draining. This rise and fall should not be less than three or four feet, and six or eight feet is to be preferred, on account of the more perfeet drainage of these latter beights. Bice plantations are located ahove the junction of salt and fresh water from the fact that rice, being an aqnatic plant, requires a vast amount of fresh water during its growth; salt water being fatal to it at all stages. The open trench planting of rice bas been alandoned and soaking in elay given up. It was thought not to pay. Cover the rice with dirt three inches deep; it is the safest way to get a stand. There is uo saving of time to plant in an open trench. If the water at any time becomes stale and the magot $\mathrm{fly}_{\mathrm{y}} \mathrm{a}$ white worm-attacks it, the water must be taken off for one or two days and then replaced with fresh water, and a guage mark set to keep the water at a certain height. Where water is abnndant the magot can generally be avoided by changing the water once a week. To do so skilfully, both gates must be opened. At the young flood the stale water will rnsh ont and fresh water come immediately back with the rising tide, to finat the rice leaves and prevent them sticking to the ground in their fall. If the magot becomes damaging the field must be dried immediately. The presence of the magot may always be suspected by the stiff and unthrifty appearanee of the rice. If there be no grass after the second hoeing, it should not be hoed any more. If eat tails and suckers should appear, they shonld be pulled up and laid on the banks, to expose them to the hot sun. The last flow, called the harvest flow, at the end of fifteen or twenty days, the water is returmerl to the field as deep as the rice and bauks ean hear it. This water, when circumstances permit, is changed every week or two, by letting it off on one tide and taking it back on the next-inereasing the guage with the growth of the rice. When the heads of the rice are in the dongh, near the surface, and 
well filled, it is then fit to cut, and should be gathered as soon as possible, or it will shatter ont. Draw off the water five days before cutting so the land will dry. It is said the first rice that was ever planted in the South was planted in a garden in Charleston, South Carolina.

There are some fine rice lands in the lower part of South Caroliua, on Combahee, Ashley and Cooper rivers, and some fine rice lands also in Genrgia, on the Savannah river, and on the Little and Big Ogechee, near Savannah. Rice planting is a good business, and will pay well if rightly managed. It requires skillful management and close attention to business to suceed well with a rice erop; to know how and at the right time to flow, and to take off the water. The ditches, eanals and trunks must all be in complete order, and kept so. I have known two and three days' neglect to inin a large rice crop. There is no crop that requires more attention to be given than rice. and particularly golden riee, that has to be flowed with water. A man must have energy, industry, and be at his business all the time, or have a man in his place when he is absent, day and night. In slavery time the planters had black drivers to keep the hands at work, and white sub-overscers, and a practical rice planter to come every two or three days to give instructions. It is a very difficult crop to manage, and, if neglected, will fail. I have given ald tirections necessary for preparing the lands, and cultivating and harvesting low land golden tide swamp South Carolina rice.

\section{CULTIVATION OF UPLAND RICE.}

The land should be well prepared by deep plowing, and all stumps and roots being removed. It should be plowed and laid off with a scooter, eighteen inches between rows, and be left very thick in the drill. Plant any time during the month of April, about two inches deep, and cover level with the surface. The white rice is always planted on upland, but on low, pondy lands, any kind will do better than on very dry lands. Low lands are culti. vated altogether with the hoe, but on high lands the plow should be used, and all grass taken out with the hoe. The dirt should be lightly thrown up on both sides. Two bushels should be planted to the acre, and on fine land it will produce from forty to fifty bushels. Watch very closely when coming up, in order to keep the birds from pulling it up. Soot and coal tar is often a preventative, when mixed with the rice.

The low lands produce rice so much better than the uplands, it is generally thought by the farmer cheaper to buy than to cnltivate it. But I think every farmer will find it profitable to plant at least as muclı as he can consume. 


\section{THE CULTIVATION OF SUGAR CANE.}

There are several kinds of Cane, called Ribbon Canc, Green Came and Blue Cane. Sugar Cane is a profitalle crop where the season is long and hot; a slight frost injuring it materially. In Lonisiana it is the principal crop. It $i s$ enltivated to some extent in most of the Critton States, as far North as Edgecomb county, North Carolina. It is extensively cultivated on both sides the Mississippi, as far as the mouth of the Rerl river. The longer the season the better. The land shonlal be very rich. For small patches, cow-pen land is the best. It can be suecesfully raised on ponr land by penning cattle on the land, or fertilizing with cotton seed. This is mneh better than stable manure, making the stalk more juicy and the juice sweeter. The cane is less apt to fire. Nost of the Georgia planters use cotton secd.

The Ribbrin and Blue (Jane are hardest, and keep best during the winter. The Green Cane is softer and yields most juice. The land must be broken deep in the winter scason and the cane planted early, as it takes it a long time to come up. A few days before planting bed it up as you would for cotton, only, if possible, making the beds higher. Have your rows from five to six feet wide; it requires good distance for the air to pass through. Cultivate sugar cane precisely as yon would wide drilled corn; and when it is to be hoed, just draw up the dirt lightly on both sides of the row in the first and second hoeing. The third hoeing, just flat weed and cut out and pull up the grass and weeds. The crop should be plowed often-four times, if possible; with scmoters the first time. Split out deep with turn plow. This will leave the sugre cane deep in the ground. It shonld be planted deep, in a deep water furrow, putting the eotton seed on top. Be sure and have the cotton seed woll rolled, for fear the seed will heat the cane and prevent it from coming up. After the second plowing, plow with Dixon sweep twenty-two inches. After it has been planted long enough to come up, just before, scrape off the top erust; this will kill the first crop of grass and weeds, and the cane will eome up much better and more regularly.

In Louisiana the cane is never planted but once every two ycars; it is cut down level with the ground, leaving the roots to spring up in the ensuing spring. The roots are covered sufficiently to protect them from frost. It wonld be a great deal of trouble to plant cane extensively every year. There they have the rows from six to seven feet wide, and very thick in the drill. When they plant they lay the stalks down in the water furrow and cover with two small scooter finrrows. Just before it is time for the cane to make its appearance on top of the ground, they weed off the top, and this brings on the cane ahead of the grass and weeds. The crop is easy to cultivate but difficult to gather. When the crop is gathered the Louisiana planters have a sugar boiling, in the months of November and December. Then the hands must work by day and night to grind and boil the cane. It is hard, confining and very disagreeable work. Sorve planters employ two sets of hands-one to work by day and one at night. Others have two sets-one to cut the cane, and the other for teamsters.

I visited Col. Minor's sugar mill in 1848. It cost twenty thousand dollars; a very extensive house-sugar and syrup - both manufactured by steam. There was a large house where the mill was stationed, some twenty-five feet 
from the gronnd; a large shed, where the caue was hauled and thrown on revolving cane carriers, to earry up stairs. Then the eane fell into two large boilers, as large as a flour barrel, and about as long. The canc was mashed so tlat that it burned like dry wood. There were gutters that carried off the juice to the boilers, ruming like a small branch. In another shed there were large cisterns to hold molasses and syrup.

I traveled through Louisiana from Donaldsonville to Tibidville, and down as low as Bio Black, and saw the richest sugar lands and the deepest soil I have ever seen. The soil was from three to four feet deep, and as black as tar. I saw some sugar eane so large that a horse mill conld not grind it to any advantage. The low lands in Lonisiana are the best riee lands I have ever seen. Nature has done as much, if not more, for Lonisiana than any State in the Union. It seemed to be laid oft in rows and diteled by nature. The inhabitants, principally French Creoles, have tasteful cottages; and about the middle of October, before the planter's commenee cutting cane, there is no prettier sight in the world than a view from the leck of a river steamer. The snow-flecked cottages, the emerald greenness of the eane, and the white-wasbed negro yuaters looking like little villages, are picturesque beyond description.

The river is in many places higher than the plautations, but the water is dammed back by levees. Like all rich cotton and sugar States, it is not at all healthful in summer, but a most delightful winter residence, and the planters can go down on the salts or to the Balize, or North, or to Viruinia, when the sickly season commences. The country is subject to yellow ferer and eholera, and many epidemics.

During the war a kind of eane called sorghum or Chinese sugar cane wats extensively introduced in the South. It was like any substitute, inferior, but made very palatable syrup. Iron mills were scarce, and wooden mills were used to some extent. It was necessary to clarify it with sorla, and it liad to be boiled as thick as candy, or it would sour. It was a great trouble, and with all this pains-taking considered by many to be very unhealthy. The planters soon abandoned its cultivation, and now there is not enongh of any kind raised for home consumption, exeept along the Mississippi. But I consider it good economy for every man to have a patch large enough to make both sugar and syrup for his own family. In the first place, it is a crop very easily raised; in the second, it is a crop that pays. Any surplus will command ready money. In the third, and no mean consideration, to one who is initiated in the mysteries of sugar boiling, it is cleaner, purer and richer. Last, but not least, it enables the planter to invest his cotton money in more profitable outlay. Every planter should depend on his own resources, raise plenty of meat, plenty of corn, plenty of everything to eat, and then let the prices go up or down-the world wair on as it will-he can ensconce himself under his own vine and fig tree and pop his fingers at the times.

Seed cane should be dug up by the roots after the first light killing frost. Level the ground where you wish to bed the cane. Lay the canes regularly in the rows; lay the roots and then the tops in reverse order alternately, so as to keep the bed level and one uniform height, until about three feet high. If the bed is made too high it will not keep so sound; it will undergo a sweat, and when the seasons are changeable it will be more apt to rot. The heap should be covered shallow, to let the moisture in the sweating process escape-two inches deep of the dry blades and abont three of the soil. Smooth the earth down and leave the top rounding, so that the rain may run 
off. When the weather becomes very cold, cover sufficiently deep to keep the frosts from penetrating to the cane. In warm spells examine the cane; shonld they be found sprouting, take off some of the cover to prevent the mas from heating. In small patches it is best to plant the cane each year, where the land has to be fertilized; and this should be done every year, when the land is poor, for the sugar cane is a very exhansting crop. By planting every year afresh, the land can be better prepared and the manure hetter applied. Unless the soil is very rich, the roots of last year's crop left in the ground for seed will not prodice more than half a crop. In the latitule of burke county cane shonld be planted in the first warm weather it Fubruary. Low, wet, rich lands suit this crop best.

\section{W H E A T}

'The following hints on the cultivation of this grain are from the pen of' Hon. N. S., of Jefterson county, Ga., who is a very suceessful wheat grower, and has prepared them at iny request:

"The tirst thing to be observed, if you expect to be successful in yrowing line wheat, is to procure good seed. Before sowing sieve out all the small grains and soak the seed in a solution of blue stone for twelve hours, allowing one pound of blue stone to five bushels of wheat. If the land to be sown is stubble, turn over with turning plow in August, and by the dark nights in October it will be in good condition to receive the seed. Lay off in 'lands' seven fect wide, and sow a half bushel or three pecks to the acre. If the soil is very strong, one bushel will not be too much. Turn under with turn. ing plow three or four inches deep. If the land has been in corn and peas, it will not be necessary to break it up previous to sowing, as it will have been plowed during the summer. If it is low and wet, the water furrows should he marle very deep, in order to drain the water from the beds in wet seasons. After the wheat is plowed in, run a harrow or brush over the land, so as to leave it as level as possible. Good wheat may be made when sown as late as the dark nights in November. If the land is fertilized, that date will he sufticiently early.

"The foregoing directions are the results of thirty-eight years' experience, an I have been growing wheat for that length of time, and have never, during that period, male a single tailure." 


\section{CULTIVATION OF OATS.}

The land should be prepared the same as for wheat, and Fall Oats shonld be sown about the same time. If not affected by the firosts of winter, the oats will be unch better than when sown in the spring. Black vats are used more for fall than the white oat, because they will stand the cold weather better, and the grains being larger, will weigh more to the bushel. They should be plowed from two and a half to three inches deep, and half a bushel sown to the acre on common lands. On very rich bottoin lands, three pecks should be sown.

The white oats should be plowed in fluring Jannary or February, and as near ponds and swamps as possible. Wet lands suit them much the best, and there is very little profit from sowing them on high and poor lands. After procuring a good seed oat, they should be improved every year by selecting the largest, earliest and best matured stalk. Seed from the Northwestern States prodnce much better in the Sonthern States than those raised here. There is some risk, however, about procuring sound seed.

This is a very valuable crop for stock. Horses will fatten faster, do more service, and be less liable to disease when fed on corn and oats, than when fed on corn alone. The cultivation of small grain has been very much neglected in the South, the attention of the planter having been almost exclusively monopolized by the cotton crop. A ebange in this policy will, I think, be beneficial to Southern agriculture.

\section{CULTIVATION OF RYE.}

This crop is one of great importance to the farmers of the Sonth, and one which has received very little attention. Fields that have long been thrown away will often produce fine erops of rye. High, dry, sandy lands, that are scarcely fit for cultivation, will make fine pastures for stock of all kinds when sown in the proper time. It should be turned under from two to three inches deep, in September or October, for early spring pasture, and in February or March for summer grazing.

The seed of Rye is seldom saved in the South, but when saved should be sown on red lands. From one peck to half a bushel should be sown; the better the land the more needs to be sown. When sown for seed, stock should never be turned on it. In North Carolina eorn is gathered early in September, and rye turned under. As soon as high enough stock is turned upon it; and after being eaten off, it will come out and make a fine pasture for spring. When sown early it takes root, and cannot be affected by the freezes so easily as when sown late. Rye and wheat, after being eut, should always be turned under, as it will improve the land very much. Farmers of the South should all pay more attention to small grain, in order to save coru and raise meat. 


\section{B A R L E Y.}

Sow Barley in the dark nights in February for seed. For winter and spring pastures, sow in the dark nights in August and September. Barley is a very early crop, and will mature on good land in twelve weeks. The four corner kind is very prolific; the double Barley the surest crop. It is thought by a great many planters to pay better for winter and spring pastures than Rye. Plow the grain in three inches deep. Barley is a very disagreeable crop to gather; but planters in the Southern States generally depend upon the Northwestern States for seed. Malt liquors are made from this grain. It is a good substitute for eoffee. It will yield more than Rye to the acre. Both Barley and Rye are so difficult to gather that most planters in the Sonthern States have abandoned their culture, except for winter and spring pastures.

\section{BUCKWHEAT.}

Sow Buckwheat in February, or even as early as Jannary; it will mature in June. Or it can be sown the last of June on wheat land, after the wheat has been ent, and will mature by the 1 st of October. On good land it will prodnce from fifteen to twenty bushels per acre. The Buckwheat flowers are fine for bees. Sow near the bee gums. It may be sown two or three times during the ycar. It will pay well to sow exelusively for the benefit of bees. The whitest and sweetest honey $I$ ever saw or ate was in Rentucky, made chietly from Buckwheat tlowers.

\section{FIELD PEAS.}

This crop, though generally planted with corn, will do best alone. Like most other crops, they require good distance, particularly on good soil. Peas are generally planted too late in the South. Corn should be planted early, and then the peas can be put in sufficiently early without interfering with the cultivation of the corn.

When peas are planted as a separate crop, the rows should be four feet apart, and about a dozen peas should be dropped in hills three feet apart.

The Java and Goat lea are both very early in unaturing. Two crops of the former can be made in a single seasou. It will produce finely upon poor 
land, but is very easily injured br wet scasons, and should be gathered as soon as matured. The Goat Pea will ripen as early as the Java, but the latter is preferable, as it produces a large yield.

The red and yellow Cow Pea remains sound, even when exposed for a long time to cold, wet seasons.

The White Sngar Crowder is a fine table pea, but must have good soil. The Lady Finger and Blue Hull Peas are nice for tahle use. When planted with corn, poas should be dropped between the hills, so that they may be hoed when the corn is hilled up.

The Cow Pea is best to sow for hay. as it produces more vine than the earlier varieties. The Miller l'ea is very prolific and will not decay for several munths when left in the fichl, hut is rery small. The Goose Pea matures rely early, and is nice for the table. The Cow Par is consiclered the liest fir.lil pea

leas slusulil not he planted when the seil is rery dire as the will he very apt w die before coming up. Thiry are very tine for stock, bit are trulle some to gather. It is best to let the streck eat them in the tield, after gathering a sufficient quantity for secol and for ferding to milels cows through the winter. Seed Peas shoulil be picked fom those tirst matmed in good soil. They can, in this way, he very much improwed. When peas are planted with corn, the vines should never be pullerl up, as it injures the land. They should remain in the field to he tursed under with the com stalks to supply vegetable matter to the soil. Planters in the older Southern States shonld keep but few cattle and sheep if they expect to winter them in the corn and cotton fields. They eat the shucks, pea viues, corn and cotton stalks, and the unmatured bolls, all of which should be returned to the soil or it will soon be exhausted. Stock should not be allowed to run in cotton fields, as they will deposit grass-seerls, and thus render the succeeding crop more difficult to cultirate. The stalks should be beaten or chopped down in December, or early in January, so as to be turned under when the land is broken up. The writer pur: ued this plan for a number of years on a plantation in Burke County, Ga., turning under all the corn and cotton stalks, pea vines, etc., and by this means improved land without any other fertilizers. By adding to this the cotton seed, stable manure and the com. mercial fertilizers, the scil may be inproved very rapidly. Where only a few cattle are kept and they are well fed, the manure may not be as much in quantity, but will be much richer than that produced by balf-fed stock. Two n ilch cows, well kept, will yield more milk than a half dozen that are left to pasture on the corn and cotton fields during the winter. Of course these remarks do not apply where stock have the advantages of swamps and cane brakes, or where rye pastures are provided for them. 


\section{GROUND PEAS.}

There are two kinds of Ground Peas, the single and double. The latter is considered the better of the two. Light, sandy lands are best for this erop. The land should be bedded, as for cotton, early in the Spring, the ridges being made about two and a half feet wide. About the first of March, open the bed with a scooter furrow, and drop the peas two in a hill, fifteen inches apart, covering with the foot or a weeding hoe. Ther should be covered very lightly. If moles are troublesome in land intended for ground peas, they should be planted very carly, leaving the shell or hull on them. They will require two or three weeks longer to germinate than when they are shelled before planting. At the first plowing, bar the beds with a very shallow furrow, and soon afterwards, hoe them, drawing the soil slightly to the bills. At second plowing, run a large steel buzzard in the centre of the middles, afterwards hoeing them. Lay them by with same cultivation as directed for second plowing. At the first hoeing they should be thinned to one plant in a hill. Gromnd Peas shonld be planted near the dwelling, so as to prevent, as much as possible, the depredations of crows, as they are generally very annoying. 'l'ley are excellent food for hogs, and will make them fatten very rapidly.

\section{H U F A S.}

A light, mellow soil is most suitable for this erop. The preparation of the land and the cultivation does not differ from that of gromnd peas, exeept as to the number of plants left in the hills. Three or four of the nuts should be planted in each lill, and should, at the first hoeing, be thinned to two stalks.

Birds are generally very tronblesome in a field of Chufas, and, on this account, they, like ground pras, should be planted near the lwelling. The writer planted a crop of ('lutias on his plantation in Burke Comnty, Ga., in 186:, liaving procured the seel fre m Mr. J. V. Jones, of that county. The land planted was very poor, and the comp received but one plowing and loneing, but made a vory tine yiehl. The hirels, howerer, were so destructive that he ahandoned its enltivation, as most oher planters in that section have done for the same reason. The blacle of the Chutia is very similar in appearance to nut-grass, though the nuts are very different. Some plantors have been appreliensive that, like the latter plant, the Chufa would be diff cult to endieate, but their fears were entirely groundless, as the plant will drsappear entirely in two or three years, if the seed are not preserved. The nuts are of a reddish color, and are rather sweet. Hogs are very fond of them. Those intencled for seed should be dried, sacked and hung up. Break upland that has been lying out (broom sedge fields), in November or December; bed up the land the 1st of Mareh, in the latitude of Burke County, Ga; ono furrow in each row, with twenty-two inch Dixcn sweep, and one 
hoeing will be sufficient on good land to make a good crop uf chutas. It will pay to plant them for hogs. No crop will pay better. They are more profitablc, for this purpose, than ground-peas, being more certiun and requiring less labor to cultivate them.

\section{SWEET POTATOES.}

Light, mellow, sandy soils are most suitable for this crop. They suceced best in the extreme Southern States, where killing frosts seldom occur. If the land intender for Potatoes is very poor, it should be well littered with straw or leaves, and should then have cattle penned upon it for some time. After the litter has been well trodden, the land should be broken up with turn plows. The eattle should not be allowed to enrich the soil too bighly, as the vines will grow too luxuriantly. and will not bear so well.

The tirst plowing or breaking up should take place ahout the first of December. About the middle of January the land should be broken again with scooters, and the first of February should be harrowed level. It should then be laid off with scooters in rows four feet apart, on which a bed of two furrows should be formed and allowed to remain until planting time.

The Spanish, Red and Poplar Root Potato shonld be planted the first of March. They should be eut and two or three pieces dropped in hills fifteen inches apart, covering them deep. A short time before the sprouts makc their appearanee, weed oft the tops of the ridges, cutting up all grass and weeds. This will enable them to come out earlier, and will leave them in better plight for plowing. As soon as ther are up, run around them with scooters and split out middles with shovels or small buzzards, running only deep enough to destroy grass and weeds. Then boe them, drawing some dirt to thern. At the second plowing run the bar of the turn plow next the ridge, letting the middles remain until third plowing. Hor them again, and when they need plowing again, run next to them (after a good rain) with the wing of a turn plow, splitting out the middles and leaving a good flat ridge, so as to absorb as much of the rain that falls as possible. At the fourth plowing, split out the middles at three furrows, with large steel buzzards, and "lay by" by hilling them with the hoe.

Yam Potatoes should be bedded about the first of March in the garden, and, under ordinary circumstances, will, when thus bedded, furnish "dirawers" for planting by the last of April. To form the bed, the ground should be leveled and one inch of strong stable manure spread over it. The Potatoes should then be laid on the manure, being arranged so as not to touch each other. Then cover them with two inches of well rotted stable manure, and finish with five inches of soil. The bed should be three feet wide, and proportional in length to the ground intended for planting. It should have an eastern exposure, so as to get the benetit of the morning's sun. The draws will come up much sconer, will be stronger, and have better roots. The bed 
should be smoothed with the back of the hoe to make it form, to enable it to retain moisture, and to prevent the cold from penetrating to the l'otatoes. If there should be verv enld, freezing weather in March, the beds should be protected with pine straw, which should be haid aside as snon as it grows warm again. A short time before the sprouts should make their appearance, abont an inch of soil should be scraped from the top of the berl. If they do not eome ont in five or six dars, rake over the bed half inch deep. If the bed shonld beeme very dry and the manure very hot, water until it becomes thoronghly saturaterl. After the spronts appear, pick out all grass and weeds once a week: nd sift in mellow snil among the plants. When the sprouts are large enough to bo transplanted, open the ridges with a small cooter, and set the "ilsw." fifteen inches apart, and as deep as they were in the bed. Form a bed to them as they are worked, and they will stand a dronght better. If they are manurel in the drill, the sconter forrow will mix the manure in the sil, and thus ronder it more available to the ronts of the plants. If the mamme is not thes mixed, it will remain dry thronghont the season, and of very little henefit to the Potatoes. This will be the ease more particularly whon the manure is not well rotted.

In ledding land fin. l'otatoes, the rows should be laid off with nine inch scooters, followed in the same furrow by a shovel running very deep. The manure should then be put in wet and covered with two nine inch scooter furrows. This shonld toe done abont the first of February, and the beds bould then remain undisturbed until the draws are reary to be set ont, at which time two shallow furrows should be thrown to the ridge with a turn

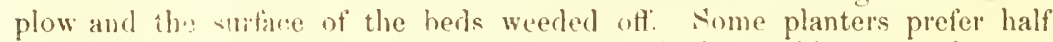
rotted inan'ire for l'otatnes, but I wonld have it thoroughly rotted for any crop. This erop may be made to mature very early by forwarding the "Iraws" in a lot bel." Prepare the bed the first of January, and let the sash remain on it for three weeks; then let it remain open until the first of Febrnar, when the Potatoes shonld be bedded. The draws will then, under favorable circumstances, be ready for transplanting by the tenth or fifteenth "f A A pril. Another drawing may be had two weeks later, and the missing hills in the first planting may lie replanted. After a sufticient number of "draws" have been taken, the Potatoes may be dog up and fed to hogs.

In this, as in every other crop, care must be taken in the preservation of pure seed. As soon as the vines from the first draws set nut have grown two tret, they should be ent off four inclies from the ground, and set in fertile and woll prepared land for raising seed. When ding, the largest should be selected and placed in a reparate hill for this purpose. By pursuing this plan every year the seed may be prevented from degenerating. If small Potatoes raised from draws are nsed for seed, they will soon adulterate. I think they may be improved by being ehanged from one locality to another. or from pine land to oak and hickory, and the reverse. Other crops have been improved in this way, and I see no reason why Potatocs shonld not.

The finest crop of l'otatoes I have ever raised were planted in hills three and a half feet each way. A half gallon of manure was placed in each eheck after breaking well and laying off each way the distance above mentioned. Good, flat hills were then made, and Spanish Potatoes planted deep in each. After the hills became fonl, two or three inches of soil were seraped off, and after the plants were up they were weeded again. Two plowings with a shovel and a hilling with the hoe finished the cultivation. The hilled system was practiced very extensively some years ago, but has been almost aban- 
doned. For small crops, I think it a very good mode of culture. Oak and hickory soils produce Potatoes well, if the lands are fresh and not too low nor too stiff: Pipe clay lands, and those inclined to run together after rains, are not suitable for this crop.

The yield may sometimes be increased by cutting the vines in August or September, when they are growing too luxuriantly. They should not be shortened to less than two feet of the hill. Care should be taken that the roots are not loosened in the operation. When the vines are too long for the plow to pass between the r.ows, they shoml be made firom alternate middles, which should be plowed out and the vines then moved into these from the renaining middles. After these are plowed, the vines should be returned to their original positions, as it is best, in my judgment, for them to remain as they grew naturally.

The Yan Potato is grown more extensively in the South than any other variety. They glow quite large, if well cultivated in groor soil, and hear shipping better than most other kinds. During very wet seasons l'otatoes do not bear well, as most of the nutriment from the earth is taken up by the vine. The vines sometimes take root in the middles and diminish the vield in that way. These may be loosened, and if the erop is not "laid by" a portion of the vine may be taken off and fed to stock.

Potatoes do best when set out very early in the season, as they are less apt to live when transplanted late, and they cannot then thorongly mature. When vines are transplanted for seed, they should be set out in a water furrow late in the afternoon in very wet seasons. No draws or vines should be set out after the middle of June, as the rop will not compensate for the expense of cultivation. Planting too late is a general fault among Southern farmers in regard to nearly all crops cultivated by them. The balks should be split out after transplanting the draws, in order to enable the ridges to retain sufficient moisture. If the soil is sandy and porous, the crop may be cultivated entirely with the buzzard plow. The eulture with plow and hoe should be vely shallow, and at the last working a bed shonld be made with turn plow, finishing the last furrow with buzzard. The vines should not be covered.

The Bunch or Pernvian Potato does well on porr land, and is good for stock. This variety, the Poplat Roct, Spanish, and both species of the Red Potato, do best planted. The White and Yellow Yam thrive better when belded and transplanted. The Buck, at yellow vartety, will do well either way. It grows large, matures early, and is suitable for the table or for stock. This crop is cultivated very extensively in the South, and large quantities are shipped to the Northern States.

The following article has been furnished by Mr. George Th. Cogel, of Richunond connty, Ga.:

\section{ON THE BEST METHOD OF SAVING SWEET POTATOES.}

"They"should be dug immediately after the tirst killing frost. All Potatocs dug in the morning should be picked up in the afteruoon, commencing at two o'clock, and banked. Care should be taken not to bruise them. The cut roots should be kept separate from the sound. The larger potatoes should be separated from the smaller, in the field, by picking up the larger tirst. Potatoes should never be dug when it is very cold or raining. The beds where they are to be laid should be made on high, elevated land. The earth should be dug twenty inches deep, three or four days before the 


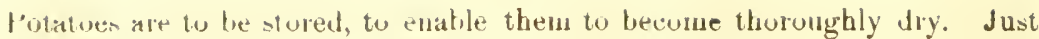
before lepositing the Potatoes, cover the hottom of the beds three inches leep with pine straw. After the Potatoes ure bedded, cover the sides and top of the lieap three inches deep with pine straw; then lay corn stalks three inches deep wer the pine straw, filling in all interstices; then cover tive inches deel, with soil. Be sure to leave a hole at the top to give the lotilloes ail, and to allow the moisture to escape. This is best done by setting up a pole in the centre of the heap, like id fotter stack pole; and when the hill is tinished, is above lirected, llaw out the pole, which will leave a suthicient air hole and vent for the moisture in the sweating process. La! two pules on the top of the hill and on each side of this hole, about three feet long and abont three feet apart. Lay boards acros these so as to make it con ur cap over the top of the Putato hill, and preventing the rain from entering the hole. Laly straw over all.

"Be certain to leave the hole open beneath this cover of boards and straw. The earth thrown up on the sides of the Potato hill shonli be well beaten down by the back of a spade, so that the rain will run off readily instead of soaking in. From twenty to twenty-tive bushels are sufticient for each hill. The Potatues will keep better by this method than they would even in a l'otato house or cellar. I use a small l'ntato louse, into which I put the inferior Potatoes, when I take down a Potato hill, at intervals, to take them to market. They are kept there only a short time, and, when consumed, another hill is opened.

"I have preserved Potatoes by the above method sound until the next erop was made. I have had fifty years experience in the culture of Sweet Potatues, and lave tried various methods of preserving them. I have resided fifteen miles from Augnsta, where the lands are high and dry, and also in Middle tieorgia, where they are very low. But, after all my experience. pronounce the method given above surest, cheapest, and best for the preservation of riweet Potatoes. A smooth surface should be selected on which to lank l'otatoes. I can in no way add to Mr. Godley's chapter on the preparation of the soil and culture of the Potato. I only give my experience in keeping them sonnd after being dug.

"GEORGE TH. COGHL." 


\section{W ATERMELONS.}

Oak and hiekory lands, with clay foundation, are most suitable for this crop. Low, damp soils should be avoided. Land that has lain out is to be preferred, as it will produce finer melons on that account. It should be broken up and harrowed in December, and again broken up deep with turn plows about the first of February. The rows should then be layed off, tifteen feet each way, and holes should be dug ten inches deep in each check. Two shovelsful of stroug stable manure should then be put in each hole and leveled. Then fill in with earth, taking care to mix no yellow sand with it until a hill is formed four inches above the surface. The manure should be put in at least a month before planting, in order to allow the soil to settle and the manure to mix with it. Just before planting time weed off the hills, leaving them about two inches above the surface; make a small ring with the finger around the eentre of each hill, and plant within it five seed. If the plants do not make their appearance within a reasonable length of time, plant the same number of seed just outside of the ring. If these are not up in twelve days, re-plant again inside of the ring.

It is sometimes very difficult to obtain a stand of melons, on account of mice and moles, which are very destructive to most of the crops in the Southern States, and especially to this one. In 1867 I nsed eoal tar and soot on the melon seed before planting, and they were not disturbed by nice or moles, although they had previously annoyed me very much. One of my neighbors, whose first planting had been ruined by these pests, nsed the coal tar and soot and snceeded in getting a fine stand. Some planters have been apprehensive that the tar and soot would destroy the vitality of the seed, but I think without grounds.

It is held by some that the quality of the land has very little to do with the result in the cultivation of melons, provided the hills are well manured, lout I think this a mistake. In order to produce fine melons, the soil should be naturally fertile, and the hills should receive a liberal allowance of manure. The latter should be put in rery deep, as the main tap root of the plant grows to the depth of ten or twelve inches lelow the surface, and the lateral roots branch out very thickly in every direction from it, extencling more than two feet, as I have proven by actual experinent. I raised it very tine crop of melons on the plantation of Mr: E. A. Allen, in Burke County, Ga., by having the holes dug ten or twelve inches deep with a spade and putting a half bushel of manure to each hill. They were of the variety called the "Lawson Green Rind," and weighed from thirty to fiftyseven pounds. I also raised tine crops of this fruit on the plantation of $\mathbf{A}$. J. Lawson, in the same cuunty, having sold a good many in Waynesboro, after furnishing all of the bands on the place with them. The varieties planted were the "Lawson Green Rind " and the "Honey Dew Extra." The former was a species improved by Mr. A. J. Lawson, and took its name from him. It became very popular with the planters in that section, and the seeds were disseminated through several States.

I was very suecessful in cultivating melons on skidaway Island fur the 
Savannah market, for several years; and also on the plantation of C. F. Fieklin, in Crawtord County, Ga.; and of R. T. Archer, in Carroll County, Miss.

During the late war I raised fine melons on my plantation in Burke County, selling quite a uumber in Waynesboro and shipping some to Augusta. Since the war I have been living on a place in Richmond County, thirteen miles from Augusta, and rising fruit and provisions for that market. During the year 1867 , my crop of melons netted me a cousiderable amount of money; but in 1868 the seasons were rather unfavorable, and I planted the rom melons, which is not so saleable as other varieties, and iny crop was not so profitable. I had a small patch planted on the 16th of June and manured with cotton seed, natural soil and ashes mixed, which produced a fine lot of melons, and if they had been the long melon, would bave been a very profitable erop. The round melon is very apt to decay before maturing, and will crack open after ripening.

Cow-penned land is best for melons, with good stable manure in the hills. Manure from cows is too cold for melons, as they require a heating manure to force them to grow off early. It will also canse them to decay before ripening, and will produce more vine than fruit. The manure should be put in sufficiently deep to allow the seed to be planted six or seven inches above it. After the soil settles, it will require but a very short time for the tap root to strike it.

In cultirating melons for market, in the latitude of Angusta, Ga., I would advise only two plantings - the first of Mareb and from the twentieth to the twenty-fifth of May. June patehes seldom do well, being generally injured by wet weather, and by the time they are ready for market, the farmer will have other produce to sell that will pay him at better per cent.

I will now give my method of cultivating melons. As soon as the plants have two or three leaves, loosen the soil lightly around them with the fingers; replant the missing hills and pick out the grass and weels by the roots. Five or six days afterwards plow out the middles deep with turnplows, first running two shallow furrows next the rows and taking eare not to disturb the hills with the plow. Hoe them over on the same day, cleaning off all grass and weeds, and replacing only as much soil as is taken away by the hoe. Level off the soil arumil the hills to the distance of three feet tor the vines to run over until the seeond working. 'The second and third working should he finished as early as possible, plowing very shal low with large steel buzzards and not running too near the hills, particularly at the last plowing. The hoe bands should follow immediately after each plowing, replacing the vines very carefully in their original positions, and taking care that they are not bruised. Melons require considerable care and pains in their eulture, and careless hands should not be allowed in the patch at all. They should not be worked when the soil is rery wet; the drger it is the better, especially on wet, stiff lands that are disposed to bake. Only one variety of seed should be planted in the same field, as they will mix and degenerate.

Seed for planting should be selected from sone of the finest and earliest melons, taking them from the centre of the fruit and drying them on a platfurm suspended so as to be ont of reach of rats and mice. They should be placed in the shade and stirred every day until perfectly dry, when they should be sacked up and marked. Seed thus preserved will mature early, and ean by this method be improved each year. The melons from which 
they are selected shonld be allowed to mature thoronghly before being pulled from the vine, and slonld have a firm, sweet pulp. All melons should be shaded witl bark, or some other material, for fifteen ravs before ripening. They will be sweeter, more healthful and saleable, and will not mature too early. Very wet seasons, or very hot sunshine, will soon ruin them unlese they are thius shaderl.

A convenient and effective method of preventing the depredations of crows upon mclon patehes, is to place stakes around the ficld and encircle it with cotton yam or cord, suspended from the upper ends of the stakes, and heets of tin hung up, in each corner of the patrh, will kcep crows ont. Planters in the Sonthwestern States are very eareful ahont seleeting and preserving seed for planting, much more so than those in the oller States. Seerl from this and all uther crops should be selected frum the first plants or fruit that matures. Julge l'emberton, of Burke County, (ia., pursned this plan in regard to his cotton, and I remember that in 1836 his hands were picking one hundred ponurls per day, during the first week in Angust, when his neighbors' cotton hal seareely begun to open. His corn erop also was, for the same reason, always reiy forward. I have alwass fonnd it to be true of those farmers who were most eareful abont the selection of their seed, that their farms were more productive than when less attention was given to this subject.

Late patehes of melons require less mamnre than those planted earlier. The former shonld have fifteen feet distance between the hills, and the latter from ten to twelve feet, as the vines do not grow so long when planted late. A mixture of cotton seed, ashes and virgin soil make an excellent fertilizer for late melons. A pen shoull be made in Narch and filled three-fonrths full of cotton seed and virgin soil, in proportion of one part of seed to two of soil. Fill up the pen with ashes and beat it down as if it were a coal kiln. Let it stand until two rains have fallen upon it, and then cover with short leat, pine straw as a protection from rain and sun. Melons fertilized with this compost will be very sweet, and will remain sound and good longer than where other manures are used.

Whilst attending to business for A. J. Lawson, of Burke Connty. Ga., I planted two acres of oak and hickory land in melons, using a mixture of well rotted cotton seed, rich earth and strong stahle mannre. Ther were planted in hills twenty feet distant each way, and a half bushel of the mixture was put in each hill and covered deep. The varieties planted were the Lawson Green Rind and the Honey Dew Extra. I never saw finer melons or a more prolific yicld. Some of them were shipped to Charleston and were acknowledged to be the finest in the market.

An excellent manure for melens may he marle hy nsing rieh earth from the woods as a bedling in horse stables. When cleaned ont it should be put $u p$ in pens and ecvered with short-leaf pine straw. as a pretection from the sm and rain. The top of the pile should be eone-shaped so as to shed the rain. The manure should he put up in different pens after each cleaning, and the stables refilled with the same material as before. A good many farmers in Richmond County, Ga., use this manure for melons, and generally supply the Angusta market with very fine fruit. Some of them use a gill of goann to the hill, covering it with a peck of rich earth. Lands in this connty, that have a good clay foundation, produce fine melons, after an application of either of the above manures. The lands lring on the creeks through the conntry produce the finest melons, with a more proli- 
fic yield, and the vines bear for a longer time than on other lands. This erop, like most others, will do best when planted alone. Some farmers plant peas or corn between the rows of melons, but I think it madrisable to mix these crops.

Musk melons and cantelopes should receive the same cultivation as water. melons, exeept as to the distance between the hill and the quantity of manme requisite for each hill. They require less manure and less distance than the latter fruit. No pumpkins or gourds should be allowed to grow near where melons are planterl. Care should be taken that the vines are not trampled upon and injured by any one in passing over the patch. No melons should be broken in the field, and ow a week the ill-shaped and partially decayed melons should be thrown to the hogs, so as to allow those that remain to mature perfectly. Dry snmmers are hest for this crop, as it does not require a very large quantity of rain.

Red or mulatto pine lands prodnce better melons than white sandy sril. They ean be made to mature very early in the season by the following method of planting and enltivating: Dnring the first warn weather in Jannary, prepare the gronnd by ehecking the proper distance, and putting one and a halt peeks of manure to each hill. Prepare a sufficient number of boxes, eighteen inches square, with tops of glass to cover the hills. In the first warm spell in February, eut small trenches around each hill, five inches deep, and fill with cotton seed or eedar brush, the former being preferable. The object of this is to prevent the hills from freezing. 'The seed should then be planted. The boxes should be placel over the hills as soon as the hills are made, lut shonld be taken off at every rain. The boxes and cotton seed should cover a space three feet square. As soon as the plants make their appearance, if it is good weather, the boxes should be removed, and should be replaced only when it is sufficiently cold to injure the plants. An early pateh of this kind should slope towards the East, so as to cateh the morning's sun. The soil shonld be loosened around the plants soon after they come np. On warm days leave off the boxes from $10 \mathrm{~A}$. M. until $3 \mathrm{P}$. M. They should also be taken off whenever it rains, muless it is very cold. If it should tum rery warm after the plants come np, and they should look unhealthy, remove the cotton seed from the trench; and if the soil is rery dry, pour rain water around the hills until they beeome saturated. Then fill the trench with cedar brush or pine straw, and in a few days. if the plants look healthy, remore the brush or straw and fill the trenches with soil. Abont the midlle of March, if tl: e weather shonld be suftieiently warm, take off the boxes, and in four or five days, if the weather is suitable and the soil not too wet, plow and hoe over the patch. If it should turn cold after this, and in all windy weather, the boxes must be used. This method of eultivating early melons is employed by many gardeners in Mississippi, who exhibit eonsiderable rivalry in their endeavors to furnish the markets with the first fruit of the season. It involves considerable trouble and some expense, but if the foregoing directions are followed taithfully, the result will fully repay the farmer or market gardener for his eare and ont. lay of time and means.

In the IVestern and Northern States, where the seasons are three months and a half long, large sized watermelons may be made either in a freestone or limestone comntry, by putting one bushel of freestone sand into each hill. Level it off at bottom and sprinkle one gill of Wileox \& Gibbs Manipulated Guano over the sand. Then put two large shovelsfull of well 
rotted stable manure, cotton seed and virgin soil, well mixerl. Dig the holes thirty inches square and deep. The Cuba is the earliest, the long stripe next. If boxes are procured with glass tops, as above described, Western and Northern planters can raise fine watermelons at home.

\title{
GROWING WATERMELONS.
}

\author{
BY JUDGE SMITII, OF JEFFERSON COUNTY, GEORGIA.
}

"Te be snccessful in growing watermelons the land should be broken deep early in January, and in the 1st of February it should be laid off fifteen feet square; then in each check a hole shonld be dug three feet square and twelve inches deep. In this hole put in from one-half to a bushel of composted manure. Cotton seed and stable manure make the best compost for this purpose; also from the woods put in rich virgin soil, say about one bushel to the hill; mix it well with the compost and make a bill three or four inches above the surface; then plant with good seed from the middle or centre of good melons. Cultivate them fast with a good sweep plow, shallow, not turning or tonching the vines, and you will have goor success in raising fine melons, if the seasons are favorable. If the seaso! is very dry and you want to hurry your melons for market or family use, place in your patch logsheads conveniently, put in the bottom of each about two bushels of corncobs; then fill up abont half of the remaining space with strong stable manure, and the remainder of the hogshead with water. After it stands twelve hours, you can take your watering pots ahont sunset and sprinkle over the vines, or at the roots of them, and they will keep healthy and grow all the time. If yon have any ill shaped melons on your vines, take them off and the balance will grow larger and be better. If grass or weeds shonld come up about the roots, take it ont with your fingers, not tonching or raising the vines, and you will certainly raise fiue melons."

N. S.

In connection with the subject of watermelon culture, I would rema1k that I have found the best soil and culture for watermelons a first year's new ground, prepared as follows: Grub up all the small growth and cut down the large trees as even with the surface as possible; then scooter the land both ways in December; break up in Jannary with steel turn plows, and harrow level; by this means the vines will bear longer, melons will be larger and more prolific; and the land from this careful preparation will be more easily cultivated.

\section{A GOOD FERTILIZER FOR MELONS.}

Make a rail pen in January, with a plank floor at bottom. First put in three horse eart loads of well rotted horse manure. Having leveled it off, scatter evenly over it three bushels of cotton seed and level it off; then put one cart load of rich virgin soil from the woods; then level it off; then three bushels of cotton seed and level it off; three bushels of stable manure and cotton seed; then virgin soil, and so on in rotation, till about seven feet 
high. When thoroughly wet, either by hand or from rains, cover the compost with fine straw, to protect it from the sun and winds.

This fertilizer may be thus nsed: Having laid off the ground ten feet each way, dig at the crossings of the furrows fifteen inches square, twelve inches deep; put one shovelfull of virgin soil from the woods into each hill; level it off; then put one gill of Dixon's Compound; scatter over and put in two shovelsfull of compost; level and make a sharp hill over all, two or three weeks before planting. The manure should he put in wet.

\section{KITCHEN GARDENS.}

The most suitable place is where the land lies fronting the east, so the sun can shine on the garden early in the morning. The land should be as level as possible. It inust not be broken, so the soil and manure can wash away. It is a good plan to pen cattle on the land some eleven months previons to cultivating; breaking up the land and subsoiling it, hauling in leaves and straw three or four times during the year. Turning under the manure and rotten litter mixes it with the soil, and keeps the sun from evaporating the manure. Break up the gronnd finally about the 1st of December; plow deep; subsoil it; harrow it level. Then let it lie till about the 10 th of January; then break it up, subsoil it, and let it lie till February; then lay off the rows and bed them off-the rows about the same distance apart as Cotton, the beds high and water furrows deep. The manure must be put in deep, and planted at least a month before the seeds are sown. This gives it time to mix with the soil and the soil to settle; the gardener can sow his seeds more regularly, and they will come up better.

Some Vegetables require imore fertilizing than others, and this must be put in the drills. For this purpose nse strong, well rotted barn manure, and cover as put down with two scooter furrows; then let it stand two or three weeks before planting. When it is time to put in the seed, weed off the ridge that was made to cover the manure, and weel pretty deep, so as not to have the beds too high. Then secure pure, sonnd seed, and cover shallow. A gardener can make two or three erops on the same ground every year, but for at least nine months he should keep planting, transplanting every week during the spring and summer and fall.

A gaiden should be male on oak and hickory land, with good clay foundations. Light, sandy, porous land may do for spring gardens, but the heat of summer will burn and dry them up. It is a good plan to haul clay on such foundations, but this is not as good as a natural elay foundation. Every garden should have a gate at least ten feet wide, to almit a cart with manure and litter. Vegetables must have plenty of room, as they will grow larger, and the large ones are not only more saleable, but better to eat. Give them plenty of room to be worked, and, if necessary, to be watered. Always water with rain or soft water. Near a city it will pay to bave a garden engine, and a large cistern in the centre of the garden. 
Give all Beet crops two and a half feet width in the rows, and thin out to four inches in the drill, leaving one or two of the most promising plants to grow. When you use them, pull out every other bunch. Mangold Wurtzel Bects are the largest, but raised principally for stock. The Long Blood and Turnip Beet are richer and better for the table.

Carrots should be cultivated in the same manner as Beets.

The Ruta Baga, Flat Dutch and Globe Turnips are best. Give all Turnip crops three feet distance, and thin out to six inches, leaving one or two till they are large enough to eat, and then thin out every other bunch and leaving one in a place, twelve inches apart. Draw up some dirt to them, and you will have fine, large Turnips. They are fine boiled for milch cows.

Radishes should be planted two feet distance, and thinned out to three and four inches apart.

Peppers should have two feet and a half distance, and be thinned to one and two stalks a foot apart.

English Peas should have four feet distance, leaving them very thick in the drill, two and three inches apart, and one or two stalks in a place. Single rows do much the best.

Plant Irish Potatoes the 1st of February, three feet distance and one foot apart. Plant them deep and manure on top. Make the water furrow deep. Jnst before it is time for them to come up, take off the top with weeding hoe. Soon as they are large enough to bear the dirt, plow them with a nine inch scooter. Plow deep and split the middles, and then hoe them. When ready to plow the second time, side with small turn plow and split out with small turn plow. Form a good bed to them, running four times in a row with a turn plow. Then draw up the dirt on both sides of the bed. Get the grass and weeds ont clean by the roots. Make a round bed, pretty flat on top, so as to hold the water when it rains. Do the plowing and hoeing in a wet time, if possible. If pine straw is convenient, cover them two inches deep, and they will need no more working.

Beans should have three feet in the rows and two in the drill, leaving two plants. It is a good plan to plant Beans that climb around the garden fence, as it will save the trouble of frames, and they are but little in the way.

Cantelopes, Cucumbers and Squashes should be planted in hills three feet apart.

Lettuce should have rows two feet apart, and thin out the plants to six inches in the drills.

Onions and Leeks shonld have two feet in the rows and eight inches in the drill. Plant the seed annually in March, and they will mature by the last of August. Manure with guano or stable manure, mixed with wood ashes.

GaRDEN Corn._Plant with rows three feet apart, two feet in the drill, leaving two stalks for use. Radishes can be planted in the midst of the Corn; they will come on before the Corn matures.

Okra should have rows four feet apart and two feet in the drill, leaving two plants in a place. Long green Okra is considered best. Plant the seed the 1st of April.

Plant Tomatoes in a hot house in February, and transplant in March. They are very sensitive to cold. Set them out three feet apart, with frames three feet high. Frames protect them, make them bear better, and the fruit is less liable to decay. Twenty or thirty plants is sufficient for a small family. The large red and yellow are best. Raw or cooked, they are a healthful vegetable. 
Two crops of all root vegetables can be made in a yeal. If the land is rich enough, plant the first crop in March and the other in June.

Most planters sow Turnips too late and too thin. Sow them the middle of June, very thick, and chop them out as you would Cotton. It is a good plan, as so much seed is nearly worthless, to bny Turnip seed in time to test it by sowing a few before the main crop.

Celery requires very rich ground. Set the plants very deep, and put rich carth around them as you work them. Celery requires a great deal of work and manure and water. The finest Celery I have ever seen was raised in Louisiana.

Cabbages and Collards should have three feet distance in the rows and iralf a foot in the drill. As you wish them for cooking, pull out every other one. Sow them in the drill and thin as you would Cotton, and it saves the trouble of transplanting. Early Cabbages should be sown in a hot house.

You can raise Vegetables six weeks earlier in a hot bed than in the open air. A hot house fifteen long and three feet wide is large enough for a good sized garden. Have moveable glass doors, so that they can be opened in warm and rainy weather. Place it in such a position that it will command the first rays of the morning sun. Dig ont about eight inches of natural earth and replace with well rotted horse manure. Then cover with the native earth, and let it stand three or four weeks. Leave the doors open during this time for the soil to mix thoroughly. The cold rains and frost will benefit it. Close the doors four or five days before planting. If you use guano, the pure Peruvian is best. Bone dust at the bottom and horse manure on top is good for root crops. Vines need but little fertilizing, and that put in very deep.

A good kitchen garden is a source of comfort and economy, more depending on the vegetables that garuish the table than the meats. There should, therefore, be such a rotation as to have vegetables always at command. It is much less trouble and care than is usually supposed by the uninitiated, and the pleasure of cultivation oft more than repays both.

\section{H E R B S .}

Herbs should be planted in separate rows, on one side of the garden, and should be transplanted every two years, in order to increase their growth and vigor. There are quite a number of them, most of which are cultivated for their medicinal properties. I have given below the names and uses of thirtyfive different varieties.

Sage, Potmarjoram and Thyme are used as a seasoning for sausages. A tea made of the first is found beneficial in some diseases. Rosemary is also made to serve the same purpose.

A decoction of Rue is given to children as a vernifuge, and is also a good medicine for sheep. 
Lavender and Isaaf make a good tea. Comfrey is sometimes used as a poultice for cuts and bruises, and when boiled in milk is given in attacks of hemorrhage from the lungs.

Plantain coarsely pulverized, with the addition of salt and apple vinegar, is a good remedy for sprains.

Elecampane, when made into tea, or boiled down thick and sweetened with syrup, is used for bad colds.

Horse Radish gives a good flavor to pickles, and when put into whiskey is beneficial for inward diseases.

The seed of Sweet Fennel, bruised and steeped in Jamaica rum, make a good paregoric.

Coriander seed are used to flavor custards and puddings.

Privet and Alum make a good mouth wash.

Chamomile and Hoarhound are fine tonics. The flowers of the former should be steeped in gin. Make a tea of the latter, or a candy by adding syrup.

Feverfew and Wormwood are applied in poultices to swellings.

Southern Wood is good to scatter bone felons.

Penny Royal forms an ingredient in liver and blood puddings, and make a tea for ladies to drink. Boil the root and make a poultice; it will scatter a rising on a lady's breast when every other remedy fails.

Peppermint steeped in cold water is a remedy for nausea, and is beneficial in diseases of the bowels.

Horsenint is used for bathing children. Spearmint has the same properties as Peppermint, but a more pungent taste.

Balm makes a good tea. Catnip tea is excellent for children, and is very nourishing.

Yellow Dock will cure the itch.

Yarrow is used in poultices for boils and risings.

Heal-all makes a good salve for old wounds.

Tansy, double and single, is used as a tea for old persons.

Hops make a good yeast.

Balsam Apple is a remedy for colic, and has a good effect on fresh wounds.

Saffron is used to purify the blood.

Sarsaparilla and Queen's Delight are also employed to cleanse the blood, and have attained quite an extensive reputation for their medicinal properties. Large quantities of the extract have been sold in the South at exorbitant prices, when, by devoting a small portion of the garden to the cultivation of these Herbs, every family might procure an abundant supply, with little or no expense. Both of these herbs or shrubs seem adapted to the pine lands of Pichmond county, Ga., as they grow there wild. The roots should be taken up in September and dried.

The Sarsaparilla grows on hillsides and bottoms-has a red berry and dark leaf-resembles a shrnb known as poison oak, except in the color of the berry.

The Queen's Delight grows on elevated sandy ridges, and has a long leaf. 


\title{
SYRUP OF SARSAPARILLA AND QUEEN'S DELIGHT COMPOUND.
}

\author{
2 ounces of Queeu's Delight root. \\ 8 ounces Sarsaparilla. \\ 4 ounces Guiac Wood. \\ 4 ounces Sassafras Root. \\ $\frac{1}{2}$ ounce Senna leaves. \\ 4 ounces Liquorice Root. \\ $1 \frac{1}{2}$ gallons water. \\ Boil the whole down to 6 pints. Strain and filter. \\ Add $\frac{1}{2}$ pint of alcohol. \\ 1 pint of simple syrup. \\ Dose, tablespoonful three times per day-just before meals.
}

\section{Cultivation of Buncombe Large White Winter Cabbage.}

The almost uniform success which the author has met with in the cultivation of Buncombe Cabbage, and the numerous inquiries made of him by others as to the inethod used, have induced him to devote an eutire chapter to that subject.

The most suitable soil for the growth of this species of cabbage, is tolerably stiff land, with clay foundation, made very rich by being cow-penned. It should be broken up deep in December with a turn plow, followed by a subsoil or scooter plow in the same furrow; after which it should be harrowed nicely in order to pulverize, level and mix the manure with the soil. It should then stand and take the winter freezes until about the tenth of January, when it should be again broken up and harrowed as before; after which it should remain until the first of April. 'Then break up with onehorse plow and harrow; after which reverse the harrow and pass over the ground with the back of the harrow down in order to make the soil as firm and compact as possible.

Breaking up the land in midwinter will enable it to retain moisture better, will destroy insects and worms and will insure a thorough mixing of the manure with the soil, while the winter freezes will mellow the soil and leave it in fine condition for the reception of the plants. If the land should become foul before the plants are ready, it may be flat weeded.

The seed should be procured pure, from New York, Kentucky, or Bun. combe, North Carolina, every year, as they will otherwise become adulterated, and degenerate into the long Collards. They should be sown about the 10th of May, in the latitude of Burke county, Georgia, in a bed prepared for the purpose, in some portion of the garden where they will get the 
benefit of the morning sun. The bed should not be made richer than the soil where the plants are to be set out, as they will be more apt to die, and will not grow off rapidly. A bed three feet wide and thirty feet long will furnish a sufficient number of plants for an acre of ground. A bush arbor four feet high should be made over the bed; then dig up the soil lightly with a hoe; sow the seed tolerably thick and cover lightly. If the soil is made too porous and loose, a good many of the plants will die before transplanting.

If it should be windy or very hot weather for a few days after sowing, the bed should be moistened with rain water, or well water that has been exposed to the atmosphere for forty-eight hours. Discontinue the watering as soon as the seed commence coming up. In a few days pick out the grass and weeds, and loosen the soil between the plants with the fingers, or with a very small garden hoe. As soon as they have attained sufficient size for transplanting, break up the ground with one-horse turn plow; then harrow and reverse as before, or use a roller, if convenient, as it will prevent the land from drying, and enable it to retain moisture longer. Lay off the rows three feet each way, and set out the plants in each cheek. They should be pulled from the bed very earefully, without breaking or bruising, the straightest and most healthy plants seleeted, and should be set out as deep as they were growing in the bed, and as early as possible after being taken up. Care should also be taken to have the soil pushed down equally on all sides in setting out.

After transplanting, small limbs twelve inches long, with leaves on them, should be stuck down on the southwest side of each plant, letting the top lean in a northeasterly direetion over it, so as to shade it during the afternoon. Twigs from the broad leaf black-jack are very suitable for this purpose. Early in the morning and late in the afternoon are the best time for transplanting. If the weather should be very hot or windy for two days after transplanting, the plants should be watered, as before direeted for the bed, pouring about half pint of water around each hill. If they are watered in the afternoon, go over the patch early next morning and cover the soil that has been moistened by the watering with dry dirt, to prevent the sun from scalding the plants or evaporating the water. A single watering will generally be sufficient, unless the weather is very dry; for frequent applications of water will sometimes eause the roots of the Cabbage to rot. If a rain should occur about six days after transplanting, the twigs or brush should be removed late in the afternoon, and earth should be drawn to the hills early next morning. This latter process should be repeated every week, and the ground kept clear of weeds and grass.

If the foregoing direetions are carried ont faithfully the plants will grow off very rapidly. Some of them will probably die, but these may be replaced from the bed, and should be managed as above directed.

About three weeks from the setting ont they should be plowed with a small scooter, running deep three or four times between the rows. It is best to use a very narrow plow, so that it ean be pulled by hand, as it would be impossible to prevent a horse or mule from killing a considerable number of the plants. They should be plowed at least three times, and hoed double that number of times. After each plowing, the soil should be leveled with the hoe and the plants slightly hilled up. Examine earefilly before each hoeing, to see if there are any eut-worms around the roots of the stalks. 
Each hand, when going into the Cabbage patch, should be provided with some vessel in which to secure these worms, which should always be burned. If these pests should beeome very numerous, the patch should be examined every second day. Frequent workings will destroy a great many of them. Land that has been cow-penmed and broken up frequently is not apt to be troubled with cut-worms.

The more thorongh the enltivation the larger, whiter and sweeter will be the Cabbage. The crop requires frequent working, but, if well cultivated, will repay the farmer finely for his lahor. After making allowance for missing hills, over four thousand plants can be raised on a single acre, which, at ten cents per head, would realize over four hmolred dollars. Mr. William I avis, of Burke county, for several years previons to the late war, realized that amount from an acre of ground planted in Buncombe Cabbage. The soil was made very rich, and the seed were procured fresh from North Carolina each year. He shipped them by railroad to Angusta in old erates during the months of November, December and January. The writer made a fine erop of them on his plantation in Burke county, Ga., in 1863, and sold them quite profitably in Waynesboro and Augusta.

Good Buncoube Cabbage cannot be made without considerable pains and trouble in the cultivation. A good many farmers fail in this crop on account of imperfect preparation of the soil, or a want of proper care in transplanting and cultivating. The lower leaves should never be taken from the stalk until the head is entirely formed, as it will cause the Cabbage to head imperfectly. When the head is perfectly formed the stalk may be taken up; the lower leaves that are not well closed up may be removed, and the stalk ent in two a few inches below the head. The root, stalk and leaves may then be fed to stock. The roots should always be removed, as they injure the land if allowed to remain.

The bud worms scmetimes attacks the Cabbage abont the time it is beginning to head. 'They should be pieked off early every morning and burnt, and will annoy the erop for only a few days. The writer once attempted to get rid of them by turning ehickens into his garden, but they soon aequired a relish for the Cabbage, and he had to abandon the experiment.

In the year 1862 the writer sowed Buncombe Cabbage about the 15th of May, and finding that the plants would be too large for transplanting before there was sufficient rain to put the soil in proper condition, he had about four hundred gallons of water drawn, and after allowing it to remain exposed to the atmosphere for three days, had the ground broken up and harrowed, and laid off three fect each way. He then had a pint of water put in each check, and after it had been absorbed, had the same quantity poured in again, and commenced transplanting late in the afternoon, finishing about 1 o'elock next morning. Early next day bushes or twigs were placed over each hill, and in the afternoon they were watered as before. On the morming of the third day dry soil was drawn to the plants to prevent the evaporation of the water, and in the aftemoon they were watered a third time, and the soil drawn up as before. By this means a very good stand was obtained even in a very try season.

In order to make very large Cabbage, they should be planted four feet nach way, on land that has been made very rich and has been well prepared. They can be made to weigh from twenty to thirty pounds each. If the same 
land is planted in Cabbage for several successive years, it should be very highly fertilized each year, as this is a very exhausting crop.

The writer has had considerable experience in the cultivation of this crop, and has enjoyed opportunities of observing the mode of eulture employed by the most successful gardeners in the South and West. He hopes, therefore, that if the foregoing directions are strictly carried out, Southern farmers will have no difficulty in raising Buncombe Cabbage. It is difficult in the South to save the seed of this Cabbage. A fly destroys them when in bloom. When seed are plentiful, in the latitude of North Carolina they may be planted at the requisite distances. But in the latitude of Burke county, Ga., they had better be sown and transplanted, since they have to be shaded until large enough to be set out, and even after, until they take root. They will make larger and sweeter Cabbage, if the land be rich and properly prepared-will grow off and mature sooner when transplanted. Six or eight days befcre transplanting, remove the bushes from shading the plants. This must be done by degrees. By this they become toughened, and will be able to endure the hot sun better-will be more apt to live and grow off more rapidly.

\section{CUBA SMOKING TOBACCO.}

This plant grows finely, and makes a good quality of Tobaceo on the seacoast of South Carolina, Georgia and Florida. In 1845, while farming on Skidaway Island, I procured seed from Major Starke, who had obtained them from Cuba, and I succeeded in raising some very fine Tobacco. The following directions for the cultivation of this crop are taken principally from an article written by a French planter for a New Orleans paper in 1844 :

"Sow the seed in December, in wet, rich soil, and butt the bed down smooth and firm, in order to make the seed adbere to the soil. They will not come up if sown on dry, sandy land. Break up the land well, and lay it off three and a half feet each way. Put a quart of good stable manure in each check, covering it tolerably deep. Let it stand thus for two months; then set out the plants in a wet time, shading them with twigs or brush. Water, if necessary, and replant until a stand is secured. Cultivate with three plowings and four boeings.

"When the plants are about fifteen inches in height they should be suckered once a week; and when the worms make their appearance, they should be picked off every morning and burnt. As soon as the top buds seem to be going to seed, they should be pinched or cut off once a week, or as often as it becomes necessary. A sufficient number of stalks should be allowed to buds for seed, for planting. When the stalks are cut, the seed should be dried and put away for the next year. When the plants ehange to a dark brown color, and the leaves adhere to the hand when touched, it is then ready to be cut down. After being cut, the stalks should be hung up under shelter to be cured. They should not be allowed to touch each other, but 
should be so placed that the air may circulate freely through the whole house. Holes can be made through the butt ends of the stalks, through which strips of wood may be passed, or it may be hung with bear grass as meat is.

"When the stalks have turned nearly black, they should be taken down, and the leaves should be stripped off and covered with blankets or thick tarpaulin cloth, in order to give it a sweat. After remaining in this condition for two months, it should be taken up and the leaves stripped from the stems. Then boil the stems and dampen the Tobaceo with the amber. The flavor may be much improver by the addition of a little clarified sugar to the amber.

"After the dampening, the Tobaceo should remain in a close room for two or three lays, and shonld then be spread out and aired. When it becomes dry, it should be packed up in barrels or bogsheads, and is then ready to be made into Cigars or gronnd into Smoking Tobaceo. The best quality should be used for Cigars, and the inferior grades for Smoking 'Tobacco. The flavor of the former may be improved by being dampened with cologne water."

I made some very fine 'Tobacco on Major Starke's plantation, whicL was mannfactured into Cigars in Savannah and Angusta. I also succeded in raising a good erop of Smoking Tobacco on the plantation of $\mathrm{A}$. J. Lawson, who procured seed from a toliacconist in Savannah, and also on my own place in Burke ennty, Ga, in 1862. Most of the last crop was destroyed by Sherman in his "march to the sea."

Suoking Tobaceo requircs a very warm climate-the warmer the better. I have never eultivated Chewing Tobaceo. The process of curing and manufacturing does not differ much from that of Smoking Tobacco, except that it is twisted and pressed in any shape or size that may be wished. Chewing Tobacco grows best in a cold climate. Either kind may be raised in the Eastern cotton-growing States, bnt not without considerable trouble. The Cuba Tobacco will pay better than the other. Where both kinds are planted they should not be near each other, as they will become adulterated. The seed should be procured from Cula and Virginia every two years. Cuba Tobaceo has very long, smooth leaves, while those of the Chewing Tobaceo are round and inuch thicker. The ash of the former is much whiter than that of the latter; the Havor is better, and it is a superior Tobacco in almost every respect. The Virginia Tobaceo is not suitable for Cigars.

After the stalks have been cut down the roots should be dug up, as they will injure the land if allowed to remain. This should be done immediately, as they sometimes take a second growth.

The culture of Tobacco has never been very extensive in the extreme Southern States, the energies of the planter being generally exclusively monopolized in the cultivation of Cotton.

The hints above have been mostly taken from the article reterred to in the beginning of this chapter, approved by $\mathrm{my}$ own experience in the eultivation of the weed. 


\section{CHEWING TOBACCO.}

A rich loam is the best soil for Tobacco. The spot selected for seed bed should be on the south side of a hill, well proteeted from bleak North winds. The soil should be mellow, warm and rich. The earth should be well pulverized, and where possible, a trash heap should be burut on the spot where you intend to sow your seed. Enrich the bed with Peruvian guano, wood ashes and soot. Sow the seed thickly, and beat down the bed with a maul, to make the seed adhere to the soil and prevent bleak winds from drying it too much. Sow the seed in February, in the Southern States. They may be sown any time during the winter when the weather is warm. Proteet the plants by covering with pine brush or straw. Sow at intervals during the winter, so as to have plenty of plants. The bed must be free from grass and weeds; pick them out by hand. Use liquid manure and soot, after the plants come up, to destroy the black insect. New lands are far the best to make Tobacco. Have the laud in good order where the plants are to be set out. Set out three by four feet. Cultivate as you would Cuba Tobacco or Buncombe Cabbage. When the plants turn yellow, eut them down near the surface by turning up the bottom leaves and striking with a Tobaceo knife. The plants should lie on the ground to wilt; then be taken to the Tobacco bouse and hung up. The Tobaceo house should be well bnilt, airy, and perfectly tight when the doors are shut, so as to exclude the damp air, which will injure the color and damage the quality of the Tobacco. As the leaves cure, put the first hung up closer, to make room for more-as close as possible, without actually touching. When the Tobacco has become dried and well cured, and the weather is mild and damp, it will become soft and pliant. Then strip the leaves from the stalks and tie them up in small bundles. These are formed by wrapping a leaf around the upper end of a handful of leaves for three or four inches, tucking the end into the middle of the bundle.

There should be, if the quality of the crop permits, four sorts of Tobacco: First, second, bright yellow, and dull. It is best not to take down more than can be tied up in a few hours. To bulk Tobacco requires judgment and neatness. Logs should be laid parallel, and sticks or boards laid across these to support the bulk and allow free passage of air from below. Two rows of bundles, put in bulk and carried up together, the heads out and the opposite ends touching, should be built up a sufficient height. Then a few sticks should be laid on the top to keep the Tobacco in place. The heap must ve watched. Should it heat, grow musty, or acquire a bad smell, it must be taken down, bundle by bundle, and made into another bulk, without pressure, that the Tobacco may lie loose and admit free circulation of air. This is called wind-rowing.

After the Tobacco has become thoroughly dry, has the naturel smell in full force, and when a warm and moist spell of weather has made it pliant, it is in fit condition to be made into three, four, or even six round bulks, according to quantity; covered with sticks or boards, and weighted dow with logs, when it will keep in nice order for packing into hogsheads. The best time to pack is in mild, pleasant weather. 'The 'Tobaceo is then packoc 
in any quantity or form that the planter chooses and is ready for market. Tobacco brings a high price, and every planter in the Southern States should raise and cure enough for his own use at least. Both the Cuba and Virginia Tobacco grow well in the Cotton-growing States. One quarter of an acre, well prepared and enriched, will make enongh for one year's use of a large family. Every planter should raise some of every crop needed at home.

The Virginia Tobacco planters, in times of slavery, sent into their fields what they called their trash-gang-children too young for field labor-in charge of an old man or woman. These suckered the Tobacco and picked off the worms. Some planters turned into their fields large flocks of turkeys. These will consume a great many worms, but should not be depended upon wholly. Tobacco must not be neglected. Worms may have to be picked off even after the weed has been eut and hung up. To succeed well in raising Tobacco it requires constant attention. The erop is easy of cultivation and not unhealthy, but the task of curing is disagreeable. It has been said that one who lives in a Tobacco house will never be subject to an attack of cholera. I have now given all necessary directions.

\title{
CULTIVATION OF GRAPES.
}

\author{
BY W. T. KILLINGSWOR'TH.
}

Sandy loans, with clay subsoil fifteen inches or two feet beneath the surface, are best adapted to the cultivation of Grapes. The vines should be set out in holes two feet deep, fifteen inches square, and six feet apart each way. Fertilize with one pint of bone dust to each hill. Press the soil rather loosely around the rine, and leave only one bud exposed. When they are one year old, cut back to three buds on eyes and stake well. Break and subsoil the land two feet deep, if possible-the decper the better, as it will cause the Grapes to grow larger, and the vines will be more prolific. One thorough plowing will be sufficient. When the vines are pruned in January, trim off the roots near the surface. Keep the grass and weeds down with the hoe during the summer. After the blooms drop, the suckers should be removed by hand once a year. The stakes should be six fect high, and the vines should be strongly tied up around them.

When two years old, remove all dead wood; prune as before, reserving a new cane; cut back to three eyes. Cultivate as directed for first year. Continue this process until the vines are four years old, reserving a new eane each year. There will then be four canes, with three eyes to each, which will produce twelve bearing vines to each root. Prune with a sharp knife, as this will cause the vines to hold their leaves and protect the Grapes from the rays of the sun. They will ripen sooner and more uniformly, be less apt to rot, and possess a finer flavor. Do not allow the vines to run too high above the stakes, and replace the latter with new ones when necessary. In the opinion of the writer, no crop will pay better than this when properly attended to. From a trial of a number of varieties, during an experience of thirteen years, he prefers the Catawba Grape for the latitude of Augustr, Gr. 


\title{
PEACH CULTURE.
}

\author{
By W. T. KILLINGSWORTH.
}

A sandy loam, with clay foundation, situated on an elevated hillside, sloping to the Northwest, will be found best suited to the production of this fruit. Lay off the land in rows twenty-five feet distant each way, and drop two seed in each eheck. Cultivate in Cotton or Corn, leaving a space of three feet to each row of the young trees unplanted. Plow this out with sweeps, so as to kill the grass and weeds, without injuring the roots of the trees. When they are one year old, cut off level with the ground and graft with such varieties as are desired. Cultivate the second year as above directed, leaving but one tree to each hill. During the third year eut back to two feet high, leaving about four branehes to each stock, and keep them trimmed so that they may not grow too tall to be reached by hand. If worms make their appearance about the roots, remove them, and apply a small quantity of oak ashes or unslacked lime, after taking away a portion of the surface soil around the tree. This soil should not be replaced, as it will cause the worms to return. While the ground is frozen in winter, apply a load of pine straw to each hill, first examining for worms and destroying them. The straw should be eighteen inches deep, and should extend four feet in all directions from the tree. This will prevent the trees from blouming early, and thus secure the fruit from injury by frosts. After the straw decays, seatter it over the orehard and apply a fresh supply as before. Allow no stoek of any kind in the orehard. If the fruit falls from the trees, it should be earried out in baskets to the hog pasture, which should be situated near the orehard for this purpose. Continue to eultivate as above, and if any of the trees should die, supply their places with grafted seions from the nursery, which should be kept on hand for that purpose.

\section{APPLE CULTURE.}

\section{BY W. T. KILLINGSWORTH.}

Select for an Apple orchard a pieee of level land having a clay foundation. Graft on Crab Apple or Sweetening stocks, or take a limb from a tree of any desired variety and plant in damp, rich, mellow soil, eighteen inches deep, so as to ensure the growth. The last method is preferable, as it is quicker, more eertain, and there is less liability of adulteration. After the scions are secured, set out in rows twenty-five feet apart and eut back to two feet high. Leave about four branches to each, and train them to grow off opposite each other. The 1st of February is the proper time for setting out. 
Break up the land well and cultivate in Cotton or Vegetables. Sow no small grain in the orchard, nor allow it to "lie out." No stock should be suffered to run in it except hogs, and they only in fruit seasons. Prune the trees in January every year, and train low, so that the fruit ean be gathered conveniently by hand. Break the land deeply in the centre of the rows early in January, but plow very shallow for a space of four feet on each side of the trees. In cultivating crops in the orchard, use sweeps near the trees, merely skimming the surface, so as to prevent injury to the roots. The plow should not be allowed to go within three feet of the trees, but the grass and weeds under them shonld be kept down with the boe. Gather the fruit always by hand, and only when fully ripe. Keep the trees clear of worms and caterpillars.

\section{STRA W BERRIES.}

By W. T. KILLINGSWORTH.

This fruit thrives best on fertile bottom lands, with a damp, grey, loamy soil. If the land is wet, it should be drained. It should be broken up, subsoiled and harrowed level. Then lay off rows or trenches three feet apart, and fill these with well rotted stable manure or cotton seed, or with decayed wood. Rich vegetable mould from the woods is also a good fertilizer for Strawberries, and when mixed with decayed grass, heaped up when green, and stable manure, is, in the opinion of the writer, preferable to any other application that he has ever made in twelve years experience. Guanos cannot be recommended for this crop.

The trenches shonld be side-hauled with hoes, making an oval bed. Set out the plants on these beds two feet apart, in October. Divide the roots carefully, and press the soil evenly around them, so that they may grow down into the bed uniformly. They will be more apt to live under such treatment, will grow off better, and bear more and finer fruit. Hoe lightly every three weeks during the spring and summer, or oftener, if necessary, and keep the ridge in an oval form. Remove the runners as fast as they make their appearance, from the time the fruit commences to ripen until the close of the season. This will hasten the maturity and improve the size and quantity of the fruit.

The "Wilson's Improved" is the best variety for the South. The Triomphe de Gand is also a good variety-not so prolific as the first named, but the fruit is larger and of finer flavor. The writer has known thirty-three berries of this variety to measure a quart. Either of the above named, if well cultivated, will, in favorable seasons, commence ripening by the 10 th of April, and on moist lands will bear until the middle of July. On suitable lands four hundred dollars can be realized to the acre. 


\section{PEACH CULTURE.}

BY JOSEPH SAXON.

The most suitable location for a peach orchard is on high, dry, sandy land, naturally fertile and having a clay subsoil. On such lands the trees will grow larger, live longer and bear fruit more regularly than on other soils. The seed should be planted in the nursery immediately after being taken from the fruit. They shonld be sown thickly in drills, about five inches deep, in rich, mellow soil. They will then grow off rapidly, make tall trunks so as to be cultivated with more ease and will bear at an early age. The land selected for the orehard should be broken up deeply, harrowed level and laid off thirty feet each way. At each check dig a large hole and put in a liberal allowance of stable manure and rich earth, well mixed. About the first of February, take the trees from the nursery with as little loss of roots as possible, and as they are taken up, mark the Northern side of each, so that they may be set out exactly as they stood in the nursery. If this precaution is taken, the trees will be less apt to die, and will grow off better. They should be set out, eight or ten inches deep, on the mixture of manure and earth, which should be moist, and the soil taken from the holes, should then be packed firmly around the roots. After setting out the trees, bend them towards the South, so that the trunk will be protected from the sun.

For the first three years cultivate the orchard in cotton, breaking the land very deeply early in Spring, not too deeply near the trees, and cultivating shallow and level, with sweeps afterwards. After the third year plant in early corn and peas, fertilizing the crop so that it may mature by the time the peaches ripen, and it will afford fine pasturage for hogs. No other stock should be allowed to run in the orchard except hogs, and they only while the fruit is ripening. The trees should be trimmed every year to a height of from five or six feet from the ground, so that the limbs may not be injured by horse or mule in plowing under them. Moderately eold weather in Deeember or January is the best time for pruning.

When the trees need fertilizing, take the surface soil from the roots during a warm spell, in November or December, and apply some good compost, leaving the roots partially exposed until March following. The trees will then bloom later and will therefore be less liable to injury from late frosts. The application of a pint of superphosphate of lime, mixed with a teaspoonful of salt to each tree will be found very beneficial in destroying the bugs and worms that infest the orehard.

The fruit should not be removed from the tree until fully ripe, and should always be picked by careful hands. Orehards should not be sown in small grains, nor be allowed to grow up in broom sedge, as the sedge will injure the land, and eannot be burnt off withont killing some of the trees. By planting properly seleeted seed, or procuring trees from reliable Soutbern nurserymen, peach culture can, with good management, be made very profitable. While the latter may be considered the more eertain method 
of obtaining a good orchard, the writer has succeeded in raising excellent fruit from the seed without grafting or budding. From thirty years of successful experience in the cultivation of the peach, he offers the foregoing hints as the results of that experience.

\section{RAISING HAY IN THE SOUTH.}

The South has heretofore been almost entirely dependent on the North and West for hay. The experience of the present year, 1870, should induce every Southern planter to make an effort to raise his own hay. They have been paying nearly all the year two dollars per hundred for this article, which, in a good many instances, was not worth the expense of hauling to the plantation, as no stock that were not half starved would eat it. The crab and crowfoot grasses, which grow so luxuriantly in the South, both make good hay. Very rich land will pay as well in this crop as any other.

The crowfoot grass seed should be sown the first of June, and the ground should be harrowed very level, so that it can be cut nearly even with the surface. On good land it can be cut twice. It shonld be cut in the morning, put into piles or cocks at night and hauled to the barn next day, thirty-six hours being sufficient to cure it nicely. A"large quantity can be made on a small piece of land, if well managed.

Hay can be more cheaply raised than fodder, but planters should make as large a quantity of each as they can, so that all their stock may be supplied. Hay is easily gatbered, int should be cut at the proper time.

\section{HOE CULTURE.}

This method of cultivation, so extensively employed by planters on the sea coast and the islands adjacent, might, I think, be profitably used in all bottom lands throughout the Southern States. The considerations which rendered its use economical on such lands, under the old regime, would recommend it much more strongly under the present one. Then, provisions and stock were cheap-now, they are anything else; and other expenses connected with plow culture, such as gear, blacksmith work, dc., have advanced proportionally. Losses among stock by death and theft are also much heavier than formerly.

At present prices, it would require an ontlay of not less than two thousand dollars to stock a farm for twenty hands, with ten number one mules, their feed, and improved implements, exclusive of provisions for the hands; whereas, under the old system, not more than eight hundred dollars would be nccessary to furnish hands with provisions for eight months, and with the 
requisite tools. Taking into consideration, then, the interest on the funds invested and the risks to be run, the latter would certainly be the safest investment, especially to those who have everything to purchase. Under this system, eight acres of land might be allotted to each hand, after furnishing, them with weeding and grubbing hoes, spades, shovels, mattocks, \&c., and making each responsible, at the close of the year, for the implements furnished. Six acres of the eight might be planted in Cotton, and the remaining two in Corn, which would furnish bread to the bands for the ensuingr year. The laborers might feed themselves, and give the landholder balf the products of their labor.

All the hauling necessary about the farm could be accomplished with oxen at little expense, which might be shared by both parties. A plow might be used for laying off the rows for planting or bedding, in order to have them straight, but this would be necessary only one year, as they could afterwards be kept straight by listing on the middles with the hoe each succeeding year. If this system of culture is adopted, only one-half of the open land should be cultivated, the remainder being allowed to rest, to be put in cultivation the succeeding year. By alternating thus, the fertility of the soil could be kept up. After the crop is laid by, the hands should be employer in reversing the beds on the land lying out, in order to bury the green weeds for manure.

A short time before planting, these beds should be side-hauled and weeded off, to destroy the first crop of grass. If the land is to be planted in Cottorr. small holes should be made at such distance as the plants are to stand-five or six seed dropped in each hill and covered one inch deep. At the first hoeing side-hanl lightly on both sides, leaving two or three stalks to the hill. At the second working thin to one or two plants, hoeing only deep enough to destroy the grass and weeds. Care should be taken that the beds are not left too high.

All wet lands should be thoroughly drained betore being cultivated. Large open ponds and the land immediately alound them should never bc drained, but should be left as pasturage for stock. There are many advantages connected with the system of hoe culture, and under some circumstances it will be found to be attended with more profit than the ordinary method of cultivation. The planter has better opportunity for raising or collecting manure, can apply it to the land more advantageously, and can prepare his soil better for a succeeding crop.

I superintended three plantations in Chatham county, in this State, the same year-one of them using plows, and the others only hoes, in the cult vation of the crops. The latter were managed with less trouble and expense, and gave a larger net profit to the owners than the first. The hands on the two plantations using the hoe were tasked, and gained a portion of each day for themselves; while those on the other place were required to labor during the whole of each day.

A Mr. Waldburg, owning a plantation on St. Catharine's Island, below Savannah, Ga., employed this system of culture exclusively, and became quite wealthy from the profits of his planting interest. $\mathrm{He}$ usually marle two bales of Sea Island Cotton to the hand, with a sufficient amount of Coru to provision them.

When planters wish to use a few plows, they could, by employing twentysix inch Dickson sweeps, and running once in each iniddle, cultivate seventy- 
five acres to the horse, and work over their crop in twelve or fourteen days. This would lighten the work of the hoe hands very much, and wonld require only one-third the number of horses or nules usually emploved. When plows are used the lands should be deeply broker in spring, and the after culture with plow and hoe should be shallow, to prevent injury to the roots of the plant and the consequent shedding of the truit.

A large area of land throughout the Sonthern States is now lying waste and useless, because too low and wet $f^{\prime} r$ cultivation with the plow, but which night be rendered availatle under a system of hoe culture. Thorough draining would be necessary to rid the soil of the superthous water. This might be attained by a set of ditches properly arranged. In the cultivation, the direction of the rows should be stich as to carry the water into these artificial drains.

\section{TO DESTROY BERMUDA GRASS.}

A practical mode of destroying this annoying pest has long been a desideratum in Southern farming. I suggest a plan below which, if faithfully carried out, will, I think, etteetually accomplish the purpose:

Hew ont four pieces of tengh wourl, six feet long and twelve inches square, and mortice three holes in each piece, one and a half inches square; one through the centic, and the other two one and a halt feet froli each end. Have iron bolts or rods made to pass through these holes, with large nuts or keys, in urder to hold the timber securely together. Then mortice holes a half inch wide throngh each piece, in which insert and fasten loug, sharp, wide knives, letting them extend far enough beneath to reach the decpest grass roots. Dub off' onte foot from one of the ends in ordor to make it slide ovir the ground with less difticnlty; and to this end attacly a tongue fir four horses or oxen. The knives should be put in sufficicutly neal each other to ent the grass in pieces not exeeeding an inch in lenisth. They shonld be kept sharp, and the planter should have an extras supply on hand to replace such as may be broken. If the weight of the timbers is not sutiicient to make the knives cut their full length, additional weight should be attached. Two hands will be necessary-one to stand on the slide, and the other to ride and guide the team. A space of three and a halt or fonr feet should be ent, and care shonld be taken not to exceed the latter width, in order that no grass may be left undisturbed.

After the field is passed over in one direction. the slide should go over it again transversely, pains being taken that this direction is exactly opposite the former one. The ground should then be thoronghly harrowed, and the grass gathered in piles and burved. This work should be done in November or early in December.

A suitable harrow may be made of eight pieces of tough wood, four feet long and fumr by six inches square. These should be strungly pinned together, four pieces running each way, and should have forty irou teeth one inch square, one foot long, and square poinied. It should be passed over 
the field three or four times, if neeessary, and should be weighted down the first time. Some sprigs and roots of he grass will be left, but the soil will be so thoroughly pulverized as to enable the winter freezes to kill out what remains.

The driver should walk behind the harrow, and should earry a forked stick, in order to lift and relieve it when choked with grass. All obstructions, such as trees, stumps, logs or roots, should be removed, that the work may be thoroughly done. If the harrow is passed over the field just before planting time again, it will leave the soil in fir:e order for the use of the sweep and sulky eultivator.

\section{A Plan to Economise Time and Labol.}

In the system of cultivation generally pursued, the rows are made to run directly across the field, or in directions eonforming to the $\mathrm{i}$ clination or nature of the ground. On broken or rolling lands this is necessary, in order to prevent the soil from washing away. When lands are level, however, time and labol might be saved by pursuing the plan below suggesterl. If the field is perfeetly square, first remove all obstruetions and break up and harrow the gromnd deeply and thoroughly. Then, with the centre of the side, by which yon enter the field, as a starting point, mark off with a shovel plow the largest eircle possible in the gronnd to be enltirated. This can be done by the use of stakes set at the neeessary points around the borders of the fielul. The eircle shonld be made as nearly perfeet as possihle. When the plowman has nearly arrived at his starting point, the dirertion shonld he changed sufficiently to enable him to run to a stake set seven feet from the starting point, and on a direet line from that point to the centre of the field. Then get a small pole or rod seven feet two or three inches long; attach one end to the bridle bit and the other to a button on the coat or pants of a boy, who will be required to walk steadily in the furrow alrearly made. This will guide the plow in a line lirectly parallel with the eircle first made, and by a continuation of this process the entire field may be "layed off" withont a single stoppage. When the cirele heeomes small, some space in the centre of the field might be left, and this, with the corner: of the field, conld be afterwards sown in Peas.

At the first working of the Corn, if the land is stiff, it should be sided with two seven inch scooters attached to a single stock, one of them running next to the Corn on the right of No. 2, and one plow on the left of $\mathrm{No}$. 1, all the time, till the field is finisher. The middles shonld then be split out with a sulky plow, having five seven inch scooters attached. At all the subsequent plowings side with a twenty or twenty two inch Dickson sweep, and finish the middles with the sulky plow, having three of the above named sweeps attached-two fifteen inches wide, and one twenty-two inehes wide, in rear of them, to finish the middle. If the land is light, the sweeps will answer for all the workings. They will leave the land level and in fine order. Planters shonld he eareful to get the genuine Dickson sweep, as large 
numbers of worthless implements have been sold and used under that name. ()nly three plowings are usually allowed to Corn in the Southern States, but I am confident that a fourth would fully repay for the labor invested. The sulky plow has been condemned by some planters because they failed to side Corn or Cotton properly with them; but in splitting middles, as above lirected, I think they will save the labor of a hand and horse in cultivating wide drilled Corn or Sugar Cane.

If the plan of laying off land in circles, recommended above, is pursued. and if the soil is well prepared and all obstructions removed, a horse will walk twenty miles per day instead of fifteen or sixteen, as they now do. 'This will be a saving of one-fourth the labor, a very important item under the present dispensation, when the expenses of cultivation deduct so largely Irom the profits of the crop.

Southern planters fail to pay sufficient attention to these expedients for cconomising time and labor, being too prone to follow the old-fashioned notions of their fathers. The time is coming, however, when necessity will torce them to abandon these old "landinarks," and, by the use of laborsaving implements and the adoption of a more enlightened system of cultivation, to fall in the wake of the few thinking men, who are now giving a Iresh impetus to the cause of Southern agriculture.

In the plau above suggested, a "turn row" running from the point at which the field is entered to its centre, should be left for the convenience of teams in going from and returning to their work.

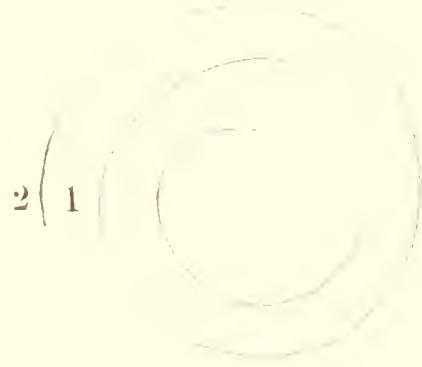

One plow will side the Corn on the right of No. 2, and one plow on the left of No. 1, going round in the same direction till the field is finished. The sulky plow will go outside of the first furrow run; after going round will go in between No. 1 and No. 2, in the same direction, till the field is finished. 


\section{HINTS ON FARM BUILDINGS.}

In "ante-bellum" times, when servants were plentiful and reliable, the Southern planter did not feel the necessity of arranging his farm buildings with any special eye to convenience. As "freedom has come out," however, and we are often forced to the performance of tasks which we have been in the habit of assigning to others, it behooves us to make some changes in the disposition of our dwellings and out-houses, in order to render these tasks as light as possible. The area heretofore allowed has been too large, the distance between the different buildings too great, and they should be contracted to suit the times. In making these changes, however, care should be taken that the danger from fire is not rendered too great. A cooking room or wood-house should never be attached to the dwelling on this account. A corn crib, also, should be detached from other buildings. It should be built on substantial pillars of brick or rock, or on "light wood" or post oak blocks, five or six feet high. These should be covered with tin or copper, and should be capped with pieces of plank of sufficient dimensions to project several inches beyond the post or pillow. These caps should also be lined on the underside with tin or copper. The steps should be made movable, and a supply of corn sbould be taken once a week and put into a smaller crib built on the same plan. These precautions would prevent the depredations of rats or mice, which are becoming a matter of serious importance.

Gin houses should be built thirty-two by forty-two feet "in the clear," in order to allow ten feet for the lint room, and leave thirty-two feet for the diameter of the circle in which the horses turn. When only one story is intended, the sills on which the rafters rest should be eight by twenty inches. The latter should be hewed or sawed three by eight inches, and should be long enough to give the roof considerable pitch. This will give more room. The sleepers should be thin, but very wide, in order that they may not swag. The first story should be at least nine feet from the ground, and the king-post should be sufficiently long to be fastened inside of the gin house. This will make it more steady, and will prevent the swagging of the floor on the king-post. Cog wheels should be made very strong, and should be large enough to give sufficient speed. Wooden cogs are preferable, I think, to iron, as they make the draught lighter and are more easily repaired when broken.

When the soil is very sandy or muddy, or spongy, it would be advisable to make a plank road for the mules, covering it lightly with sand. On very large plantations, the "running gear" should be built with two band wheels, in order that two gins may be used and the crop may be prepared for market as early as possible. The circle will have to be made correspondingly large, so that six mules may be used. Some arrangement should also be made for elevating the cotton to the second and third stories. All gin houses should have a sufficient number of windows, with glass lights, to give thorough ventilation and illumination.

Shingles should be eighteen inches in length, four in width and a half 
inch in thickness, with two-thirds of the length drawn on either side. The bntt ends shoull not be drawu, as they will carry off water morr readily and will be less liable to warp or split if left rough.

An interval of three inches may be left between the sheeting in the Southern States, but in a colder climate, where much snow falls, it should be tongned and grooved, in order to prevent the snow from beating or being blown linou the roof

All gates, except the entranees to a flower garden, should be ten feet wide, for convenience in hauling. There will be very little difference in the expense of building, which will be more than repaid by the lime and labor saved.

The different qualities of eotton should be kept separate, ginued separate and packed in bales separate. If all planters would adopt this rule, there would be less complaint of mixed cotton. It would be better for the planter and commission merchant, and for all men the world over, who deal in cottoll and entton goods.

To run two or more gins, discharging in the same lint room, can lie done by having an additional comntershaft to the gin house, driven by th: drum wheel below. Any machinist will readily understand how to contrive it. By this arrangement six mules will drive two sixty saw gins with more ease than four mules will drive one in th: nsual way. One adilitional feeder only will be required. One hand supplying the enttr n will be quite suflicient, as the gins may be placed conveniently noar to each other. The cotton should be carried into the upper story by lever powe, and a hole made in the flour nearly over each gin, through which a boy might throw the eotton down with a pitehfork, so as to be convenient to each rinner, and economize time and lator.

\section{(:Is'TRNS}

In various sections of the Sonthern States, the water is impregnated with rotten limestone and other ingredients, which exercise an unwholesome infuence on the system and supierinluee lisease. This result might, I think, be avoiled, in a large legree, by the use of eistern. A sufficient supply of water should be outained luring the montle of November. December and January, and should be filtered as it is eaught through charcoal and freestone sand. It will then remain cool during the entire summer. The cistern should be built in September, in a shady grove. if possible, and should have a room fifteen feet square built over it. It slonld be lined with good brick, and on these have a coating of eement. The eost of one holdiug five lundred harrels of water would not exceed fifty dollars in silver. It has been a matter of surprise to me lhat they are not more generally used thrunghout the rotten limestone regions. They are common in Mississippi and Lonisiana, although in some parts of the latter State they have to be built above gromol. I knew a planter in Mississippi who used them on three plantations, and who was so mueh pleased with them that he had one huilt for the use of his family in Virginia. If 
they were more generally adopted in the sections where chill and fever prevail so extensively, "ductors' bills" and empty quinine bottles would not be so frequent. In all regions destitute of water, each citizen should have several cisterus built for the several purposes of drinking, washing, bathing, furuishing varjous kinds of stock, and also for watering garden aud valuable patches around the dwelling. It will pay a householder to buy au engine for this purpose and to extinguish fire. Cisterusare more convenient for extinguishing fires than wells, and are less expensive. The water gathered from the clonds in midwinter is the purest in the world. The value of eisterns has never been appreciated exeept by those who have enjoyed their use. Good, pure cold water in summer is a great luxury and blessing. I consider good cistern water invaluable for all purposes.

\section{ON THE RAISING OF FOWLS.}

A plentiful supply of fresh water at all times is essential to the health of these birds; therefore the enclosure where they are to be kept should always be contiguous to water. The fenee which seeures them should be made of pointed boards, ten feet high. A number of light coops, not too heavy to be easily moved by four men, should be placed about the fowl yard. Their location should be changed and they shon!d be whitewashed within once in every two months. This will have a tendeney to keep the fuwls healthy and free from mites. Should they, nevertheless, become infested with mites, a powder, ealled by the apothecaries the red precipitate, mixed with lard and rubbed under the wings and around the necks, will be certain death to these pests. The fowl yard should have an ample supply of fine gravel for their crops. Sow down small grain, half the yard at a time, every two months, that the fowls may have something green throughont the year. Trees of various kinds should be planted at regular distances, to provide shade and to protect them to sume extent from hawks. Still further, to procure this important result, poles, upon which a number of gourds should be hung to furnish convenient nests for martins, way be placed in each corner of the yard.

Every species of small grain is good for fowls, and fresh meat ehopped fine should be given them once a week. Parched corn, coarsely ground, is excellent to promote laying. Neither Guinea hens, ducks, turkeys, nor geese are likely, in my opinion, to make a profit in the present condition of our section. But the common dunghill fowl, properly teuded, will yicld large profits. The cucks should be changed regularly once a year. 


\section{RAISING HORSES IN THE SOUTH.}

It will pay to raise fine blooded horses only at the South. The Northern and Western farmers can afford to raise horses cheaper than planters in the cotton-growing States. They apply themselves to that business, understand and delight in it, while the Southern planters delight in raising cotton. The Northern lands are very fertile and the elimate much better adapted to raising stock. The one region must therefore supply the other. It has been the case ever since my recollection, and always will be so. Some few planters before the war raised their own stock of all kinds, but they were very energetie, industrious, skillful and intelligent planters, who were able to conduct a complicated business. Since the war, but little stock of any kind has been raised at the South. The planters have to depend on the Northwestern States for horses, mules and meat, and many even for corn and hay, even though they have to pay high prices for them.

Good blooded horses are far superior for saddle and harness. They are fleeter and ean travel longer. Southern planters should raise a few horses, and not depend entirely upon the Northern and Western States. Mules are much preferable for working stock. At the South they stand work better and are less expensive and less subject to disease than horses. They can subsist on joint grass and crop grass pastures, after the crop is laid by and will keep fat on very little eorn. Horses, on the contrary, must be fed daily and curried, or they will beeome very poor.

Good fences have to be maintained to prevent. mules from breaking ont of their pastures, when they are very tronblesome to the owner and to the neighborhood in general. Mules live longer than horses. A mule will do good work at fifteen years of age. When horses commence to fail from age, mules are just in their prime. I have had the management of a great many mules and horses, in different States and various plantations, and for all plantation work prefer mules. I would seleet black mare mules, having short neek, short baek, small legs, and holding the head high. An excellent way to select a good mule or horse from a drove, is to notice those which keep nearest to the drover who leads the drove when upon the road. I ascertained this when traveling with a drove from Woodford County, Kentucky, to Augusta, Ga.

Mules have been greatly improved in size since the year 1830 . They are also now more docile and easier broken to work than formerly. Some few planters object to very lalge mules. If a mule is "put up" well the larger they are the better. A small mule will tire down witl an ordinary load, while a large mule will be traveling with ease. For any kind of work give me a large mule. 


\section{HOG RAISING IN THE SOUTH.}

Hogs require more water than any other stock, as they must bave it not only to drink but to wallow in. The best location then for raising them is on a never failing stream. Next, the planter shoull bave an abundance of open land to be sowed down in small grain, from time to time, during the year. He should cultivate an orebard, and plant yearly a pea patch and root crops, potatoes, chufas, ground peas, beets, carrots and turuips. Cabbage leaves and cialks, and long collards, are useful. All the abovementioned are fine food for hogs. And during the Summer months, erop grass pastures will prove an assistance. Hogs thus fed will thrive much faster than those which run at large in the forests. With proper management these animals can be raised in the Southern States, with the use of but very little corn. The stock minder should pen them every night. Sows and their pigs, and also the shoats, shonld each class have separate pens and should be fed separately. Each pen should have gool pine straw beds and be covered with boards for shelters. At the end of every two months, the manure and straw should be thrown into heaps outside the pens, a small quantity of unslaked lime thrown upon them to facilitate decomposition, and the straw renewed in the pens.

Hogs should be greased once in two months with a mixture of tar, grease and salt. Give them a small portion of this mixture in their corn once a week. It will prevent disease. I never lost hogs from eholera while I pursued this course. Hogs should be earefully marketed at the proper age. Sows that have pigs should be pastured near the dwelling.

Much has been said about hog raising and the different breeds of hogs. Before the war I tried several breeds, but since the war have raised very few of any kind. On the other hand I have lost a great many by theft. Boiled food is excellent for hogs. The foorl should ve thorouglily eooked in large pots, with covers to prevent waste by evaporation. When the food is sufficiently boiled, remove the fires and allow it to grow cold. Boil in the morning and feed at nigbt. Procure long, wide and deep troughs, sufficiently large to hold a quantity, and each animal may secure his share. Then they will lie down quietly in their pens and the food will prove more nutritious. One-third less corn will keep them in much better order than if the whole amount were fed to them raw in the ordinary way.

Hogs will increase very fast if well attended, and a few treated with shill will pay much better than double the number if neglected. A sow should not be allowed to carry more than six pigs, and four wonld be still better. She will raise this number much better, wean them sooner, they will make laiger hogs, while the sow herself will thrive and breed faster.

In boiling food for hogs, a sinall portion of hickory ashes and sulphur should be put into the pot, and also just enough salt to season the mess.

The Chester is a large white hog which can be fattened at any age, and will grow very large if well fed. These will not root for a living. They must be fed and good pastures provided for them.

The large Guinea is a valuable breed and does well when crossed with 
the Berkshire. The best breed of hogs I have ever raised was black, with large body, small, short legs. These suit our climate well, are more healthy, less subject to mange than white hogs, will thrive on less food and not so apt to get into mischief.

IIog raising is a good and paying business if well managed, none better. Should a planter wish to have a large stock to make it profitable, he must have a stock minder to follow the hogs and guard them through the day, and pen them at night. Ile must also have a high picket fence around the hog lot to protect them at night. Such care is absolutely necessary in the Southern States now. The stock minder must devote his time and attention exclusively to his husiness. With a large stock it will pay to hire a man to do this. With only a few hogs they must be pastured near the dwelling house, must be penned at night and noticed closely during the lay. They must be penned on Sundays, and when the master is absent from home. They must be watched elosely in the present condition of the Southern States, and in some sections it is almost impossib!e to raise hogs, or keep them when raised.

The piner wood, long-nosed hog is a very industrious variety of this animal. They can live by rootiug. with but little corn, barely sufficient to make them familiar with the hand that feeds them. They pay better than any other breed in the piney woorls, wire grass and nut grass connties.

\section{CA'TTLE RAISING AT THE SOUTH.}

The Durham and Devon are generally regarded as the most valuable species of imported stock. Both thrive well at the Sontl, after the first year, if liberally fed, but they must he acclimated befure they will thrive. Both species lo well to be crossed with the common stock of the country. Their offspring thrive on less food, and are adapted to the climate. The Derons make the best oxen, as they are more active and docile, and more easily broken to the yoke. They make also the finest mileh cows.

The Durhams are more profitable for beef, as they attain a larger growth. Both specien require to be housed in winter, and are expensive at the Sonth, where neither elover nor blue grass pastures are found. Both species grow to a great size in the Northern and Western States; but it may be questioned whether nur native stock are not better suited, on the whole, to our condition, and, therefore, more profitable. It is true, they are utterly useless and become wretchedly poor in the winter, and some die therefrom every season; but they recover fast when the woods are lurnt off early in the spring and the tender grass shoots forth, and their cost is absolutely nothing to their owners A small stock is more remunerative at the South than a large number. 


\section{S H E E P .}

A few Sheep may prove profitable at the South by the use of rye lots and pastures in the spring, placed near the dwelling house, where they may be watched and guarded from the dogs. They will not prove profitable when allowed to run at large in the woods. In a wire-grass country, thinly inhabited, if the proprietor understood and delighted in his business, Sheep raising on a large scale, for market, would, in all probability, prove very profitable. Then a shepherd must be employed to attend them through the day and to bring thein home at night. Sheep have to be fed during the winter, and field peas and hay are the best food for them. In a cotton country, the erop grass will be found useful. They must be changed frequently from one pasture to another, or they will become unhealthy. Sheep impoverish land more than any other stock, since they eat the grass down even with the surface.

The Merino Sheep have the finest wool, but they are small. The South Down is larger and has fine wool, but not as fine as the Merino. There is but little difference in the value of the two breeds; both make fine, sweet mutton when fat. 'The New Wexford are the largest Sheep, and far the best to be raised for market. Their size is great, the wool long and eoarse, but louble the quantity of the other Sheep. This animal, like all stock, and indeed every business, requires constant attention. Neither stock nor business will prosper, and especially at the South, where provisions are searce and high priced. No food is healthier nor more delicious than good fat mutton. Therefore, every planter shonld have a few for his own use. Were there fewer dogs and more Sheep, the Southern country would be greatly benefitted.

\section{PRODUCTIONS OF GEORGIA.}

No State in the Union, and perhaps no country in the world, possesses so great a variety of soil and climate, and so extensive a capacity for general production, as does the State of Georgia. In addition to all the valuable products grown in the Northern, Eastern, Middle and Southwestern States, Georgia prodnces Long and Short Staple Cotton, Indian Corn, Chicken and Broom Corn, Rice, Millet, Sugar Cane, Chinese Cane, Sweet Potatoes, Irish Potatoes, Chufas, Ground Peas, Field Peas, Beans, IWheat, Rye, Oats, Barley, Buckwlieat, Watermelons, Muskmelons, Cantelopes, Apples, Peaches, Pears, Figs, Pomegranates, Oranges, and all kinds of garden vegetables and herbs. Clover and the Grasses do well in the Middle and Northern sections of the State. Coffee and Cuba Tobiceo might be suecessfully cultivated near the sea coast, if the seed could be procured, and Chewing Tobaceo in the Northern part of the State.

There are also a large variety of smaller fruits and nuts, which either grow spontaneously or can be cultivated with success. Among these are Plums, 
Cherries, Mulberies, Raspberries, Blackberries, Strawberries, Whortleberries, Gooseberries, Wainuts, Hickory Nuts, Peean Nuts, Cbesuuts, Grapes, Musuadines, dc. Considerable quantities of Wine, Brandy, Whisker, Rum, Cider and Lager Beer are made.

Although not strictly a stock-raising state, large numbers of Horses, Mules, Cattle, Hogs, Sheep and (roats might be raised.

Quite a number of mines of Gold, Iron and Copper are being worked, and beds of Lime, Coal and Marl are found in many places. T'ine upper part of the State furnishes a number of fine Sulphur and Chalybeate Springs, and is unsurpassed for healthfulness.

Georgia abonnds in ereeks and rivers, which afford excellent facilities for uannfacturing purposes.

When the railroads now contemplated or in process of completion shall have been finished, they will render every section of the State accessible to travelers and immigrants, and will afford an available ontlet for all the surplus productions, raw and manufactured.

The possesvion of these varied elements of wealth and commercial prosperity-the salubrity and healthfulness of the climate, with the many advantages above enumerated, offer fine inducements to capital seeking investment, or to the immigrant seeking a desirable home. Nothing is needed but the development of these resources to make Georgia one of the finest countries in the world. The devotion of too great an amount of agricultural enterprise and indnstry to the production of Cotton has hitherto served as a drawback on the prosperity of the State. Other specialties receiving the same amount of attention would, I think, often net a larger per cent. of profit to the planter.

The loss of so large a number of practical and experienced farmers by the casualties of the late war has severely crippled the agricultural prosperity of the State, their places being now filled by young and inexperienced men. For the past few years, however, a lively interest has been awakened in regard to the most improved modes of culture, larger amounts of fertilizers have been nserl, anil there is reason to hope that Georgia will soon deserve more than ever before the proud title of "Empire State of the South."

\section{CLEARING LAND.}

In clearing land, the trees should be cut as near the surface of the ground as possible, and all sinall growth should he grubbed up by the roots. The stumps, when low, will decay sooner, draw less nutriment from the soil for their support, and the ground will require less labor in its enltivation. A large amount of shrubbing will be dispensed with, and the crop can be worked more rapidly and with more ease. Tlyere will also be a better "stand," and the crop will suffer less from a droutb. In order to keep land in good heart and to ensure a good yield every year, planters should commence fertilizing as soon as the ground is cleared, instead of waiting, as is usually done; until it has become entirely exhausted. 
Land should be eleared in October and November. The timber and brush to be burnt should be heaped as uniformly as possible, in order to scatter the ashes evenly and over the largest surface. The heaps should be burned soon after a rain, so that the heat may not injure the land, and that the ashes may penetrate the soil more readily. The soil should be broken thoroughly both ways and then harrowed level, to tear the turf in pieces.

New grounds are generally planted too late, and from this eause, combined with imperfect clearing, usually produce but a small yield the first year. If, however, the land is cleared as directed above, and is planted early, the yield will be much more satisfactory. Having tried both methods, I have no hesitancy in saying that the plan of cutting down and burning the large trees and grubbing up all sinall growth will be more economical in the end than to have them girdled, and allow them to die and decay gradually. Some planters contend that the roots and stumps enrich the soil, but $I$ think it poor policy to lose two crops waiting for these to decay.

There is an old adage, and a true oue, that "whatever is worth doing at all is worth doing well," and it is as applicable to clearing land as to anything else. It was always bad policy to have work imperfectly done in time of slavery, and now, when labor is so much more expensive, the policy is worse.

Another advantage of the plan recommended, beside those already alluded to, is, that the crops will receive no injury from the falling of trees during the planting or eultivation. To clear away these obstruetions during the busy season is often a serious inconvenience to planters. Besides, it is sometimes dangerous to labor, in windy weather, in fields where the large trees are left standing. These large trees can be cut off near the ground with more ease by digging holes near their base for the axemen to stand in.

The directions above apply more particularly to oak and hickory land, as on pine land the larger trees are usually reserved for timber for sawing or other purposes.

\section{R O T A T I O N .}

This would be my method in the Southern and Southwestern Cottongrowing States. The first year after elearing, cultivate in Corn and Peas. The second year in Cotton, the third in Corn, the fonrth in small grain, the fiftb in Cotton, the sixth in Corn, the seventh fallow, and so on in rotation. Where there is suffieient open land, half should rest each year. This would ensure good crops and improve the land, and more acres conld be cultivated to the hand and horse. Lands in this section of country cannot be allowed to rest more than one year consecutively, or they will grow up in broom sedge, which will imporerish the soil more than one year's cropping. This grass is not fit for pasture, while it is difficult to plow, and unless broken up in December and harrowed to kill the roots, the land will be difficult to cultivate the ensuing year. If broom sedge fields are broken late in the spring, the land will be so turfy no crop will grow to advantage, while the culture will be difficult to horse and man. 


\section{The Different Species of Lands in the Southern States and their Peculiarities.}

Fertile oak and hickory elay lands, containing a small proportion of sand, are specially adapted to the growth of Cotton, Wheat and Frnits. Good "stands" are more easily obtained on them, and they are less affected by drought than other soils. Grass and weeds are destroyed with less labor, and remunerative yields of almost all crops are more certain. Hoe hands can cultivate more on these lands, but plowing is more laborions for man and holse.

Oak and hickory grey, sandy lands, with clay foundation, are best suited to the production of Corn, Peas, Potatoes, Oats and Rye. Crops grow off and mature earlier on such lands. Cotton stands are generally defective as the plants die out during cold spells in spring. These soils are better adapted to the eultivation of black seed, long staple Cotton than those containing a larger proportion of clay, and more of such lands can be cultivated to the plow.

Red or mulatto pine lands, with clay subsoil, produce good crops of Corn, Cotton, long or short staple; Wheat, Oats, Irish and Sweet Potatoes, Peas, Melons, Orchard Fruits, Tobacco; being, in fact, adapted to almost every production of the Sonth. They are easily cultivated-seldom need drain. ing, and, when situated in healthful and well watered sections, and accessible to towns or railroads, are, I think, the most desirable lands in the Sonthern States.

Light grey pine lands, with clay foundation, will produce fair crops of all the above products, except Wheat and Cotton. They are yenerally very healthful, and on this acconnt as desirable as other kinds possessing greater productive capacity.

River swamps produce finely when planted in Corn and Pumpkins, or Rice. Cotton planted on high beds also succeeds well, if the lands are not subject to overflow. The Dickson's Prolific and Jones' Six Oaks, long staple, are good varieties for such soils. Low lands bordering on these swamps are usually difficult to enltivale, and have to be thoroughly drained and broken. They do well in Corn and Pumpkins, and also in (otton, for two or three year's after being cleared, after which the crop will generally be injured by rust. Creek and branch lands produce good crops in Corn, Oats and Peas, but, like the foregoing, are subject to rust after a few years culti vation in Cutton.

Salt water marshes, reclaimed by dams and drains, are finely adapted to the $\mathrm{gr}^{\mathrm{w}}$ wth of Cabbage, but should remain nncultivated for twelve months, after being drained, in order to allow the salt water to be removed by the rains. The soil should be broken thoroughly three times before planting.

Knolby, broken lands are generally very light, have no forndation, and are not susceptible of much improvement. Their cultivation cannot be attended with much profit. 


\section{1}

Low, wet pine lands, near the coast, and infested with the saw Palmetto, are barren, and, like the last named, profitless when cultivated.

Bay lands, in the lower parts of this and other States, produce good crops of Long Staple Cotton, Upland Rice, Corn, Peas and Potatoes. They are light and spongy, and soon become exhausted. The drains are difficult to keep open on account of the quicksand.

Islands surrounded by salt water have usually a grey, sandy soil, suited to the growth of Corn, Potatoes and Melons, and when fertslized with guano and marsh muck, bring rood crops of Long Staple Cotton. Where the soils have a considerable proportion of clay, the erops of Cotton are much finer, grow longer, and are not so liable to shed fruit. These islands also produce large quantities of Oranges, Lemons, Pomegranates, Figs, \&c.

Mountain lands yield well in Corn and small grain, though they are diffcult to cultivate.

Vall'ys lying between mountains are usually very fertile and healthful, prorlueing fine grain crops. They are also well adapted to the cultivation of Orchard Fruits and to Stock raising.

Rocky lands are adapted to Wheat, Corn, Calbage, Barley, Rye and Oats, and are generally fertile and healthful. The cultivation of such soils involves considerable expense in shoeing stock. When the rocks are so numerous as to interfere unch with the culture of the crops, deep holes should be dug at different spots in the fields, and the rocks should be thrown into them and covered. This will be more economical than hauling them from the field.

Pipe clay lands are usually very unproductive, and cannot be brought to a high condition of fertility without frequent and heavy manurings. The cultivation of these lands is very disagreeable and difficult, as they are too hard in dry weather, and too adhesive in wet seasons. These and crawfish lands pay but a small per centage of profit when cultivated, and I woul.l advise those wishing to invest to avoid these two varieties of soil.

"Cowhide" lands, as they are called by planters in this State, have a thin soil, with a porous subsoil, and are very boggy in the spring. 'They are productive fur two or three years, but are soon exhausted unless fertilized every year. They ran only be improved by being allowed to rest very fre. quently and to grow up in weeds, ummolested by stock.

Beach hammock land are productive in Corn and Peas, but not in Cotton. They have a coarse, sandy soil, are very grassy, and will usually pay best in small grain, or as pastures for stock. They have no foundation, and are difficult to be im proved.

Blue limestone lands in the upper portion of this State are finely adapted to the growth of corn, small grain, clover and grasses, and to strick raising. The water is cold and healthful, being specially beneficial to diseases of the liver, and exercising a contrary effect on pulmonary affections. It is said to agree better with males than females.

Freestone lands in the same section produce fire crops of corn, small grain, peas, beans and Irish potatoes, but are not sc well suited to elover and grasses as the foregoing. The cultivation is less difficult when the land is not rocky, and the water is pleasaut and healthful for all. Prairie lands in Mississippi, Louisiana and Texas are difficult to work, have no rail timber or firewood, and no water that is palatable or wholesome, planters being compelled to use cisterns almost entirely. The crops are very 
uncertain, unless the seasons are very regular, and even then the cotton is frequently severely injured by rust. On the whole I consider such lands undesirable.

Canebrake lands in the same States yield large crops of corn and cotton. The cane is cut down as near the surface as possible, witl long, heavy, steel blades, in the fall, and burned off during a dry time in Spring. Corn or cotton is then planted and cultivated with the hoe. By the close of the first year, the roots are sufficiently decayed to permit the use of the plow, and the land is scootered up both ways in December or January, and afterwards cultivated witlı the plow.

Swamp lands lying near the coasts of the cotton States, when they can be overflown with fresh water, produce good yields of lowland golden rice. When resting they make fine pastures fol stock.

Pond lands, where the lands are stiff, and clay foundation, in the oaky woods, make fine corn, and very prolific, close-bolling cotton. Around the edges cotton will rust. The edges produce fine fall black oats.

Fresh water marshes in North Caroliua produce fine oats and hay; no other crops planted on such lands will pay. Chalk hills, or lands mixed with chalk, will not pay to cultivate.

I would advise all persons desiring to purchase lands in the Southern States to select such as have a good clay subsoil and lie near cities or railroads, in a bealthy, well watered country. Such soils are more susceptible of improvement, and the expenses of transporting a crop to market are comparatively light.

I will give a few more practical hints describing why some lands have the advantages over other lands, that will retain moisture longer and will stand a drought. Pipe clay and crawfish, and cowbide, with thin soil and no subsoil ncar the surface; chalk hills and lands mixed with chalk; high, dry, sandy lands on the sea shore and islands adjacent; and high, dry lands where wells go dry eighty and ninety feet deep; and very broken lands where the elay is on top of the surface, with very thin soil; and very gravelly lands and prairie lands, and sandy luammocks; lands witls no subsoil and woods; ponds that go dry early in Spring that were not thoroughly ditched carly in the fall to keep the water off. All such lands I have above mentioned are very thirsty lands. With deep plowing and fertilized lighly with J)ixon's Compound, and good management, a tair crop can be made. No planter can make a large crop on such lands, if there should come a long drought during the summer months.

Isinglass, river swamp lands, canchrake lands, oak and hickory level lands that have been thoroughly rough drained, with clay subsoil, twelve to fif. teen inches below the surface, and high ridge level lands, situated around large, open, deep ponds, that have not been ditehed, that hold water during summer; and lands situated on branches and creeks, never failing streams during summer, and lands, situated on lakes; and a sandy loam, white or red mulatto land, with clay twelve to fifteen inclses below the surface, that have been fertilized for a number of years, good crops can be made ou such lands, with very little rain, after a stand is procured. I have said there is no rule without exceptions, and it is as applicable to lands as any thing else.

There is a great difference in lands in the Soutbern States in quality and value. Many a man has been deceived in buying lands in the South. I 
traveled with a land speculator for several months. I learned from him and by traveling and eultivating all the different kinds of lands I have above mentioned. If I had not, of course, I would not undertake to deseribe them. Steam plows would pay to break np lands in the Southern States, if all obstruction was removed to economize time and labor and break up the lands more perfectly, and the sooner they are introduced into the South the better for the planter's in the Southern States.

\section{ON BEE HUSBANDRY.}

The following hints on this subject have been furnished by a friend who has been very successful in this department of husbandry, having been engaged in it for forty years.

Three varieties of bees are raised in the South. The Italian, the yellowstriped and the small black bee. The first has the reputation of being the hardiest of the three; though having had no experience with them I can give no opinion as to their merits from personal experience. Of the two kinds last named, the yellow bee is to be preferred, as they are more easily managed and make more and better honey than the other. The black bee is easily irritated, difficult to control and lays up more bee bread than honev. These bees send forth young swarms from the fifteenth of April to the first of June; sometimes twice during that period, at an interval of six or eight weeks between. When this occurs, however, the yield of honey is diminished.

A dry Spring and Summer are most favorable to the production of honey, as wet seasons wash the honey dew from the flowers, and render it thereby difficult for the bees to collect their supplies. Elevated pine lands, with creeks and branches flowing through them, are the best localities for this business. The young swarms should be supplied with hives, made of inch plank, twelve inches wide and three or three and a half feet long. Three small notches shonld be made at the bottom of the hive, in front, for the passage of the bees. The top should be made to slide to afford access for the removal of the worm. Swarms generally collect on a tree or shrub, from which they nay be raked into the hive, aftel being sprinkled with water. The hives should be placed upon an open platform, sheltered above and a space of three feet should be left between them.

The worm is the most formidable enemy to contend with in bee raising. It is about the size of a young wasp, and conceals itself in the corners of the hive, and if not removed will drive out the bees eventually. The slide should be drawn, when they may be taken out with a knife or stick. The platform for the bives shonld be two feet from the ground.

From all the facts which I have gathered in relation to the loss of bees, the greatest loss is sustained, not in the coldest sections, but in those States where the most sudden changes oceur. A colony of bees must have sufficient strength to maintain the requisite heat for their safety. The owner 
must aid them in preserving their numbers, for in strength of number is their security from cold.

When bees are wintered out of doors, many bees are enticed from the hive by the bright sun, in mild and pleasant weather. Soon they become chilled and perish. The cluster by degrees becomes smaller and smaller, and can no longer maintain the requisite temperature when a cold extreme succeeds the pleasant weather. When bees remain in their hives for months the cluster does not decrease, but, on the contrary, is often found to have actually increased by the Spring; for when food and warmth are abuudant, brood rearing commences in December, and numbers of young bees swell the swarm by April.

An early Spring is most favorable to bees. One swarm in a year to each hive is sufficient.

To prevent them from swarming more than once a year: So soon as a swarm issues, remove the parent hive several yards from its place and set a new hive where it formerly stood. The greater part of the matured bees will find their way into the new hive, and that will become very strong, while the old hive will contain few except young bees, and no after swarms will issue. All hives should be well ventilated at the top for the free passage of air and the escape of moisture.

The quantity of honey necessary to the safety of a colony through the winter must vary much with locality and season. No hive should, however, contain less than thirty pounds at the close of the season of production. It is better to allow too much than too little, as the greatest consumption commences in the Spring for brood rearing; and if the supply be scanty, but little brood will be reared until flowers bloom. Where the supply of honey is insufficient, bees should be fed during winter with sugar, and let the supply be so regular as to seem to the bees like their own stores. Feeding should commence when bees first cease to find honey ont of doors, and continued so regularly that they may never want until blossoms open in the Spring. No one should go to the expense of feeding a colony weak in numbers, unless the hive can be kept in some cellar or room where the temperature will remain above the freezing point.

The Italian bee is said to be more hardy than the common varieties. It is also more prolific, and rears more brood under the same circumstances, and thus go into winter quarters with a stronger garrison. Their ability to gather honey from plants which the other bees do not visit, is a great advantage in poor seasons. This is a most profitable pursuit if well managed and in a suitable locality. 


\section{LARGE, DEEP, OPEN PONDS.}

I have said, in one of my chapters, that large, deep, open ponds should never be touched with spade or plow below high water mark. My large experience on this point induces me to write a chapter upon it; and the subject is not without interest, as a considerable portion of the Southern country abounds in these ponds, and the suggestion to drain them is very plausible.

The first plantation I ever owned came into my possession in 1828. in Gordon District, Burke County, Georgia. The district took its name from my uncle, John B. Gordon. It lay in Friar's Pond Settlement, about five miles long and from three to four miles in breadth. About onefourth of the surface is eovered with ponds, forming a perfect chain. About one-third of my plantation was covered with these, with not such fall to drain them, and high ridges lying between them. These ponds I undertook to drain, and for this purpose employed several Greek laborers, several snccessive winters, in ditching. I spent more in reclaiming these lands than the plantation was worth. It proved to be time and money thrown away. One pond having more fall than the rest, I succeeded in draining sufficiently to break up and plant. But found it would produce neither corn nor cotton. When dry, the land was too hard; when wet, too adhesive. In some places the corn and cotton wonld spring up then die, from the sour water soaking in from the higher grounds. The water lying upon it so long had destroyed the productiveness of the soil. I found it would produce nothing but pond grass and water weeds. When left full of water these ponds make fine pastures for stoek during the Spring and Summer months. I am satisfied they were never intended by Providence to be cultivated. Where large, deep, open ponds abound there are no natural water courses, branches or creeks. One pond overflows at the lowest point into another, somewhat lower, in the wet seasons of Winter and Spring. They were designed to supply the wants of cattle, fish and fowls, and to absorb and drain the water from the high ridge lands contiguous to them. They are more valuable for these uses than for culture, in a region five miles square, in other respects destitute of water. Where they are drained the ditches must occupy a considerable portion of better land. And it will prove a burdensome tax to keep such extensive ditches open, and bushes and trees on each side of the ditches grubbed up every year. Many of the stock also fall into these ditches in dry seasons when seeking water, and many perish; some for want of water where the ponds have been drained, and others from falling into the ditches.

It would not pay in the Southern States, where lands are so cheap, to make covered ditches, even in the time of slavery, much less would it pay now.

I sold my place in 1842 to my uncle, John B. Gordon, and in Novernber, 1843, went and took charge of Major W. W. Stark's, Mobly Pond Plantation, in Screven County, Georgia. I had tro plantations to overlook. Major Stark had just finished ditching his Mobly Pond place. The pond 
was seven miles around. The Major spent twenty thousand dollars in ditching that pond. He was very rich and money was no object to him. He had a canal cut through a high ridge of land, lying between the pond and the Savannah river, and emptying in the Savanuah river at a considerable distance. He had a mill house built on this canal, thinking the springs from the pond would always run the mill. But the pond was so thoroughly ditched, when the water began to run, the pond went perfectly dry, and the mill house therefore proved useless.

Cross ditches were cut two feet deep throughout, even the deepest part of the pond delivering their water into the main eaual. This canal was the deepest I ever saw in the whole Southern States. The men had to ereet two scaffolds, one above the other, before they could bring the earth from the bottom of it to the surface. This was done for a considerable distance, and several hands were employed in raking the earth back from the edges of the canal. When the water was let off, persons came for miles around to procure fish, and some of the largest fresh water fish, and no end to quantity, were canght. After the water ran off, the Major undertook to cultivate the soil. Ditehes were dug in every direction, discharging into the canal and railroad tracks laid from the high lands, to bring in soil from the hill sides, and scatter over the surface of the pond. And after all the pains taken and expense, the cultivation woulil not pay. More money was spent on the pond than the plantation could be sold for, and finally the Major had to give it up. The ditehes filled up by eattle crossing them, and in a short time the pond was full of water again.

The high ridge lands produeed better erops before the pond was drained, and the surrounding inhabitants had better health. The pond was so large and deep it seldom went dry, in the driest seasons, before the eanal was cut.

Oak lands, in the vicinity of ponds, produce fine corn, cotton and oats, but are not so well arlapted to the cultivation of wheat and rye. They are hard to cultivate, being generally very stiff, and cotton will rust in their neighborhood. They pay much the best to fence them in for pastures. A pond region is the most disagreeable to reside in. The water is generally very unwholesome, and the residents are generally annoyed by musquitoes, gnats and sand flies, and oy the croaking of frogs at night ; and in the fall they suffer from ehill and fever, bilious fevers and diarrbeas; and all persons, male and female, who reside long in such a region, if they spend their summers there, become subject to enlargement of the liver and spleen, the result of oft-repeated chills and fevers, which oftentimes terminate in dropsies.

In very dry seasons, as for instance, in 1839,1845 and 1866 , most of the ponds go dry and cause a great deal of sickness. I do not wish these remarks to be misapplied to all drainage.

Sinall ponds in the midst of forest growth, and flat, wet lands that become dry early in spring; all such lands should be thoroughly drained, and the water never allowed to remain on them long enough to become sour. The first of September is the proper time to ditch them, and if thoroughly drained, broken deep and early, they will prove highly productive. It is reported that a pond of this kind was, after it was ditched, kept permanently dry by a well forty feet deep, sunk below a quicksand, and which had been dug in the centre of the pond to afford water for the cattle in 
the month of August, 1839. This happened in the Fifth District, Houston County, Georgia.

All persons residing in pond regions should build eisterns. Pond water is very unhealthy, and in many places the wells become stagnant in Summer, and have to be cleaned out frequently and the water drawn off, or they will be full of tadpoles.

Mr. J. W. James, of Burke County, (Georgia, resides within one hundred yards of a large open pond that covers three or four hundred acres. $\mathrm{He}$ has cisterns for his family and for his freedmen. I was at his house in August, 1869, and spent a day and night with him. There was no sickness at that time on the place, not even a single case. I drank some cold, pure water from his cistern, and Mr. James assured me that he had but little sickness since he bad built his cisterns, whilst before he bad a great deal of sickness and lost many of his blacks in slavery. Himself and family also were more or less sick every Spring, Summer and Fall, and even in winter were more subject to diseases, from being so constantly sick during the Summer and Fall. I give the foregoing as my experience in relation to ponds.

\section{O N F E N C E S.}

A straight post and rail fence is the cheapest, strongest and most pleasing to the eve. It will last longer and occupy less space than the Virginia worm fence. Planters in Kentucky generally build these fences where the timber is suitable, and they would prove the best fence in the Southern cotton-growing States. White oak, post oak, sassafras, locust and light wood make the best posts. White, red and Spanish oak, chestnut and long leaf pine are inost suitable for rails. The posts should be dipped in coal tar to the depth inserted into the ground. This will retard decay and keep out wood lice.

The post and rail fences in Kentucky are generally six or seven rails high, the bars from six to ten inches wide. Large trees are cut down and quartered, then split out as for puncheons about two or three inches thick. All the cuts are sawed ten feet and a half in length, and they are lapped three inches at each end where they enter the posts, after dubbing off the thick edges. This makes each panel ten feet long from centre to centre of posts. The posts are laid down and confined upon a platform, then bored out at the proper distances by a two-inch angur. The angur is worked with a long crank and heavy iron wheel, which renders the task of boring much lighter. These holes should be bored and the plugs knocked out before the posts are seasoned. But the posts should be seasoned before they are put in the ground. They will thereby be the lighter to bandle and much more lasting. Hawthorne, Cherokee rose and other plants, sent from the North for live fences, will not answer for the South. Many planters have tested this fact. 'They take too long to grow, occupy too much space, and it is too great a tax to trim them twice a year. In very dry hot summers, like 1839,1845 and 1866 , they die out and are then liable to be consumed by 
fire. I have never seen a live fence at the South so perfect that they could be depended on to keep out stock. Near a city where there is not much stock, a ditch and dam, with short posts and two planks high, would be sufficient to keep them out. Have the soil thrown up high and make the fence on the ditch bank. This would be the cheapest fence that could be devised where timber is scarce, and on low, wet lands the fields would be thoroughly drained by the ditches.

For a live fence at the South I would propose plants thoroughly adapted to our soil and clinnate. As for instance, I would recommend China berries to be sown thick upon the ditch's bank, inside the field and ditch. Sow in the month of April, and in three or four years the young China trees growing up thick would make a good substantial fence. The old field plum tree also treated in the same manner, might be made highly useful as a live fence. Both trees grow fast and upon very poor land. The plum tree, moreover, is thickly covered with thorns. To make a fence the sooner, they might be set out thick upon the bank of the ditch. They are hardy plants, and when set out they wonld grow off rapidly. If they have to be sowed, sow the entire fiuit with the seed.

Clina berries ground fine make a valuable mannre, and are excellent food for stock. The berries ground and nixed with soot is a valuable appli. cation, sown broadcast over a kitchen garden. Besides its value as a fertilizer, it destroys cut worms and bugs. The plums are excellent food for hogs.

The Florida plum is much earlier than those raised in the upper part of Georgia. Near a city, as Angusta, for instance, a planter might cultivate both varieties, and so supply the inarkets with both early and late. Neither plum nor China trees will die out like those plants sent to us from the North at high prices.

The Virginia worm lence takes too much timber and hard labor to construct them, and occupy too much land. Besides, if not built up with care and well braced, they are liable to be blown down, which entails extra labor, and when the growing crop is exposed to destruction from the intrusion of stock. If rails are split from sapling timber, they will last but a very short time. Some planters are in favor of a law to have no fencing. But I prefer a fence and a good fence. Snch a law could never meet with sucess in the Southern States, though it might perhaps be beneficial on the sea islands, surrounded by marshes and rivers. It is difficult to preserve a crop, particularly a provision crop, until it matures, even if well fenced. Near a city it is almost impossible. Not only would a field, unprotected by fence, be damaged by stock, but rognes, white and black, prowling about and doing nothing, would find it still more convenient to make their living by theft.

Many planters, since slavery has been abolished, split their rails from the sapling timber, leaving the large trees and belting them. These injure the crops very seriously the first and second year after they are killed. But the large trees can be split at very trifling expense by the use of gunpowder. To do this, hire a man that understands blasting, and set him to split the cutsopen with gunpowder, and where the trees are very large to split them into quarters. Two men will then very easily split them into rails. These large trees make the best of rails, which will last four times as long as those split from saplings. 
The saplings should be left to grow into large trees, especially where timber is scarce. No country in the world, with but few exceptions, abounds more in timber than the Sonthern States. Yet we constantly bear the cry of no timber raised. Much timber, no doubt, has been wastefully burned which would now possess a high value had it been preserved.

I will now give my opinion as to the best method of removing trees and their stumps, and especially the long leaf pine, from the land. Cut the trees off even with the ground and split then into rails. The fat lightwood will make a fence which will last tifteen years, or perhaps even more. That which will not make rails will make fire and cord wood. Then, about the 1st of September, dig around each stump eighteen inches deep, with a long, broad grubbing hoe, and remove every root to that depth, so that they will never interfere with the plow. Then, with a two inch angur, bore a hole just below the surface, nearly through each stump; if the stumps are very large, bore two holes across each other. Stop these holes with oak plugs, fitting very tightly the augur holes, and bore gimlet boles syadin through these to admit the gunpowder. Fill your holes and surround your stumps with fat lightwood and seasoned wood, mixed; apply a slow match and split open the stumps, when they may be burned out by setting fire to the wood around them.

It would be a great advantage to Southern planters, in the economy of time and labor, to have all such obstructions removed from the action of the plow and hoe. Besides the damage to plows and hoes done by these obstructions, many hills of Corn and Cotton are lost by the space which they fill up; or the stocks are broken down in driving round the stumps, and much time also is lost. The stumps of the long leaf pine never decay. Near a city it might pay to get an improved stump-puller, to take them up and haul them for fuel; but at a distance from city or rail road, it woul.l be cheaper to blow them into pieces with gunpowder and afterward burn them. This can be done in a very short time, and one crop would pay all the expense. When lightwood stumps and trees are very thick in a field, I think I may safely say one-half the time is lost from these obstructions every year. Besides this loss of time, many other disadvantages result. The land cannot be manured to any advantage; the trees and branches fall and seriously damage the crop. In crop time these cannot be removed, so there they lie, increasing still farther the difficulties to eultivate; and when they lie long on the earth they become sobbed, and burn with difficuly $y$ when they finally come to be cleared up. Few planters, I fear, have ever made the calculation, or even given a thought to the losses sustained from these causes. And I have often felt surprised why planters in the Sonthern States did not set themselves to remove these obstructions, especially where the pitch pine abounds. In slavery, loss of time and taking advantage of work were seldom thought of; but now, when latior is so hard to procure and control, it stands every planter in hand to take every advantage of mind and skill, to save time, labor and money. Besides all this, how great is the satisfaction in cultivating a field where there are no obstructions. The work is so much lighter to man and beast. The two horse plow, the sulkey plow, and all other improved implements, could then be used to great advantage in the cultivation of crops. 


\section{Porcelain Clay Hill in Richmond County, Ga.}

There is a fine hill of Porcelain Clay within fifteen miles of Augusta, lying between Pugsley's bridge and Patterson's brilge roads, near to Richmond camp-ground branch. The branch divides the hill. The quantity is inexhaustible, and the quality superior to that found at the Kaolin Mills, on the Hamburg and Charleston Rail Road, S. C. Mr. Roberson, formerly the moulder at these mills, moulded a pitcher for me from this deposit in Richmond county, and pronounced it a superior material to that used at the Kaolin Mills.

\section{ON THE PRODUCTION OF TURPENTINE.}

In North Carolina, those who engage in this business set apart seven hunilred pine trees to exch able-bodied and experienced hand-the number found sufficient to keep him busy until the close of the season in the month of September. They commence in the month of March to box the trees on the south side. After they have finished this work, they shave the bark from each tree to six feet high. Then they go round with buckets, and with seoop remove the virgin dip. Next, with a round shave, they remove the bark four feet higher. Then they go round and remove the Turpentine agrain. After this, they box all the trees on the west side; then remove the Turpentine and again shave off the bark on that side ten feet high, and so on through the season. The wetter the season the better for the production of Turpentine.

The Turpentine collected from Mareh to August is kept apart. That made afterwards, until it becumes too cold for the Turpentine to run, is called second quality, and is kept to itself. Both are then barreled and sent to be distilled. In slavery, an able-bodied hand conld make from two hundred to two hundred and fifty dollars a year at this business. In sections adapted to the business, they usually box and shave the north and east side of the trees the second year, and then those trees are exhausted. But the trees make fine lasting rails or posts. Making Turpentine is a very disagreeable, though healthful, pursuit. Sappy trees of ordinary size, growing on low, wet lands, are most productive. Like all other business, skillful and experienced hands must be employed to make it pay, and these must be overlooked constantly to insure attention to their work. 


\section{RANGING TIMBER.}

During the existenee of slavery this business was extensively followed in the low countries of North and South Carolina and Georgia, and part of Florida. It was then a money-making business. The task for No. 1 hands was three thousand feet per week. In good timher and fine weather, an active hand could finish his task and gain one to two days for himself everr week. I have had two years experience in this business, in checking timber in Savannah for Roberts, Austen \& Co., and I attended to a number of hands cutting timber in Soriven aud Effingham counties, near Savannah, Ga. It is cheaper to hire hands that have been a number of years accustomed to this work, at from twenty to twenty-five dollars a month, than to hire green hands at eight. I proved this to my satisfaction in Scriven county. I had some hands who hall been cutting timber for twenty-five years, and some that had been cutting from two to three year's only. The timber cut by the experienced hands would bring twenty dollars per thonsand, while that eut by the other class would bring only from fourieen to fifteen per thousand. A timber merehant would never offer more than fifteen dollars per thousand for a raft containing these two qualities of timber, mixed; though the best timber in that raft, by itself, would have realily bronght twenty dollars. It is best, therefore, never to mix first, second and third qualities of timber ; it is far better to put each in a raft to itself. An old timber hand, who has followed cutting for a number of years, nine times out of ten can choose good, sound trees by looking at them and striking them with the back of his axe. In knotty trees, where the knots have fallen out, the holes should be tightly plugged with lightwood, which should then be saved off smooth and even with the hewed edge. It w th then pass as good merchantable timber. But if carrierl lown in rafts full of deep holes, the inspeetor and timber merchants will roudemn it, calling it refuse timber, and will only give half price for it. Another advantage in hiring experienced hands is, that their timber is eut so smooth, square and straight, that it will always bring the highest rarket price; for the merchants strive to excel each other, and to buy the best timber in market. A raft of first quality will readily sell in one day after it reaehes Savannah; while a badly hewed raft will lay sometimes six or eight days, two hands being einployed all that time to watch and guard the raft-a great additional expense to the owner. Cutting timber is a healthful and agreealole pursuit, if well managed, and the trees are near a good stream. The hauling is the worst part of it. The longer and larger the trees, the more profitable. Large mules and good drivers are necessary to make it pay. 


\section{GUANO AND FERTILIZERS GENERALLY.}

So many certificates and pamphlets have been distributed among the Southern planters bearing on this subject, since the eonelusion of the war, that it is unnecessary that I should attempt a description of the many fertilizers that are now offered for sale. Every planter has marle up his opinion as to the value of each. The ehemists tell us there is an important difference in the adaptation of manures to r!ifferent soils. I have managed in five Cotton States and visited several Northwestern States, and I think the importance of these distinetions is exaggerated; for I always observed that wherever an old dunghill existed, upon which all refuse matter was east, as far as the influence of that dunghill extended every species of prodnee would thrive, which seems to prove that no such great difference exists. Clay is good manure for sand; and when clay is near the surface, sand is good manure for elay. Many planters grew ricl before the war who never nsed guano at all. Where a man has money idle, no corn nor meat to buy, lives near to a city or rail road, guano, with good management, will pay. But, when a planter has to buy his fertilizers and half his provisions on credit-a con-iderable distance to hanl these; has to sell his cotton, whether the price be up or down, to pay his commission merchant, and a heavy per centage on his loans; then to give the freedmen half the crop, which many have agreed to do thi: year, $(187(1)$, it will not pay.

Planters who roside near to cities or rail roarls should buy stable and other rity manures. They could be shipped by rail road, and would be inuch cheaper than guano, while the cities wonld be much healthier if all kinds of refuse capable of making mauture were cathered from every part of the towns and sent into the country. Such manures could be forwarded in cotton bagging sacks. Pitch the sacks with tar and tallow, and they will he preserved a long period. Planters should make all the manure possible at home; also, all their provisions and but little cotton. This course will pay in the end. Planters who raise everything have fat stock and everything plentiful around them, and a market even at home for everything they have to sell. I have always observed that this class of men lived well, were free from debt, and had but seldom an urgent want of money. On the contrary, those who raised nothing but cotton and had everything to buy on a credit, were generally hard run from one years end to another; had no money they conld eall their own; were always in debt above what they were worth. They lived hard themselves and their hired men also, and their dumb beasts were half starvel; while every year their losses of every kind were im. mense, and every year they tost horses and mules and other stock from bad treatment and improper management. These evils were common before the war, and instead of growing better, things are growing worse every year. I do hope there will be a change for the better from this year forward. Those who will be able to plant next year will be compellerl, in self-defence, to plant more corn, raise more meat, and plant less cotton. The price of cotton would then rise, money and provisions become more plentifial. 
How can a Southern planter make money when be has nearly everything to buy and nothing to sell but low-priced cotton and sorry crops, and ther has to hire hands at a high price? Let us all to a man buy a small piece of land in the right place, on a branch or creek, and near a city or rail road. Let us go to work and improve it, and not depend so wnich on freedmen to make a grand show. How is it that planters in the Northwest make a good living on a few acres? Only because they go to work and improve them.

\section{BESLOW'S COMPOUND.}

Take seven barrels of dry muck or rich soil, two barrels of bon. dust, two of good strong ashes, two of plaster of Paris or Gypsum, and one hundred pounds of salt. Mix these well together. Then dissolve one hundred pounds of Sulphate Ammonia, one hundred pounds Nitrate Soda, and one hundred pounds of Glauber Salts in one hundred gallons of water. With this sprinkle thoroughly the dry mixture. Mix the whole well together; then heap into a compact mass and protect it carefully from sun and rain until called for; then apply it in the manner of guano. The muck must be perfectly dry when the above solution is applied, that it may retain and absorb all the liquid.

The above makes two tons of Beslow's Compound, and all the ingredients cost togrther about $\$ 50$. Several planters have applieri this Compound this year, (1870,) and assert that it will pay as well as any fertilizer they have ever used.

\section{O O K I N G.}

Since freedom was declared and slavery played out, the subject of do mestic service, and especially of Cooks and Cooking, has caused so much anxiety and constant conversation, that $I$ have concluded to write a chapter on the subject myself. In one word, then, I would advise every Sonthern lady to procure a good cooking stove and cook her own food herself. In the fall and winter months, when so many white men and freedmen are walking about doing nothing, hire a good axe hand by the job, to cut a sufficient quantity of stove wood for a year's supply. Let him split, saw to a suitable length, and pile it away in a wood-honse. One good axe hand will cut and pile in this manner a year's supply in much less than a month. Black jack is the best wood, but any kind of oak is good. For kindling any well seasoned wood will answer, but poplar and cotton wood are best-far better for this purpose than pine. Wilh this preparation Southern women can cook for their families with but little toil and annoyance. It will be a little awkward at first, but when accustomed to cooking on at stove it will seem perfectly natural and a light task. Have wood aud water convenient, and suitable houses near to or even attached to the dwelling house, and Southern people will no longer be compelled to bear the insolence and 
extravagance of lired cooks. The wages and other expenses of hiring a cook would almost buy the provisions needed by a small family for a year, not to speat of the aggravations every day in the year, the breakage and waste, meals ont of time and badly prepared. In self-defence, we must eease to have so many of these hirelings abont us. The expense and tronble great-the profit small. If you hire a cook now-a-days, she must have a son or danghter to wait upon her exclusively-an additional expense. No definite calculation ean be made upon her, for she may leave you to-morrow. Then she is unwilling to do any other work, and to earry out her notions, you must hire one or two more to milk, to wash and iron. You never can satisfy any of these in eating; they must have weat three times a day, yet they want grod wages, and paid at the end of every month.

I dislike to dwell upon the sulject, but, to say the least, those who have least to do with them will have most gromod to rejoice, both in this world and the world to come. Southern people must change their schedule. 'They never can prosper' unless they do, and the sooner the better. Let any gentleman or lady take the alternative into serious consideration. How great the contrast when everything is done by neat, cheerful hads at home. Mleals true to time; the victuals well prepared and thoroughly cooked, and therefore, unore nourishing and healthy; fewer to consume, aud, therefore, provisions more choice and abundant. Northern and Western women, who never owned slaves, have been acenstomed from ehildhood to take part in the huusehold work. They are, therefore, not afraid to work, but rather take delight in it. They do all the domestie labor, tend the poultry, the kitchen garden, and a sinall Hower garden, and then, for want of something to do, often assist their male relatives in the field. 'They enjoy fine health, and to see them on the Sabbath days, with bright rosy cheeks, riding their fat horses, with fine sardles and bridles, and dressed in their fine chothes going to chmreh, you would not think they had ever cooked a meal or did any other work in their lives. In one word, where you find those who do their own work there you will find a thriving and plentiful country, a clever, happy and contented people. They live in tine cottage houses and have everything plentiful, convenient and comfortable around the:n.

At the North it is customary to cook enongh at one time to supply the family for several days with the greater part of its food. This makes the labor of cooking much lighter. Cooking three meals every day ought to be abandoned. It canses a great deal of unneessary labor. Cold bread, with hot coffee or tea, is much healthier, and when once aceustomed to it most persous greatly preter it.

I have been urged to recommend a goor cooking stove and washing machine. There are an endless variety of each, and many of them are excellent. Some persons think the Philanthropist Stove surpasses every other. For my own small family I bought a No. 7 Texanna Stove. I can recommend this for a small family. The pots, oven and all the utensils are light, handy and easily kept in order, and it requires but little wood to supply the stove. The stove ean be heated in a very few minntes. My wife generally prepares breakfast in fifteen minutes, dinner in half an hour and heats water for cotfee or tea at supper in ten minntes.

Doty's Washing Machine has been highly recommended by parties at the Sonth, and ean be proenred at I). L. Fullerton's, on Broad street, in Augusta, and in Atlanta, also. 


\section{GENERAL INFORMATION.}

Steel plows are greatly preferable to iron ones; and every planter should either buy them or have them made at home. The plow should be made as light as possible and sharp. It is as needful to have good, sharp, steel plows, to eut the earth, as it is to have a sharp axe to ent down a tree. Steel plows are of much lighter draft than iron. It is also much easier for the plowman to hold them to their proper place. They do their work more perfeetly and leave the land in better order for the next plowing. All plows should eut from point to point, and rmm straight and level. They should be so arranged as to run shallow or deep upon any kind of soil. The solid steel turn plow was invented in Georgia by the Rev. Robert Allen, of Richmond County, Ga., in the year 1816. It was a great improvement, and was ealled the Allen plow, from the inventor.

The planters of Georgia soon laid aside the wooden mould board, and the Allen plow has kept its place to the present day. It is as necessary to success in raising a variety of erops to put the land into good order, as it is to put a horse in good order before he can win a four-mile heat. It is equally necessary to the improvement of erops to plant good improved seed. The improvement should be kept up from year to year, and to seeure that every planter shonld, by all means, have a seed honse exclusively devoted to that purpose. Seaffolds suspended by wires to protect the seed from rats and mice, shonld be constructed in various parts of this house and each scaffold marked with the name of the kind of seed it was designed to cure.

Seed should be dried in the shade and well stirred once every day until dry enough to be packed away in sacks of different sizes, according to the quantity and nature of the seed. Each sack should be markerl with the name and quality of the seed within, and hung up for safe keeping. Al! seed usually required on a farm should be improved and saved. It is a profitable business to save and sell good seed, though somewhat troublesome and requiring very elose attention of the party himself. There is, however, nothing painful or laborious about the business, and every Southern planter could save good seed, and constantly improving for nearly every erop raised by them with only a small expense of care and attention. It would serve their interests well, instead of buying, to have every year seed to sell. Too many planters depend upon buying and begging their seed when, by a little exertion, they might save better seed at home. Very few planters will give away good seed, it is even difficult to buy them. 'To improve their seed and thereby their crops of all kinds, planters should exchange with each other. But giving away good seed must before long entirely cease, in consequence of the many annoyances which attend the bad practice. Sometimes a man will make a small present in expectation of a large one in return, thus hoping to obtain an unfair advantage. I speak from experience. In my judgment, it is better to buy what you need, save what you can, keep atl you have. If you give anything, let it be to the 
needy, and expect nothing in return. Be sure to take care of No. 1. The times have changed, and the people are changed with them.

In the using of plows and wagons, the draught should be near as possible to the horses, yet not to let the swingletrees tonch the horse's heels.

For the same reason, wagons should be coupled closely, unless in a muddy country, then the traces must be longer and the wheels further apart.

Most Southern planters have their plows, earts and wagons, and, indeed all their carriages, too clumsy and heavy. There is no economy in the practice, at the same time it is cruel and unworthy to burden the poor beasts unnecessarily. During the war, and even since, the dumb brutes have been most eruelly treated. They have been givent to man by his Creator, and ther are extremely valuable to him, and all who starve and abuse them will have to give an aceount for it in the day of judgment. It is a shame and a crime for the dumb brutes to be treated as they have been from 1861 to the present time.

No planter in the Sonthern States ean prosper who has everything to buy and nothing to sell in exchange but cotton. It is impossible. It was impossible in slavery, still more impossible now. It is impossible to give the freedmen one-half the erop, as many do, and yet make any elear money, even upon land of first quality and with good management. With bad management and upon seeond quality of land, the planter must fall in debt, as all such will this year, 1870. Let all then who shall be able to farm in 1871 plant all their provisions, and only enough cotton to pay their taxes, and buy salt, coffee, sugar, iron, shoes and elothing. This will be the only safe course for the Southern people.

1 have touched upon the various soils of chief importanee, found in the Southern country, in a previous chapter. Let me here recapitnlate briefly. I have said that red mulatto pine lands, with clay foundations, level, six ol eight miles from a eity, or two from a railroad, on a branch or ereek, and in a healthy section, are the most desirable localities for the settler. The neighborhood of Augusta, Macon or Columbus, Georgia, Columbia, S. C., or Goldsboro, N. C., taking all advantages into consideration, I consider the most desirable in the United States. But land of inferior quality, thirty or forty miles from a eity, or railroad, and poorly supplied with water, to say nothing of buying such land, I would not accept a plantation so situated if I had to live and pay taxes upon it.

I would advise never to buy land in a sickly, snaky, frog pond country. Buy a place near to a eity or a railroad, by all means. A long journey to market, apart from other lisadvantages, will never pay. And if the plan. ter has to buy guano, and one-half of his eorn and meat, one fourth of his time is lost in hauling, and that too, when his stuck should be at home preparing the land for a erop. The stock also will be too much worn with extra work to be in condition to make a full erop, and if the master goes with his teams, all his agricultural interests will suffer during his absenee. 


\section{PLANTING COTTON BY MACHINE.}

I prefer the hoard for covering cotton to any machine, and the dibble is the best instrument for planting. It requires few seed to plant a crop, and all that are left can be applied to fertilize your corn. Cotton seed is the best and surest fertilizer that can be used. It is much better than guano. There is no manure equal to cotion seed for corn and for the garden. Early corn can be greatly improved by fertilizing with cotton seed, and all planters and gardeners should save seed of early corn instead of buying it evers year, as is the habit, at ten cents a piece for a small nubbin. A very high price for seed corn; for it will take three hundred of these nubbins to make a bushel; thirty dollars therefore a bushel instead of saving it at home. I have planted the early Northern corn in Richmond Connty, Georgia, two years. It matured as early as it wonld in Pennsylvania, and as early the second year as the first, and actually improved. The ears are now much larger than those originally planted.

It would serve a good purpose to plant a field of early corn, and also of early peas, every year. Both will bring a high price in market, and the planter would have an extra early field to turn his stock upon. And if he had early corn to sell at five cents an ear, it would bring fifteen dollars a bushel; a money-making business, yet only half the price at which it is sold in the seed stores of our cities.

Southern men should endeavor to save their dimes and half dimes, and in the course of the year they will amount to many dollars. There is more profit in prudent care and economy than in a large proluction. And if ever there is a time to practice these virtues, that time has arrived to the Sonthern people generally.

Red clay and red gravel is the preferable color as a fondation of a soil. Where such a foundation is found, the water is better and the lands generally more productive. I would prefer the soil to be clear of gravel, but. would ever prefer a good red clay foundation. A soil with clay twelve or fourteen inches below the surface will retain manure and moisture, and may thus be rapidly improved. There is a species of fine red sand so closely resembling clay, that one without experience in this matter miglit be easily deceived into the idea that he had a clay foundation where, in reality, there is only a porous sand through which both manure and water will readily make their escape.

To improve the soil steadily and to ensure productive crops yearly, a clay foundation is indispensable. The readiest way to determine whether a subsoil is clay or merely red sand, is to apply a fragment to the tongue, and, if clay, it will adhere closely. Or wet a small portion and breathe upon it, and if clay it will emit a strong odor. Or pour a little alcohol or nitric acid on a fragment when dry, and if it is sand it will crumble and fall to pieces like sand brick. The purchaser should be cautions not to mistake the fine red sand for a red clay foundation.

In the lower counties along the seaboard, throughont the cotton States, where the long moss hangs thick from the oak trees, the atmosphere is 
heary and damp, but highly productive in all erops, decidedly the best lands for either long or short staple cotton, but generally sickly. I have done business in these low and sickly counties, in several States, but experienced much sickness, hald heary doctors' bills to pay and several times to quit business and resort to the blue limestone regions, or the Sulphur Springs, to recover health. None but those who have tried both ean form any idea or estimate of the difference between a healthy and sickly country. Let those who are making a comfortable living in a bealthy region remain where they are, for riches are worthless without good health. I can recommend Richmond County, Ga, in which the city of Augusta is situated, as a fine, healthy region.

\section{CONCLUSION.}

So much has been written by scientific planters at the South of themselves and their achievements, perhaps it may be permitted a plain practical planter to give here a plain narrative of what he has done. When a small boy I plowed for my uncle, John B. Gordon. I superintended for him the feeding of his stoek, the locking up of houses and the other regular daily work of a farm. From that period to the present I have made farming my siudy and delight. I had a llatural talent and fondness for it. In the year 1828 I went on a farm of my own and planted for myself. I usually made from five to six bales of cotton to the hand and abundance of corn, and my stock were generally in good condition. Yet I used no mannes but those furnisher by the plantation, ashes, stable manure and cotton seed. But I had imprudently settled upon a pond plantation, where I had sickness every summer and fall, doctor's hills to pay and waste of property in traveling to recruit $m y$ health. I resolved therefore to sell out, and did so in 1843 . I then went down to Screven County, Ga., and took charge of Major W. W. Stark's plantation, called Mobly" Pond. I remained there from October until the following Jauuary, when I took charge of Major Stark's plantation, below Savannah, on Skidaway Island. I remained there two years, 1844 and I845. I used Peruvian Guano on this place and mud from a salt-water creek. This last application is ad. mirably arlapted to long staple cotton. The plantation was out of order when I came on it-ditcbes, dams and trunks. By Major Stark's orders I attempted the cultivation of cotton with the plow, as I had been aceustomed to do in the up country. It made abuudant weeds. but did not yield as mueh cotton as those crops cultivated entirely with the hoe.

I made a tine erop of corn on Skidaway, so that I had corn to sell to the neighbors.

In the year 1846 I went to Alabama, where I made a fine crcp. In 1847, I went over into Mississippi. near Cbulu River, a prong of the Yazoo. I made there more than the hands eould gather. I fell into bad health, however, and in 1848 went to Kentucky and spent the summer. In November of that year I returned South and spent the winter in New 
Orleans, and afterward in the State, for in January, 1849, I took charge of a sugar estate below Bayou Sara.

In March the levees gave way, the conntry was deluged, and I took a steamboat and left for Savannal once more. There, as I already have said, I was empleyed by Roberts, Austen \& Co., to clieck timber.

In 1850 I entered into an engagement with John S. Green, of Screven County, to superintend a gaug of negroes, who were getting ont ranging timber for the Savannah market. The next year I returned to the scenes of my youth, and took cliarge of two cotton plantations for Elisha Allen, of Burke County. I male him a good crop on each of his plantations. Mr. Allen had agreed to find myself and horse, and to pay me four hundred dollars. At the close of the year he gave me five hundred, saying I had richly earned the difference. I had done a great deal of extra work on both his places.

Afterward, I visited North Carolina, where I managed a cotton plantation a part of the year for a Mr. Wootten, of Lenoir County, ten miles from Guldsboro. Mir. IV. had just commenced the cultivation of cotton, the turpentine business in that part of the State being nearly exhausted. Five hands were retained at the turpentine business, seventy were engaged in making cotton. Mr. Wootten was anxions for me to remain with him. The planters in North Carolına had but little experience in making cotton. They made fine cotton, but planted very little to the hand. They manured their cotton with fresh water muck, oyster shells, lime and salt, and some of the planters prefer that compound to guano.

Cotton seel, I repeat it, is still the best fertilizer fol corn. I prefer it to guano or any other manure that ever has been applied.

After leaving North Carolina, I again returned to Burke, where I man. aged fin Mr. A. J. Lawson, and his son, John F. Liwson, on two aljoining plantations. I made them fine crops of corn and cotton. I attended to all extra work of Judge Lawson's plantation, clearing lanel, ditehing and building houses. During the secund year of my engagement with Judge Lawson and his son I bought the plantation, which I still own. I bonght also four hands, and during the next i wo years made a crop on my own place, thongh I continued to manage for Messis. Liwson. At the end of the fourth year 1 quit business for others and mured home to my own place. I had not plowed now for twenty years, but I now returned to the plow handles. With five other hands and a surry team I made thirty-five bags of cotton, and abundance of corn. I applied stable manure, cotton seed and ashes, but bonght no chemical manures, yet I male fine crops cvery year until the war commenced. After that I planted no more cotton, but went in for log raising, sugar cane, Bnncomle: cabbage, corn and peas.

Since the elose of the war I bave rented ont my place and removed my fanily to Richmond County, a healthy locality. where I expect to remain the residue of my life. Ilid I bought a farm near to Augusta in 1828, and remained at home, I doubt not I wonld have been far richer than I am at present, and would have enjoyed better health, though I would not have acquired the experience which I have obtained by roving. If a man bas a farm in a healthy section, and other advantages of situation, be is very unwise to sell ont and move to a sickly though more fertile country. I have known rich men doing well, in all respects, to sell their prop. 12 
erty and remove to Texas, and in nearly every instanee their wealth soon came to nothing. Nine times ont of ten this happens to the wealthy and prosperous, who make changes to better still more their condition. And in my opinion riches are worthless withont good loalth and contentment. In my travels, I was riding over the comutry, on liorselack, and stopped one rightit at the honse of a gentleman an bayon Black. My entertainer was a Mr. Martin. Ile had been wealthy, and onee owned one of the finest plantations on Nense River, Nortl Carolina. 'There he loarl a liealthy place and well watered, made an abindance of everything and had a good market for everything he wished to sell. Ile possessed good society and every comfort that heart coulu wish; but lie took a notion to move li'est, sold out for what seemed to lim at the lime a full price. Ile first unoved to Alabama. There he soon buried several of his timily. Then he mover to Mississippi, where, in the comse of two years, le lost fifteen of his black and thee of his white fimily. Ile suld ont there at a sacrifice and removed to Texas, where he remained three years and lost several more by death. Ile sold, out here at half price and moved to Lousiama to Bayou Black, a very rich sugar eane region, but lie lost oiler members of his family here, and a few weeks before I risited him his sugar mill was burned. IIe left Nolth Carolina with eighty in family and plenty of money. When I saw bim he had but nireteen black anil white in all. IIe toll me he wonld give laalf the world to lie back upon lis own place on Neuse lives. When I saw him he was perfeclly miserable, and in bad health himself, and alvised me to come back to Georgia and remain.

I have known other rich men to seil ont and remove to Texas to double their wealth, who have lost all their property, and were even too poor to return. Therefore let every one who is prosperons in his home remain and improve his condition there by diligence and economy, and not remove West. For, if the IVest be fertile, it is unhealthy, and even where it is bealthy it is far less agrecable than the favored region which we inhabit. 


\title{
CERTIFICATES.
}

To all whom it may concern:

\author{
Macon, Ga., October 18, 1870.
}

I was the purchaser of 27,000 melons in Richmond County, at Angusta, Ga., and the finest of the lot were those I purchased trom Mr. E. P. Godley, 220, early in the month of July. They averaged forty-two pounds and sereral weigling sixty pounds. For sweetness, color and thinness of rind, they were superior to all others, and netted one dollar a piece.

TH. W. BUFFUETTE.

\section{Georgra, Burke Countr, September 4, 1858.}

To all whom it may concern:

I have known E. P. Godley from his infancy to the present hour. He has followed plantiag for a living all his life. It has fallen to the lot of few men to enjoy the advantages which he has, or to reap the vast experience which he possesses. He has attended to unsiness in North Carolina, Georgia, Alabama, Lonisiana and Mississippi, and has invariably given entire satisfaction. He has lived with me the past four years, and I can say that be is industrious, energetic and skillful in the management of a crop and plantation, surpassing any man I liave ever known. Consequently I most cheerfully and confidently recommend him to any or all who may wish a man to attend to a large and intricate business.

\section{A. J. LAWSON.}

\section{Georgia, 'натнам County, December 20, 1845.}

Mr. E. P. Godley has attended to my two plantations at Mobley's Pond, Sereven Corinty, Gra; also, he managed my business on Skidaway Island, two years, 1844 and 1845 . He is an honest, industrious man, and a good manager, a good planter and a sober, reliable man.

WIATTE W. STARK.

State of Georgin, Burke County, October 5, 1843.

We, the undersigned, take great pleasure in stating that we have been acquainted with Mr. Elypsey P. Godley from his infancy up to the present time, and we cordially recommend him to any and all who wish to employ him as an bonest, industrious man, and a most excellent planter.

A. J. LAWSON,

A. G. FRYER,

ALLEN BOYT,

JOHN B. GORDON,

MCAMACK NORRILL,

JAMES M. REYNOLDS, EZEKIEL WILLIAMS,

Z. L. F. TAMBERLIN,

C. F. FICKLIN. 



\section{E R R A $\mathrm{T} A$.}

PAGE 41.-Second line from bottom for three bushels stable manure read three loads.

PAGE 77.-Seventh line from top for .J. W. James read .T. V. Jones. 

$=929121$

\section{PRACTICAL}

FARMER'S GUIDE WRITTEN BY

\section{E. P. GODLEY.}

OF BURKE COUNTY, GA.

REVISED BY

HON. WALtER A. CLARK, OF RICHMOND COUNTY.

AUGUSTA, GA.

JAS. L. GOW, BOOK AND JOB PRINTER.

1871. 








\section{mus

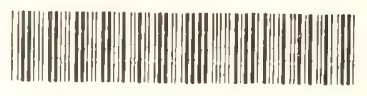 믈? 3 35 2ᄅ}

W.1.

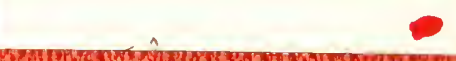

1.th 2.12

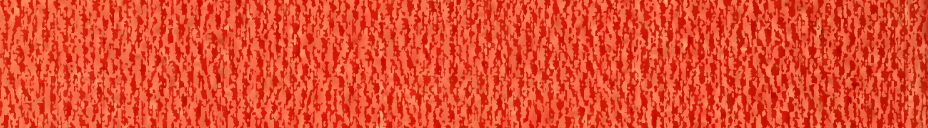
3.

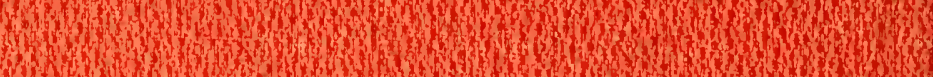

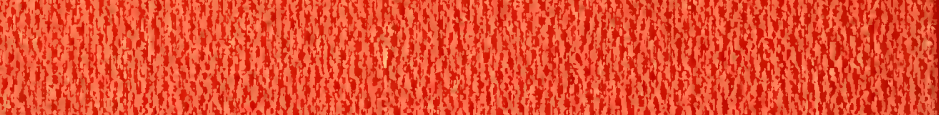
-3)

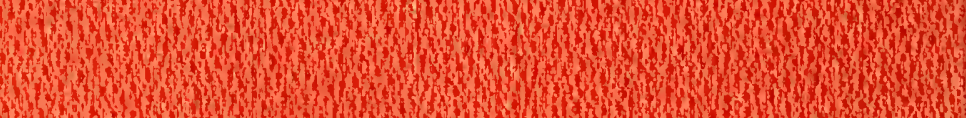

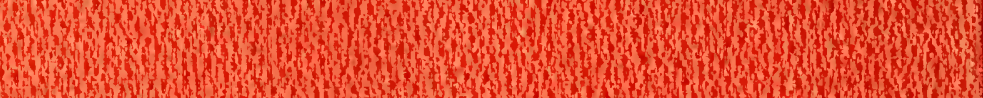

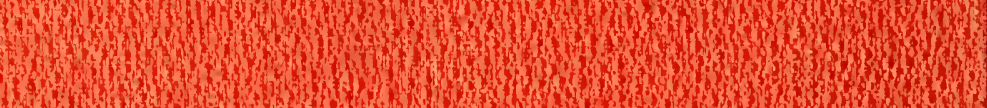
1.7. 13.

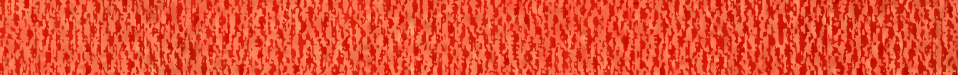

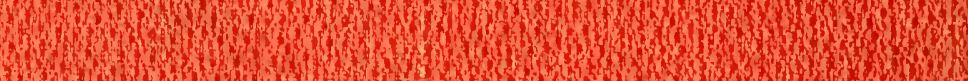
Hith

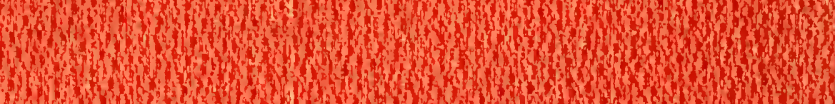
W.

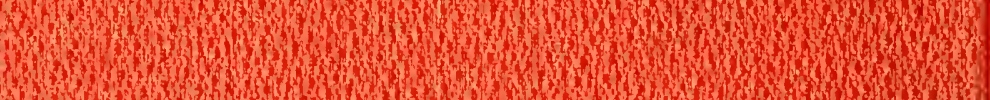

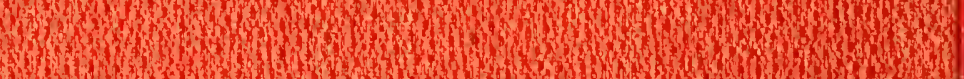

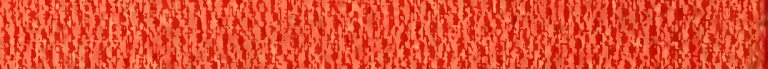

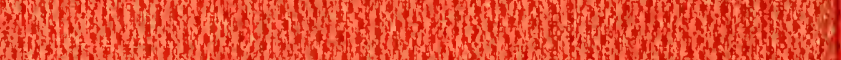

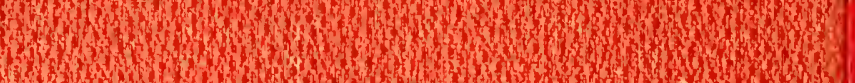
3 13)

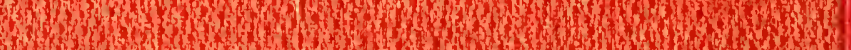

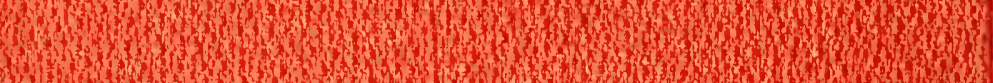

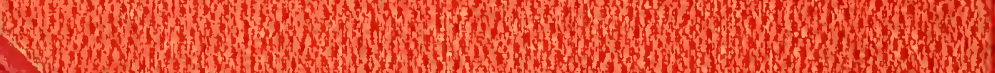
4.3. 